\title{
TRANSFERÊNCIA TRANSIENTE DE GENES EM EMBRIÕES DE GALINHA POR MEIO DA BIOLÍSTICA
}

\section{LUCIANA DE ANDREA RiBEIRO Bióloga}

Orientador: Prof. Dr. JOÃO LÚCIO DE AZEVEDO

Tese apresentada à Escola Superior de Agricultura "Luiz de Queiroz", Universidade de São Paulo, para obtenção do título de Doutor em Agronomia, Área de Concentração: Genética e Melhoramento de Plantas.

P I R A C I C A B A

Estado de São Paulo - Brasil

Julho - 1999 


\section{Dados Internacionais de Catalogaçāo na Publicaçāo (CIP) DIVISĀO DE BIBLIOTECA E DOCUMENTAÇÃo - Campus "Luiz de Queiroz"/USP}

Ribeiro, Luciana de Andrea

Transferência translente de genes em embriōes de galinha POR MEIO da biolistica / Luciana de Andrea Ribeiro. - Piracicaba, 1999.

$99 \mathrm{p}$.

Tese (doutorado) - E Escola Superior de Agricultura Luiz de Queiroz, 1999.

Blbllografia.

1. Blollstlca 2. DNA 3. Embrião animal transgênico 4. Galinha 5. Melhoramento genético animal 6. Transformaçăo genética I. Titulo 
Aos meus pais,

Feliciano Ribeiro e Maria Aparecida de Andrea Ribeiro

pelo apoio, incentivo e dedicação:

\section{DEDICO}

Aos meus irmãos, Cláudia e Raphael e à minha sobrinha, Karoline

pelo carinho e momentos alegres: 


\section{AGRADECIMENTOS}

- Ao Prof. Dr. Luiz Lehmann Coutinho pela amizade, orientação e possibilidade de realização deste trabalho no Laboratório de Biotecnologia Animal.

- Ao Prof. Dr. João Lúcio de Azevedo pela viabilização do meu doutorado, incentivo e apoio.

- Ao meu grande amigo Luís Cláudio Prado pela eterna amizade, companheirismo, estímulo e apoio fundamental para a realização deste trabalho.

- À Vera pelos ensinamentos, dedicação, paciência e grandiosa ajuda durante todo o meu doutorado.

- Às minhas amigas de república Elaine e Kika pelo carinho, apoio e paciência.

- À minha amiga Solange pela amizade, carinho e imensurável ajuda na redação deste trabalho.

- À Pilar, Helena e Elaine pela valiosa ajuda durante os bombardeamentos.

- À Jane e a Lúcia pelas sugestões e ajuda durante toda a realização deste trabalho.

- À Cristina pela amizade, apoio e dedicação.

- Ao Adilson e, novamente, à Jane pelo apoio, incentivo e estímulo durante todo o meu doutorado.

- Aos meus amigos Gilberto (Kazuo), Nelson, Derly, Dorinha, Cláudio, Heyder, Leonardo, Luciana Rodrigues, Rogério, Dario, Francisco (Chico), Marcelo (Baba), Josué e Chirlei pela amizade, carinho e momentos de alegrias. 
- Ao pessoal do Laboratório de Biotecnologia Animal: Adilson, Cristina, Jane, Nirlei, Pilar, Helena, Lúcia, Érica, Elaine, Cláudia, Humberto, Jorge, Andrea, Rodrigo, Kalinca, Tuka e Sofia pelo apoio e ajuda durante todo o meu doutorado.

- Aos colegas do curso de pós-graduação em Genética e Melhoramento de Plantas do Departamento de Genética da ESALQ/USP pela amizade e companheirismo.

- Aos professores e funcionários do Departamento de Genética e Zootecnia da ESALQ/USP pelos ensinamentos, presteza e atenção dispensada.

- Às funcionárias da biblioteca do Departamento de Genética da ESALQ/USP pela dedicação e ajuda.

- Aos pesquisadores Elíbio Rech e Francisco Aragão pelos ensinamentos e valiosas sugestões na elaboração destes trabalho e dos artigos relacionados.

- À Fundação de Amparo à Pesquisa no Estado de São Paulo (FAPESP) e EMBRAPA/CNPSA pelo apoio financeiro.

- À todos que contribuíram para a realização deste trabalho. 


\section{SUMÁRIO}

Página

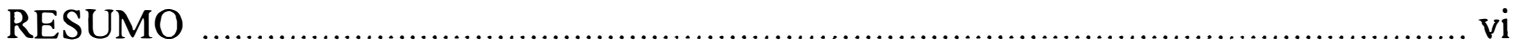

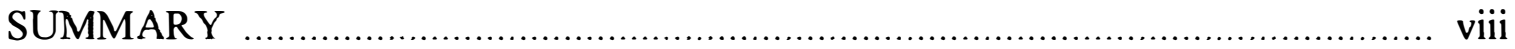

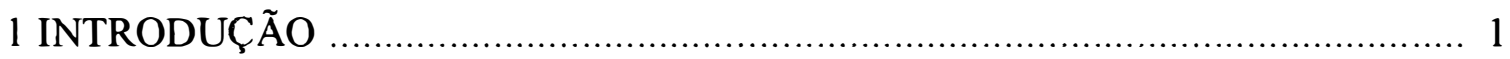

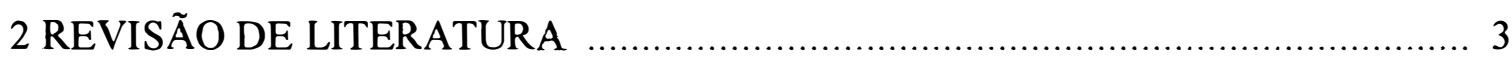

2.1 TÉCNICAS DE TRANSFERÊNCIA DE GENES EM ANIMAIS ................... 3

2.2 PRINCÍPIOS BÁSICOS DA BIOLÍSTICA ...........................................

2.2.1 ACELERADOR DE MICROPARTÍCULAS ........................................ 17

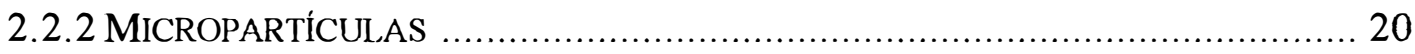

2.2.2.1 Tamanho das Partículas ................................................ 21

2.2.2.2 Precipitação do DNA sobre as Micropartículas ........................ 21

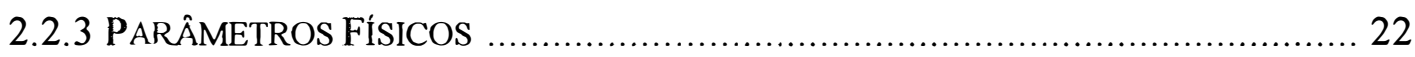

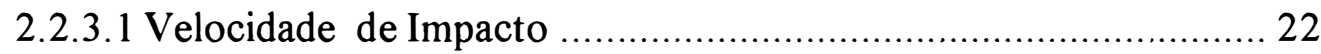

2.2.3.2 Vácuo/Gás Residual ....................................................... 24

2.2.3.3 Onda de Choque/ Choque Acústico ...................................... 25

2.2.4 PARÂMETROS BIOLÓGICOS ........................................................ 26

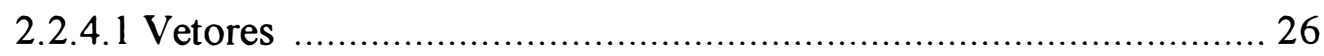

2.2.4.2 Fisiologia e Idade das Células ..................................... 27

2.2.4.3 Tamanho das Células .................................................... 27

2.2.4.4 Densidade Celular ........................................................ 27

2.2.4.5 Tratamento Pré e Pós Bombardeamento ................................. 28

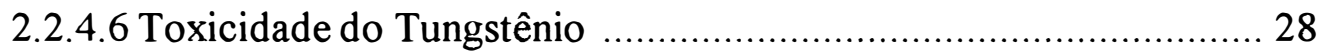

2.3 TRANSFERÊNCIA DE GENES EM CÉLULAS E TECIDOS ANIMAIS POR MEIO DA

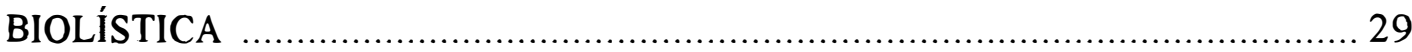

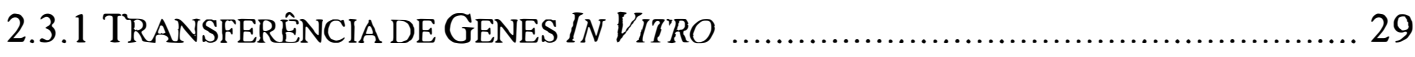

2.3.2 TRANSFERÊNCIA DE GENES IN VIVO ............................................... 31

2.3.3 TRANSFERÊNCIA DE GENES EMOVOS E EMBRIÕES ........................... 33

2.3.4 TRANSFERÊNCIA DE GENE EM INVERTEBRADOS ............................ 34

2.3.5 TRANSFERÊNCIA DE GENES EM EMBRIÕES DE GALINHAS IN OVO ............... 34 
3. CAP.I: TRANSFERÊNCIA DE DNA IN SITU EM EMBRIÕES DE GALINHA POR MEIO

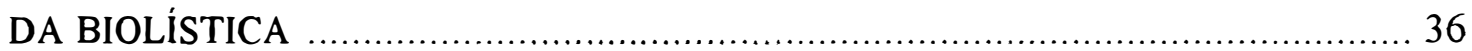

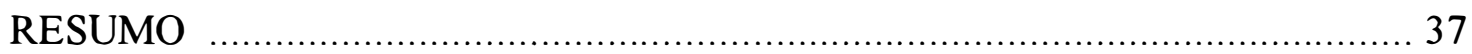

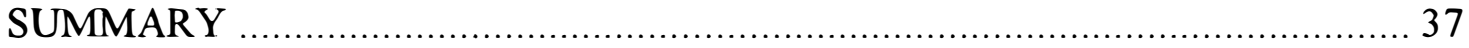

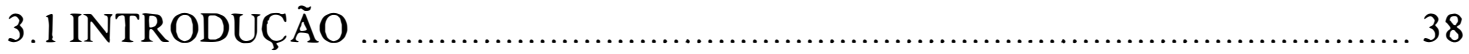

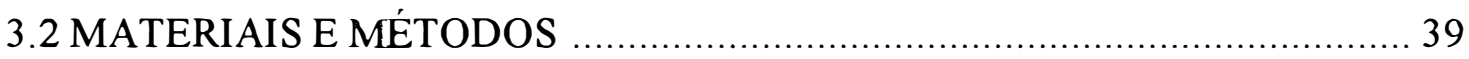

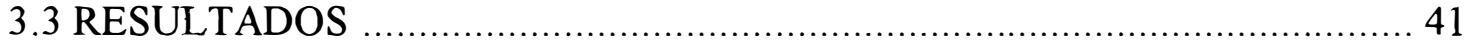

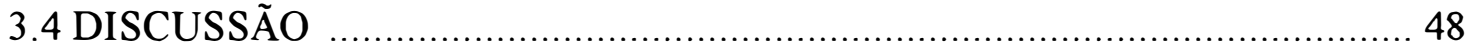

4. CAP II: TRANSFERÊNCIA DE GENES IN VITRO EM EMBRIÕES DE GALINHA POR

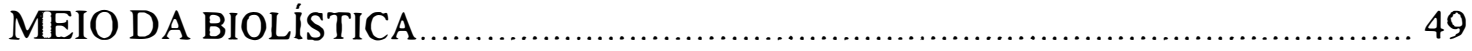

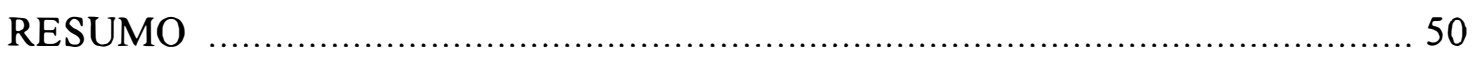

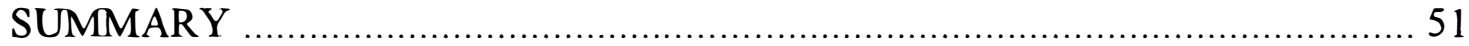

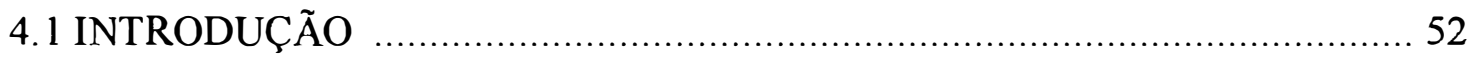

4.2 MATERIAIS E MÉTODOS ……................................................................ 53

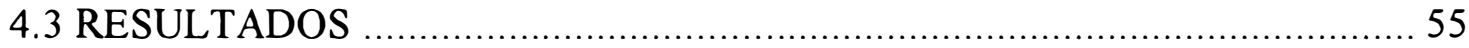

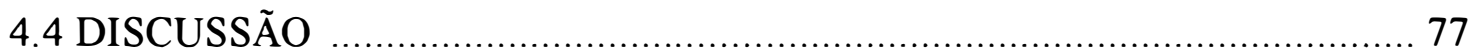

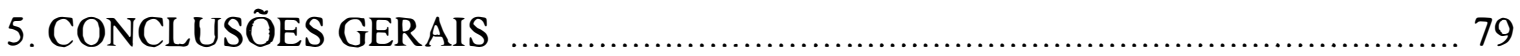

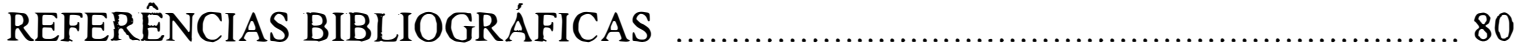




\title{
TRANSFERÊNCIA TRANSIENTE DE GENES EM EMBRIÕES DE GALINHA POR MEIO DA BIOLÍSTICA
}

\author{
Autora: LUCIANA DE ANDREA RIBEIRO \\ Orientador: Prof. Dr. JOÃO LÚCIO DE AZEVEDO
}

\section{RESUMO}

A biolística é um método fisico para a introdução de ácidos nucleicos e outras moléculas no interior de células e tecidos, devido à aceleração de micropartículas a altas velocidades. Esta técnica tem sido amplamente utilizada para a transferência de genes, em uma variedade de espécies animais, devido a alguns fatores como: baixa manipulação do alvo a ser bombardeado, simplicidade e rapidez no processo de bombardeamento, liberação de altas doses de DNA em alvos específicos, bombardeamento simultâneo de muitas células e possibilidade de co-transformação com dois ou mais plasmídeos.

Este trabalho descreve o desenvolvimento e a otimização da biolística para a transferência de genes em embriões de galinha. Diferentes condições de bombardeamento foram testadas, visando a obtenção de altas taxas de transformação, máximo número de células transformadas e reduzido dano ao tocido bombardeado. Os parâmetros avaliados foram: tipo e tamanho das micropartículas, distância percorrida pelo DNA-micropartículas até o embrião, posicionamento dos embriões em relação ao centro do cone de dispersão das partículas, pressão de gás hélio e nível de vácuo na câmara de bombardeamento.

As condições de bombardeamento foram otimizadas para a transformação de embriões de galinha, dentro do próprio ovo (bombardeamento in situ) ou cultivados em meio de cultura (bombardeamento in vitro). As condições ótimas para o bombardeamento in situ foram obtidas com: partículas de ouro de 1,5 a 3,0 $\mu \mathrm{m}$ de diâmetro, distância de 11 
cm percorrida pelo DNA-micropartículas até o embrião, posicionamento dos embriões a 1 $\mathrm{cm}$ de distância do centro do cone de dispersão das partículas, 600 psi de gás hélio e 600 $\mathrm{mmHg}$ de vácuo. Sob estas condições, a eficiência de transformação e a taxa de sobrevivência foram, $68,7 \%$ e $31,2 \%$, respectivamente. No bombardeamento in vitro, as condições ótimas foram: partículas de ouro de 1,5 a 3,0 $\mu \mathrm{m}$ de diâmetro, distância de $8 \mathrm{~cm}$ percorrida pelo DNA-micropartículas até o embrião, posicionamento dos embriões a 0,5 $\mathrm{cm}$ de distância do centro do cone de dispersão das partículas, 800 psi de gás hélio e 500 mmHg de vácuo. A eficiência de transformação e a taxa de sobrevivência foram 98,5\% e $25,4 \%$, respectivamente. Estes resultados demonstraram a viabilidade da biolistica para a introdução de genes exógenos em embriões de galinha. 


\title{
TRANSIENT GENE TRANSFER TO CHICKEN EMBRYOS BY BIOLISTICS
}

\author{
Author: LUCIANA DE ANDREA RIBEIRO \\ Adviser: Prof. Dr. JOÃo LÚCIO DE AZEvEDO
}

\section{SUMMARY}

Biolistics is a physical method to introduce nucleic acids and other molecules into cells or tissues through highly accelerated microparticles. This method has been widely used as a means of gene transfer in various animal species due to some of its characteristics which include reduced manipulation of the target, simplicity and speed of the bombardment procedure, ability to release high doses of DNA to specific targets, possibility of simultaneously bombarding many cells, and the possibility of carrying out co-transformation with two or more plasmids.

This work describes the development and optimization of the biolistic process for gene transfer to the chicken embryo. Different bombardment conditions were tested, aiming to obtain high transformation rate, maximum number of transformed cells, and reduced damage to bombarded tissue. The parameters evaluated were: microparticle type and size, DNA-coated microparticle flying distance to the embryo, position of the target in relation to the center of particle dispersion cone, helium gas pressure, and vacuum within the bombardment chamber.

Bombardment conditions were optimized for the transformation of chicken embryos that were kept either in the eggs (in situ bombardment), or in culture medium (in vitro bombardment). Optimal in situ bombardment conditions were as follows: gold particles with diameter ranging from 1.5 to $3.0 \mu \mathrm{m}$, DNA-coated 
microparticle flying distance to the embryo of $11 \mathrm{~cm}$, embryo placed at $1 \mathrm{~cm}$ from the center of the particle dispersion cone, $600 \mathrm{psi}$ helium gas pressure, and $600 \mathrm{mmHg}$ vacuum pressure. Under these conditions, transformation efficiency and survival rate values were $68.7 \%$ and $31.2 \%$, respectively. For in vitro bombardment, the optimal conditions were: gold particles with diameter ranging from 1.5 to $3.0 \mu \mathrm{m}$, DNA-coated microparticle flying distance to the embryo of $8 \mathrm{~cm}$, embryo placed at $0.5 \mathrm{~cm}$ from the center of the particle dispersion cone, 800 psi helium gas pressure, and $500 \mathrm{mmHg}$ vacuum pressure. Transformation efficiency and survival rate values were $98.5 \%$ and $25.4 \%$, respectively. These results show that the biolistic process is a viable and efficient method for exogenous gene transfer to the chicken embryo. 


\section{INTRODUÇÃO}

A biologia molecular vem proporcionando avanços significativos no estudo dos mecanismos básicos envolvidos na expressão e regulação gênica, assim como, na descoberta de novos genes. No entanto, ainda ocorrem limitações para aplicações práticas, como por exemplo, o desenvolvimento de espécies animais melhoradas por engenharia genética, devido a dificuldade de se transferir eficientemente genes economicamente importantes. A introdução de genes em células, tecidos ou órgãos depende da disponibilidade de sistemas confiáveis e eficientes de transferência de genes de interesse.

Várias técnicas de transferência de DNA, em animais, têm sido desenvolvidas. Em aves, infeç̧ão por retrovírus tem sido utilizada com sucesso em células somáticas e germinativas, devido às altas taxas de transfeç̧ão obtidas. Entretanto, este procedimento apresenta algumas desvantagens que limitam o seu uso, tais como: o tamanho limitado do transgene a ser introduzido, as complexidades envolvidas na produção de vetores virais deficientes em replicação, a pequena aceitação pública e o risco de gerar recombinantes com vírus do tipo selvagem. Outras técnicas não virais, como: microinjeção de DNA em ovos recém fertilizados, lipofeç̧ão, eletroporação e biolística têm sido desenvolvidas e aplicadas em embriões de galinha, mostrando-se viáveis e úteis para a transferência de genes.

A biolística tem sido recentemente utilizada para a transferência de genes em embriões de galinha. As vantagens desta técnica são: rapidez, simplicidade, capacidade de liberar altas doses de DNA em alvos específicos, manipulação mínima do material a ser estudado, bombardeamento simultâneo de muitas células e possibilidade de co-transformação com dois ou mais plasmídeos. Neste sistema, micropartículas de ouro ou tungstênio, 
conduzindo DNA adsorvido, são aceleradas em alta velocidade para penetrar nas células ou tecidos, introduzindo assim o DNA de forma não letal. Diversos aparelhos foram desenvolvidos para este fim, aplicando o conceito básico de uma onda de choque, que acelera um macrocarreador, contendo as partículas. No entanto, para assegurar a eficiência de liberação de DNA dentro da célula e diminuir os efeitos prejudiciais, faz-se necessário otimizar algumas variáveis da técnica, em função do tipo de célula alvo a ser bombardeado.

Este trabalho descreve o desenvolvimento e a otimização de duas formas de transferência transiente de genes em embriões de galinha, por meio da biolística: bombardeamento de embriões dentro do próprio ovo (bombardeamento in situ) e de embriões cultivados em meio de cultura (bombardeamento in vitro). Diversas variáveis intrínsecas da biolística foram analisadas, como: tipo de partícula (tungstênio ou ouro), tamanho das partículas, pressão de gás hélio, nível de vácuo na câmara de bombardeamento, distância entre a membrana carreadora e o embrião, posicionamento do embrião em relação ao centro do cone de dispersão das partículas e profundidade e área de expressão do gene repórter introduzido.

Para atingir tais objetivos foram apresentados dois trabalhos, os quais são:

- Transferência de DNA in situ em embriões de galinha por meio da biolística.

- Transferência de genes in vitro em embriões de galinha por meio da biolística. 


\section{REVISÃO DE LITERATURA}

\subsection{TÉCNICAS DE TRANSFERÊNCIA DE GENES EM ANIMAIS}

O desenvolvimento de técnicas de introdução de genes em células somáticas e germinativas de animais de laboratório e animais domésticos, foi um dos principais avanços tecnológicos ocorridos nas últimas duas décadas. Animais geneticamente manipulados têm fornecido novos modelos de estudos da regulação gênica, da ação de oncogenes e das interações celulares envolvidas no sistema imune. Além disto, a tecnologia de transgênese animal possibilita a geração de modelos animais precisos para estudo de doenças genéticas humanas e a produção, em larga escala, de proteínas recombinantes de interesse farmacológico humano (Jaenisch, 1988; Pursel \& Rexroad, 1993 e Wall, 1996). Uma outra aplicação, para um futuro próximo, é a produção de animais transgênicos (freqüentemente suínos), que expressem fatores imunes à rejeição, servindo como doadores de órgãos para transplante em humanos (xenotransplante) (Lanza et al., 1997). Entretanto, a utilização de animais transgênicos para a produção de alimentos, permanece pouco explorada. Isto decorre devido ao reduzido número de genes de interesse para a agropecuária, que já tenham sido identificados, isolados, seqüenciados e clonados (Pursel \& Rexroad, 1993).

Animais transgênicos podem ser definidos como aqueles que contém moléculas de DNA exógeno, introduzidas por intervenção humana intencional, objetivando a expressão de novas características (Wall, 1996). Por analogia, o gene transferido, denomina-se transgene (Pursel \& Rexroad, 1993). Entretanto, a integração 
por si só não garante a expressão do transgene, e, uma outra definição seria, aquele animal que expressa o transgene e que quando acasalado com animais normais, produz progênies que herdarão este gene de forma mendeliana, devido a incorporação do transgene nas células germinativas (Gordon \& Ruddle, 1981).

$\mathrm{O}$ primeiro experimento com transgênese animal foi realizado com células da linhagem germinativa de camundongos, em 1974. O genoma inteiro do vírus Simian foi microinjetado, na cavidade blastocélica de embriões em estádio inicial do desenvolvimento (Jaenisch \& Mintz, 1974). Entretanto, a integração de DNA viral só foi detectada, em estudos subsequentes, quando embriões de camundongos foram microinjetados com o retrovírus da leucemia de Moloney, gerando a primeira linhagem de camundongos transgênicos (Jaenisch, 1977). A partir dessa data, vários protocolos tem sido desenvolvidos, buscando-se alterar o genótipo de animais de maneira estável.

A expressão do DNA exógeno introduzido, por sua vez, foi obtida também em camundongos, no início da década de 80 (Gordon \& Ruddle, 1981 e Palmiter et al., 1982, 1983). Camundongos gigantes, gerados a partir da introdução do transgene (promotor da metalotioneína de camundongos e gene do hormônio do crescimento humano) em embriões de uma única célula, demonstraram que a integração foi estável e a expressão foi correta nos tecidos do animal adulto (Palmiter et al., 1983). Estes resultados incentivaram a especulação, sobre a aplicação das técnicas de transgênese para aumentar o crescimento em espécies domésticas.

Coelhos, ovelhas e porcos transgênicos foram obtidos, em meados da década de 80 (Hammer et al., 1985) e bovinos e caprinos, no início dos anos 90 (Pursel \& Rexroad, 1993). Entretanto, a eficiência de transformação obtida foi bem menor que a obtida em camundongos.

Várias técnicas têm sido utilizadas para a introdução de genes tanto em células germinativas quanto em células somáticas de várias espécies de animais. Entre eles incluem: a) microinjeção de DNA em pronúcleo, b) infecção por retrovírus, c) células embrionárias indiferenciadas ("embryonic stem cells"), d) espermatozóides como vetores, e) eletroporação, f) co-precipitação com fosfato de cálcio, g) lipossomos, h) 
lipofecção, i) transfeç̧ão de DNA mediada por dextran DEAE, j) transfecção de DNA mediada por polibrene, k) método utilizando laser, l) injeção direta intramuscular de DNA, m) transferência de células da blastoderme transfectadas, n) transferência de células germinativas primordiais transfectadas e o) biolistica.

Dependendo da técnica utilizada, o animal produzido pode constituir-se totalmente de células que carregam o transgene (são os denominados animais transgênicos) ou de conjunto de células que carregam ou não o transgene (animais quiméricos ou mosáicos). Os animais quiméricos são constituídos de células de origens distintas, enquanto que, os mosáicos são constituídos de células derivadas de um único blastocisto original. As técnicas que envolvem a introdução de células transformadas em um embrião receptor (por exemplo, a transfecção de células embrionárias indiferenciadas e, posterior, introdução destas células em embriões em estádio de blastocisto) darão origem a animais quiméricos. Por outro lado, técnicas que transfectam diretamente as células do animal a ser transformado, produzirão animais mosáicos. Nestas situações, os animais transgênicos só serão obtidos, após o cruzamento de indivíduos heterozigotos $\mathrm{F} 1$, originados do cruzamento dos animais mosaicos ou quiméricos, com animais normais (Notarianni \& Evans, 1992).

As várias técnicas de transferência de genes são aplicadas dependendo do tipo de expressão do transgene que se deseja (estável ou transiente) e do tipo de células a serem transformadas (células em cultura, explante de órgãos ou no próprio animal), diferentes. Para a produção de animais transgênicos é necessário que o transgene esteja presente e integrado nas células germinativas (óvulos ou espermatozóides). No entanto, quando somente a expressão transiente é desejada, diversas técnicas são utilizadas visando a transferência de genes em células cultivadas em meio de cultura (transformação in vitro) ou no próprio animal (transformação in situ).

a) Microinjeção de DNA em Pronúcleo

Esta técnica consiste na microinjeção de genes, diretamente, dentro do pronúcleo de um ovo recém fertilizado (Gordon et al., 1980). Geralmente, múltiplas 
moléculas de DNA, arranjadas em tandem, integram-se estavelmente no genoma do hospedeiro, em um único sítio de inserção (Jaenisch, 1988). Rearranjos, deleções, duplicações ou translocações no DNA hospedeiro, podem ocorrer no sítio de inserção (Mahon et al., 1988). Entretanto, nem sempre o DNA injetado integra-se ao genoma. Por exemplo, Lacey et al. (1986) observaram que o vírus do papiloma de bovinos ou integrava-se, estavelmente, ao genoma de camundongos transgênicos ou mantinha-se como um epissomo, dependendo da estrutura do DNA injetado.

A maior vantagem deste procedimento é a eficiência em gerar linhas transgênicas que expressem o transgene de maneira correta. Entretanto, esta técnica é limitada, não podendo ser utilizada em embriões, em estádio mais avançado do desenvolvimento (Gordon, 1980). Outras limitações observadas são: rearranjos causados no genoma da célula injetada e introdução de várias cópias do transgene, originando animais com expressão variável do transgene (Gordon \& Ruddle, 1981). Em animais domésticos, a proporção de indivíduos transgênicos, que se desenvolveram a partir de um ovo microinjetado, é menor do que aquela observada em camundongos. Isto ocorre devido a alguns fatores, tais como, dificil visualização do pronúcleo, disponibilidade de ovos recém fertilizados, sincronismo dos animais receptores e doadores, idade do animal doador e número de ovos transferidos, entre outros (Martin \& Pinkert, 1994).

Em aves, os pronúcleos feminino e masculino são mascarados pelo citoplasma opaco. É também dificil distinguir o pronúcleo masculino, que irá contribuir para a formação do zigoto, devido a presença de pronúcleos masculinos supranumerários. Não sendo possível injetar DNA, dentro do pronúcleo, injeta-se, então, no citoplasma próximo aos pronúcleos (Ginsburg \& Eyal-Giladi, 1987). A expressão de DNA exógeno, injetado no citoplasma de ovos fecundados, foi verificada por Naito et al. (1991a) e Sang \& Perry (1989). Os genes injetados mostraram-se, todavia, epissomais e perderam-se, gradativamente. A produção de galinhas transgênicas, por microinjeção de DNA, no disco germinal de zigotos e posterior cultura, ex vivo, do embrião até a eclosão, foi obtida, logo a seguir, por Love et al. (1994) e Naito et al. (1994a). Estes trabalhos 
demonstraram transmissão estável do DNA exógeno para a progênie, mas com baixa eficiência (menos de 1\% dos embriões injetados apresentaram o DNA exógeno).

b) Infecção por Retrovírus

Os retrovírus podem ser modificados, geneticamente, pela técnica de DNA recombinante e, então, utilizados como vetores de DNA. Ao contrário do DNA microinjetado, os retrovírus integram o gene exógeno, por um mecanismo precisamente definido, no genoma da célula hospedeira. Somente uma cópia do vírus é inserida, em determinado sítio do cromossomo e nenhum rearranjo no genoma é induzido, exceto para uma pequena duplicação de um seqüência do genoma, no sítio de integração (Jaenisch, 1988; Menck, 1998). A infecção por retrovírus pode ocorrer, por exposição das células a alta concentração do vírus, por co-cultura em monocamada de células infectadas com o retrovírus ou, no caso de aves, pela microinjeção do retrovírus, diretamente, no blastodisco (Pursel \& Rexroad, 1993).

A principal vantagem do uso de vetores retrovirais, para transferir genes em animais, é a facilidade de se introduzirem vírus em embriões, em vários estádios do desenvolvimento. No entanto, o tamanho do DNA a ser introduzido é limitado (menos de $6 \mathrm{~Kb})$ e, geralmente, pode apresentar problemas de expressão do gene, devido à alta instabilidade de tais vetores. Outras desvantagens desta técnica são: dificuldade em produzir o retrovírus portador do transgene; o animal resultante é um mosaico, sendo necessários, portanto, cruzamentos, para a obtenção de uma linhagem transgênica pura; a eficiência de transformação das células germinativas é baixa (Jaenisch, 1988; Pursel \& Rexroad, 1993).

Em aves, a transferência de genes, para linhagens germinativas, tem sido obtida, por infecção de retrovírus replicação-defectiva ou replicação-competente em embriões, logo após a postura dos ovos (Briskin et al., 1991; Bosselman et al., 1989a; Hughes et al., 1986; Salter \& Crittenden, 1989; Salter et al., 1987, 1993 e Shuman \& Shoffner, 1986), em óvulos não fecundados (Shuman \& Shoffner, 1986) ou em células germinativas primordiais (Vick et al., 1993a). Embora tais vetores retrovirais sejam 
apontados, como melhor técnica para a produção de galinhas transgênicas, ocorrem algumas desvantagens. Primeira: a proporção de embriões, oriundos de ovos infectados com vírus, que transmitem o DNA exógeno para as suas progênies, é relativamente baixa. Segunda: centenas ou milhares de ovos devem ser inoculados e um número similar de progênies deve ser examinado, quanto à presença do transgene, para identificar uma galinha transgênica. Terceira: vírus replicação-competente provocam viremia crônica, enquanto que vírus replicação-deficiente são dificeis de se propagarem eficientemente. Quarta: o tamanho do gene a ser introduzido, no vetor retroviral, é limitado para cerca de $2 \mathrm{~kb}$ para vírus replicação-competente e cerca de $6 \mathrm{~kb}$ para vírus replicação-deficiente. Vetores retrovirais, no entanto, permanecem muito atrativos, pois integram somente uma cópia do DNA exógeno no genoma da célula infectada (Etches, 1996).

Alguns dos problemas associados com a infecção por retrovírus já foram eliminados com a utilização da técnica denominada virofecção. Esta, consiste na cotransfecção de dois plasmídeos, um dos quais possui somente o DNA exógeno e o outro, os genes que codificam para as proteínas necessárias para a replicação e integração do vetor. Neste sistema, não são produzidas moléculas de RNA do vírus e, portanto, não há a formação de novas partículas virais (Flamant et al., 1994). Este procedimento mostrou um grande potencial para a introdução de modificações genéticas em células da blastoderme, sem a produção de vírus infecciosos (Flamant et al., 1994).

\section{c) Células Embrionárias Indiferenciadas ("stem cells")}

Concomitantemente com o desenvolvimento das técnicas de microinjeção e infecção por retrovírus, foram realizados estudos para estabelecer linhagens celulares, que pudessem participar da formação de animais quiméricos, colonizando as células germinativas. As células embrionárias indiferenciadas são estabelecidas in vitro, a partir do cultivo de células oriundas de embriões, em estádio de blastocisto. Estas células mantêm sua característica de pluripotência e conservam seu cariótipo normal, quando em cultura (Wagner et al., 1985). Genes podem ser eficientemente introduzidos, nestas células, por transferência direta de DNA ou por meio de retrovírus (Jaenisch, 1988). 
Quando injetadas em um blastocisto hospedeiro, estas células transformadas podem colonizar o embrião e contribuir para a formação da linhagem germinativa, originando um animal quimérico para o gene exógeno (Robertson et al., 1986). A possibilidade de seleção prévia, in vitro, de um genótipo particular, antes da introdução das células no embrião, constitui o maior benefício proporcionado por este procedimento. Ademais, esta técnica permite a inserção sítio-específica do transgene, por meio da recombinação homóloga (Capecchi, 1989). No entanto, a grande desvantagem para a produção de animais transgênicos, é que não se pode prever o destino das células e estas podem vir a não dar origem às células germinativas. Outro fator importante, é que os animais produzido são quiméricos e, como no caso da infecção por retrovírus, são necessários cruzamentos para a obtenção de uma linhagem transgênica pura (Gordon, 1989; Pursel \& Rexroad, 1993).

Nas espécies domésticas, a utilização desta técnica é limitada até os dias de hoje, pelo fato dos animais obtidos serem quiméricos. Isto implica em um aumento no tempo necessário para a obtenção do animal fundador homozigoto (pelo menos uma geração a mais), sendo, principalmente para bovinos, um importante obstáculo a ser considerado (Menck, 1998).

\section{d) Espermatozóides como Vetores}

Espermatozóides podem ser utilizados, como vetores, para a introdução de genes exógenos no núcleo de ovócitos, no momento da fecundação. Camundongos e suínos transgênicos foram produzidos, a partir da incubação dos espermatozóides, em um meio contendo o DNA exógeno, e com a subsequente utilização destes espermatozóides para a fecundação in vitro (Lavitrano et al., 1989) ou inseminação no oviduto (Lauria \& Gandolfi, 1993). Trabalhos adicionais demonstraram a presença de genes exógenos em espermatozóides de camundongos (Hochi et al., 1990), bovinos (Castro et al., 1991), insetos (Atkinson et al., 1991) e galinhas (Nakanishi \& Iritani, 1993; Rottmann et al., 1992 e Squires \& Drake, 1993). No entanto, esta técnica é de dificil reprodução e pouco 
eficiente para a produção de animais transgênicos (Pursel \& Rexroad, 1993 e Squires \& Drake, 1993).

e) Eletroporação

Transfeç̧ão de DNA mediada por campo elétrico, comumente denominada de eletroporação, tem sido utilizada tanto para a transferência transiente de genes, quanto para transformação estável (Keown et al., 1990). Quando células são submetidas a um campo elétrico de voltagem, regiões da membrana citoplasmática sofrem quebras reversíveis, resultando na formação de poros suficientemente grandes para a passagem de macromoléculas. O DNA, que entra na célula, permanece livre no citosol e no nucleoplasma (Bertling et al., 1987). Devido a este fato, são observadas baixas taxas de mutação no genoma das células transformadas (Drinkwater \& Klinedinst, 1986).

As vantagens desta técnica são: facilidade de operação, reprodutibilidade das condições, aplicabilidade às células que crescem em camadas ou em suspensão e capacidade de controlar o número de cópias de moléculas de DNA, a ser transfectada. Alterando-se os parâmetros para experimentos específicos, é possível introduzir uma ou mais cópias de DNA por eletroporação (Keown et al., 1990).

Muitos tipos de células, resistentes à transfecção por outras técnicas, são facilmente transformadas por eletroporação. Estas células incluem os linfócitos (Potter et al., 1984), células indiferenciadas do sistema hematopoético (Toneguzzo \& Keating, 1986) e células de hepatoma de ratos (Sureau et al., 1986). Recentemente, trabalhos demonstraram a aplicação da eletroporação para a transferência de genes em embriões de galinha (Muramatsu et al., 1997a e 1998).

\section{f) Co-precipitação com Fosfato de Cálcio}

Esta técnica foi desenvolvida, originalmente, para aumentar a infectividade do DNA de adenovírus (Graham \& Van Der Eb, 1973). Consiste na mistura de DNA purificado com tampões, contendo fosfato e cloreto de cálcio, resultando na formação de 
um precipitado, que é exposto à cultura de células a serem transformadas (Keown et al., 1990). O DNA é incorporado pela célula por vesículas fagocíticas, provocando rearranjos em suas sequências durante o transporte até o núcleo. Transformação estável foi observada, em uma variedade de tipos celulares, com uma eficiência de transformação de $10^{-3}$ a $10^{-4}$ (Chen \& Okayama, 1987 e Keown et al., 1990).

\section{g) Lipossomos}

Esta técnica consiste na utilização de lipossomos, como carreadores de DNA, para a transfecção de células em cultura. Os lipossomos são vesículas fosfolipídicas unilamelares que podem ser carregadas com moléculas de DNA (SchaeferRidder et al., 1982 e Wong et al., 1980). Estas vesículas fundem-se, com a membrana plasmática das células a serem transfectadas e o DNA atravessa o citoplasma e entra no núcleo (Itani et al., 1987). Este procedimento tem-se mostrado eficiente não só para expressão estável, como para transiente, e tem sido utilizado tanto para células em suspensão, quanto em camadas. Uma aplicação promissora desta técnica é a capacidade de transfecção in vivo (Nicolau et al., 1983). Sua maior limitação, no entanto, é a complexidade no preparo dos lipossomos e a não especificidade dos lipossomos a um determinado tipo celular (Monastersky, 1994).

\section{h) Lipofecção}

Esta técnica consiste na utilização de um lipídeo sintético catiônico para transportar DNA, através da membrana plasmática de células de mamíferos, após fagocitose ou fusão (Papahadjopoulos et al., 1975). Um dos componentes mais utilizados para a formação do lipídeo catiônico é a lipofectina. Esta molécula associa-se, espontaneamente, ao DNA e, durante o processo de sonicação, vesículas unilamelares são formadas, englobando o DNA. A lipofectina confere carga positiva às vesículas formadas. Quando estas são colocadas em contato com as células a serem transformadas, ocorre uma fusão com a membrana plasmática das células e o DNA é transferido para dentro do citoplasma. Lipofectina é relativamente não-tóxica, comparada a outros 
produtos de transfecção, tais como: fosfato de sódio e dextran-DEAE. Felgner et al. (1987) descreveram altos níveis de expressão transiente do DNA introduzido, em três diferentes linhagens de células, utilizando a técnica de lipofecção, que apresentou uma eficiência de transfecção de 6 a 80 vezes maior que a co-precipitação com fosfato de cálcio. As vantagens deste procedimento em relação aos lipossomos são: maior eficiência de transformação e melhor incorporação de DNA dentro das vesículas lipídicas catiônicas.

Em aves, esta técnica foi utilizada para a transfecção de embriões de galinha in situ (Demeneix et al., 1994; Muramatsu et al., 1997a e Rosenblum \& Chen, 1995) e em cultura de células da blastoderme e de células primárias de fibroblastos de galinhas (Brazolot et al., 1991).

\section{i) Transfecção de DNA Mediada por Dextran DEAE}

Consiste na preparação de uma solução de dextran DEAE, a adição do DNA de interesse a esta solução e a transferência desta mistura para as células em cultura a serem transformadas (Lopata et al., 1984). Devido à facilidade em preparar as amostras e a possibilidade de transfectar um grande número de células, esta técnica tem sido mais utilizado para analisar a expressão de genes que codificam para proteínas secretadas ou de superfície celular (Kriegler, 1990). Os eventos químicos que levam à absorção celular do DNA não são claramente compreendidos (Kriegler, 1990).

Este procedimento tem sido utilizado somente para a transfecção transiente de células em cultura, apresentando eficiência de transformação de cerca de 80\% (Lopata et al., 1984). Apesar desta alta eficiência de transformação, o DNA introduzido nas células está sujeito a altas taxas de mutação (Calos et al., 1983 e Razzaque et al., 1983).

\section{j) Transfecção de DNA Mediada por Polibrene}

Esta técnica foi descrita, inicialmente, para transfectar fibroblastos de embriões de galinhas com o DNA do vírus do Rous Sarcoma (Kawai \& Nishizawa, 
1984), sendo utilizada, posteriormente, para a transformação estável de células CHO (células do ovário de hamster). Embora também produza transformantes estáveis em outras linhagens celulares, não foi demonstrado aumento na freqüência de transfecção destas células, quando comparado com a técnica de co-precipitação com fosfato de cálcio. Em células $\mathrm{CHO}$, a freqüência de transformantes estáveis mediada por polibrene é cerca de 15 vezes maior que a obtida por co-precipitação com fosfato de cálcio (Chaney et al., 1986).

\section{k) Método utilizando Laser}

Neste método, o DNA, a ser transfectado nas células, é dissolvido no meio de cultura, onde as células serão cultivadas. A absorção do DNA pelas células é mediada pela introdução, na membrana plasmática, de minúsculas quebras obtidas, por breves

pulsos de um laser. As células promovem, rapidamente, o reparo das membranas, mas o tempo é suficiente para a entrada do DNA exógeno. A eficiência de transfecção estável depende da concentração de DNA, no meio de cultura e foi observada ser da ordem de $0,6 \%$ (Kurata et al., 1986).

\section{1) Injeção Direta Intramuscular de DNA}

Esta técnica baseia-se na injeção de vetores de DNA puros em células musculares esqueléticas de animais vivos. Foi primeiramente reportada por Wolff et al. (1990), onde plasmídeos não replicativos expressavam as proteínas sintetizadas em células musculares de camundongos. Neste experimento, foi observado que o DNA injetado não estava integrado no genoma das células musculares, que possuía forma circular e não se replicava. A partir deste trabalho, diversos outros surgiram utilizando esta técnica, como sistema de liberação de genes codificadores de antígenos (Hoffman et al., 1997; Schirmbeck et al., 1995; Ulmer et al., 1993 e Wang et al., 1995). 
m) Transferência de Células da Blastoderme Transfectadas

A blastoderme de embriões, no estádio $X$ do desenvolvimento (Eyal-Giladi \& Kochav, 1976), está no início da formação do hipoblasto e, portanto, é pluripotente e pode ser transferida de um embrião para outro (Marzullo, 1970). Aves, com células somáticas e germinativas quiméricas foram produzidas por injeção de células da blastoderme, diretamente, na cavidade subgerminal de embriões receptores (Naito et al., 1991b; Petitte et al., 1990 e Watanabe et al., 1992). Uma galinha quimérica foi produzida, com células das linhagens White Leghorn e Barred Plymouth Rock, mas a freqüência de indivíduos da progênie, portadores das células da blastoderme transferida, foi de somente 0,3\% (Petitte et al., 1990). Células da blastoderme podem também ser eficientemente transfectadas, por meio da lipofecção, sendo injetadas, posteriormente, nos embriões receptores (Brazolot et al., 1991 e Fraser et al., 1993). A transferência de genes, em células embrionárias indiferenciadas derivadas da blastoderme (células ES), após serem cultivadas in vitro por 48 horas, foi demonstrada por Etches et al. (1993). A utilização da técnica de transferência de células da blastoderme transfectadas, para a produção de aves transgênicas, no entanto, depende da eficiência, com que as células da blastoderme transferidas irão colonizar as células germinativas do embrião receptor.

n) Transferência de Células Germinativas Primordiais Transfectadas

As células germinativas primordiais ("primordial germ cells" - PGCs) são progenitoras dos óvulos e espermatozóides. Em galinhas, originam-se no epiblasto e movem-se para a região crescente germinal, onde se multiplicam. Em seguida, entram no sistema vascular embrionário em desenvolvimento e circulam temporariamente pelo embrião. Finalmente, migram para as futuras gônadas, onde proliferam e diferenciam-se em espermatogônias e ovogônias (Kuwana, 1993). A manipulação das células germinativas primordiais contribui, diretamente, para a introdução de DNA exógeno na linhagem germinativa.

Vários trabalhos têm demonstrado a produção de galinhas, com células germinativas quiméricas, obtidas pela transferência de PGCs, oriundas da região 
crescente germinal (Vick et al., 1993a,b e Wentworth et al., 1989) ou do sistema vascular embrionário (Petitte et al., 1991 e Simkiss et al., 1989). As PGCs transferidas diferenciam-se normalmente em células germinativas e proles viáveis são obtidas (Vick et al., 1993a,b e Wentworth et al., 1989). Entretanto, a produção de proles derivadas das PGCs é baixa, devido principalmente a dificuldade de obtenção das PGCs, que serão transferidas aos embriões receptores (Vick et al., 1993a). Para aumentar a eficiência de PGCs transferidas, foi desenvolvida uma nova técnica, baseada na centrifugação por gradiente de densidade de Ficol, visando à obtenção de altas concentrações de células germinativas primordiais, oriundas de sangue embrionário (Naito et al., 1994b; Tajima et al., 1993 e Yasuda et al., 1992).

As células germinativas primordiais podem ser transfectadas in vivo, por meio da injeção de uma mistura de DNA e lipossomos diretamente no sistema circulatório de embriões receptores (Watanabe et al., 1994) ou serem transfectadas in vitro por lipofecção e, então, transferidas para embriões receptores (Naito et al., 1994b).

\section{o) Biolística}

Neste sistema, micropartículas de ouro ou tungstênio, contendo o DNA exógeno adsorvido, são aceleradas em alta velocidade, penetrando as células-alvo e liberando o DNA, de forma não letal (Klein et al., 1987). Diversas espécies de animais foram transfectados, pela biolística, tais como: protozoários, insetos, peixes, anfibios, camundongos, ratos, coelhos, macacos, galinhas, bovinos, entre outros. Atualmente, a biolística tem recebido grande atenção, devido à facilidade, praticabilidade e rapidez nas operações, além da relativa independência, quanto ao uso de genótipos e de protocolos específicos de cultura de tecidos. Esta técnica será detalhada adiante. 


\title{
2.2 PRINCÍPIOS BÁSICOS DA BIOLÍSTICA
}

\begin{abstract}
A biolística é um método fisico para a introdução de ácidos nucléicos e outras substâncias no interior de células e tecidos intactos, pela aceleração de micropartículas de metal a alta velocidade. Este processo tem sido descrito de diferentes formas e denominado de várias maneiras: bombardeamento de partículas, bombardeamento de micropartículas, aceleração de partículas, biobalística, "gene gun", entre outros. Os inventores deste processo, para uniformizar os diferentes termos e aparatos associados ao disparo de materiais biológicos no interior de células-alvos, denominaram-no biolística (Sanford et al., 1993).

O processo biolístico, inventado em 1984, por E. D. Wolf, N. K. Allen e J.
\end{abstract} C. Sanford, foi originalmente desenvolvido para introduzir genes exógenos, no genoma nuclear de plantas superiores (Klein et al., 1987). Comparada com outras técnicas de transformação, a biolística pode ser considerada como o sistema que demonstra a menor especificidade quanto uso de genótipos, permitindo trabalhar com espécies antes julgadas de dificil transformação. Apresenta ainda outras vantagens como: bombardeamento simultâneo de muitas células, liberação de altas doses de DNA, co-transformação com dois ou mais plasmídeos, independência quanto ao uso de protocolos específicos de cultura de tecidos e relativa praticabilidade e eficiência da técnica (Klein et al., 1992; Sanford et al., 1993).

Além da transferência de genes em plantas, a biolística tem sido utilizada eficientemente na transformação de diversos microrganismos, tais como: leveduras, fungos filamentosos (Armaleo et al., 1990 e Fungaro et al., 1995), algas (Schiedlmeier et al., 1994), bactérias (Smith et al., 1992) e protozoários (Vainstein et al., 1994). Também foi o primeiro método a tornar possível a transformação de genomas de organelas, como cloroplastos (Boynton et al., 1988; Svab et al., 1990 e Ye et al., 1990) e mitocôndrias (Fox et al., 1988 e Johnston et al., 1988).

Os primeiros trabalhos, demonstrando a aplicação da biolística para a transformação de células animais, surgiram no final da década de 80 e início da década de 
90 (Williams et al., 1991; Yang et al., 1990 e Zelenin et al., 1989). Desde então, muitos avanços foram conseguidos, como por exemplo, a transformação de células em cultura, de órgãos isolados e de tecidos de animais vivos. $\mathrm{O}$ desenvolvimento desta técnica tem-se mostrado importante para os campos da terapia e imunização gênica, assim como para o estudo básico da função e regulação de genes e promotores tecidos-específicos.

Para assegurar a eficiência de liberação de DNA, dentro da célula e diminuir os efeitos prejudiciais intrínsecos da biolística, faz-se necessário otimizar os fatores, que afetam a eficiência de transferência de genes, obtendo-se dessa forma resultados repetitivos e consistentes (Birch \& Franks, 1991). Independente da espécie a ser transformada, os principais fatores, que devem ser considerados, são: 1) escolha do acelerador de micropartículas, 2) escolha das micropartículas, 3) parâmetros fisicos, 4) parâmetros biológicos (Sanford et al., 1993).

\subsubsection{ACELERADOR DE MICROPARTÍCULAS}

Há muitas formas de aceleração de partículas microscópicas a velocidade altas, como é exigido pelo processo biolístico. Dos vários métodos de aceleração, o que tem-se mostrado mais eficiente é o de aceleração de micropartículas na superficie de um

carreador macroscópico ou macrocarreador. O macrocarreador, em todos os métodos, é impulsionado por uma onda de choque. Esta onda pode resultar de: explosão química, explosão elétrica de uma gota d'água, descarga de ar comprimido e choque de gás hélio ou de nitrogênio, gerado pelo mecanismo de ruptura de membrana. $\mathrm{O}$ macrocarreador pode ser qualquer objeto pequeno, cuja superficie frontal possa carregar micropartículas e, cuja superficie oposta apresente integridade coesiva bastante, para absorver a energia da onda de choque e suportar aceleração súbita seguida de desaceleração abrupta (Sanford et al., 1993).

$\mathrm{O}$ primeiro equipamento desenvolvido utilizava pólvora para acelerar as micropartículas de metal. Estas micropartículas, cobertas de DNA, são colocadas em um macrocarreador de náilon, que é acelerado, dentro de um tubo, pela explosão da pólvora, 
até atingir um anteparo de impacto. Somente as micropartículas continuam sua trajetória, por uma pequena abertura no anteparo, até atingirem o tecido-alvo (Klein et al., 1987). Todo esse processo ocorre, dentro de uma câmara, sob vácuo parcial. Este modelo básico não permite o controle da velocidade das partículas $\mathrm{e}$, devido às variações na quantidade de pólvora, que acelera o macrocarreador, apresenta alto grau de variabilidade em cada bombardeamento. Este sistema causa também dano apreciável ao tecido-alvo, devido principalmente à onda de choque e ao choque acústico. $\mathrm{O}$ uso de peneiras, entre o anteparo de impacto e o tecido, minimiza o dano às células e melhora $o$ perfil de distribuição das partículas (Russel et al., 1992).

Novos sistemas de aceleração foram desenvolvidos, com o objetivo de obter-se maior controle na velocidade, dispersão e penetração das micropartículas e de atenuar os danos causados aos tecidos-alvos. Sanford et al. (1991) desenvolveram um sistema de bombardeamento, onde uma pressão controlada de gás hélio acelera uma membrana de plástico carregada de partículas (membrana carreadora). Após percorrer curta distância, a membrana carreadora é desacelerada, pelo impacto em uma tela fixa (tela de retenção) e somente as partículas continuam o seu percurso, até atingirem o explante-alvo, sob vácuo parcial. A pressão é controlada por um disco de ruptura, que pode apresentar diferentes espessuras, de acordo com a pressão desejada. A distância, entre o disco de ruptura e a membrana carreadora, pode ser modificada, permitindo variar a velocidade das partículas, conforme o tipo de tecido-alvo a ser utilizado.

Morikawa et al. (1989) utilizaram um sistema semelhante ao do gás hélio, mas, tendo o nitrogênio, como fonte de força propulsora. $\mathrm{O}$ mesmo grupo (lida et al., 1990) também desenvolveu um equipamento pneumático de aceleração de partículas. O protótipo é bastante similar àquele, que emprega pólvora, mas o agente propelente é o ar comprimido, que permite controlar a velocidade das partículas.

McCabe et al. (1988) desenvolveram um equipamento, que impulsiona as micropartículas, por meio de onda de choque gerada por descarga elétrica. A aceleração das partículas é obtida por um capacitor de alta voltagem, que vaporiza uma pequena gota d'água e cria uma explosão, que impulsiona uma membrana carregada de partículas 
recobertas de DNA. Rech et al. (1991) desenvolveram um aparelho de descarga elétrica modificado, utilizando baixa voltagem e alta capacitância. Descreveram também a otimização de algumas variáveis associadas a este aparelho (Aragão et el., 1993). Takagi \& Kimura (1997) demonstraram outro tipo de modificação para o aparelho de descarga elétrica, utilizando eletrodos (fio de metal) de descarga, em substituição à gota d'água.

Um equipamento mais prático, de baixo custo e de fácil construção, foi desenvolvido por Finer et al. (1992), empregando um suporte de filtro, adaptado a um tubo ligado a fonte de gás pressurizado. As partículas de metal com o DNA adsorvido são colocadas sobre o filtro, que recebe um pulso de gás hélio, controlado por uma válvula solenóide.

Sautter et al. (1991) desenvolveram um sistema de bombardeamento de partículas, denominado "micro-targeting". Neste sistema, uma mistura de DNA e partículas de metal é vaporizada e acelerada, por um pulso de gás, em tubo capilar. $\mathrm{O}$ tubo capilar é direcionado para o tecido-alvo, com a ajuda da microscopia. Como o nome indica, este sistema foi desenvolvido para permitir o bombardeamento de tecidos, com diâmetro inferior a $0,15 \mathrm{~mm}$, podendo ser regulado para a penetração das partículas, em camadas celulares específicas.

Apesar dos avanços ocorridos nos aparelhos existentes, há necessidade de otimizarem-se os parâmetros associados a cada sistema de aceleração, quando este for utilizado em uma espécie ainda não transformada por qualquer um dos sistemas. A escolha do sistema de aceleração de micropartículas deve levar em consideração os seguintes atributos: segurança, repetibilidade, flexibilidade para ser utilizado em mais de uma aplicação e em mais de uma espécie, controle mais acurado sobre a velocidade e a dispersão das partículas, opção para ser utilizado como portátil, mínimo dano ao tecidoalvo e uso de diferentes micropartículas (Sanford et al., 1991).

Nenhum dos sistemas, até agora discutidos, satisfaz a todos os requisitos acima indicados. O sistema de aceleração, utilizando pressão de gás hélio, é o que preenche maior número de atributos desejados (Sanford et al., 1991). 


\subsubsection{MiCROPARTÍCULAS}

O tipo e o tamanho das micropartículas dependem do tecido a ser transformado. A princípio, qualquer partícula pode ser utilizada, como carreadora de DNA, desde que seja quimicamente pouco reativa, apresente alta densidade, seja biologicamente inerte e esteja disponível, em diferentes formatos e tamanhos adequados (Birch \& Franks, 1991 e Lacorte et al., 1996). As micropartículas mais utilizadas, como carreadoras de DNA, são o tungstênio e o ouro.

A escolha de partículas de tungstênio, como micropartícula, apresenta algumas vantagens, tais como: custo reduzido, disponibilidade em diversos tamanhos $(0,2$ a $10 \mu \mathrm{m})$ e facilidade em ligar-se ao DNA. As desvantagens destas partículas, no entanto, são: potencialmente tóxicas para certos tipos de células (Armaleo et al., 1990; Russel et al. 1992), suscetíveis à oxidação que pode alterar a ligação com o DNA, degradam catalítica e progressivamente sua associação com o DNA e são altamente heterogêneas, em tamanho e forma, impedindo a otimização do tamanho da partícula para um tipo celular particular.

As partículas de ouro estão disponíveis, em uma limitada variação de tamanho (de 1 a $3 \mu \mathrm{m}$ ), são uniformes em tamanho e formato e permitem a otimização do tamanho da partícula para determinado tipo de célula. Outras características positivas do ouro são: é biologicamente inerte, não é tóxico para as células, é aprovado pela FDA (Food and Drug Administration) como agente terapêutico em humanos e não degrada cataliticamente sua associação com o DNA. As maiores desvantagens do ouro são: é relativamente caro, não é estável em suspensões aquosas estéreis e as partículas aglomeram-se irreversivelmente com o tempo (Sanford et al., 1993).

Outras partículas de metal, como platina e irídio, foram utilizadas por Sanford et al. (1993), como carreadoras de DNA. Entretanto, ambas partículas mostraram baixa taxa de transformação, devido tanto ao diâmetro irregular das partículas, como sua baixa ligação ao DNA. Partículas de baixa densidade, como pedaços de vidro ( $1 \mathrm{~mm}$ de diâmetro e 3-30 $\mathrm{mm}$ de comprimento) e sílica também foram testadas por Sanford et al. (1993). Sua baixa densidade, no entanto, reduz drasticamente a 
aceleração e compromete a eficiência de penetração das partículas. Células desidratadas de Escherichia coli, Agrobacterium tumefaciens e leveduras, utilizadas como forma natural de encapsulação de DNA, também foram testadas (Sanford et al., 1993), apresentando a vantagem de eliminação dos problemas com heterogeneidade no tamanho das partículas, com protocolos de precipitação do DNA e com aglomeração das partículas. Experimentos realizados por Rasmussen et al. (1994) indicaram que células desidratadas de E. coli, portando um vetor de expressão, podem ser usadas para bombardear suspensão de células de tabaco ou milho, resultando em expressão da $\beta$ glucuronidase (GUS).

\subsubsection{Tamanho das Partículas}

O tamanho das partículas varia, em função do tamanho das células a serem transformadas. Como regra geral, as partículas devem possuir tamanho, em torno de 1/10 do diâmetro da célula-alvo (Sanford et al., 1993). No entanto, há experimentos que negam esta afirmativa, por exemplo: células da epiderme de camundongos, com diâmetro inferior a $20 \mu \mathrm{m}$, foram transformadas, com partículas de 3,9 $\mu \mathrm{m}$ (Sanford et al., 1993). Habitualmente, bactérias e fungos têm sido transformados, com partículas de 0,1 a 1,0 $\mu \mathrm{m}$; células vegetais, com partículas de 0,2 a $1,5 \mu \mathrm{m}$; e células animais, com partículas de 1,0 a 5,0 $\mu \mathrm{m}$ de diâmetro (Lacorte et al., 1996).

\subsubsection{Precipitação do DNA sobre as Micropartículas}

A precipitação do DNA sobre as micropartículas é uma das mais importantes fontes de variação da eficiência de transformação por biolística. A precipitação do DNA ocorre muito rapidamente, sendo impossivel obter uma mistura de reação uniforme, pois ouro e tungstênio também precipitam facilmente. Sanford et al. (1993) demostraram que o padrão de precipitação e agregação do DNA é único e não se reproduz. Eles observaram também que a taxa de transformação decai sensivelmente no verão, possivelmente devido à umidade do ar, responsável pela aglomeração das partículas. 
Os procedimentos empregados para a precipitação do DNA, sobre as micropartículas, podem muitas vezes influenciar na interação DNA-partícula e na quantidade e forma como o DNA entra na célula. A formação de agregados de micropartículas danifica as células-alvos, resultando em baixa eficiência de transformação. Estes agregados são, principalmente, conseqüências do procedimento de precipitação utilizado (Klein \& Fitzpatrick-McElligott, 1993).

Vários protocolos de precipitação de DNA às micropartículas têm sido publicados (Sanford et al., 1993). O mais recomendado, desenvolvido por Klein et al. (1988), utiliza $\mathrm{CaCl}_{2}$ e espermidina. $\mathrm{O}$ DNA adsorvido às micropartículas é ressuspendido em etanol $100 \%$ e colocado sobre a membrana carreadora. $\mathrm{O}$ etanol evapora e as micropartículas com DNA permanecem secas, sobre a superficie da membrana. A quantidade de DNA e de partículas são fatores importantes. DNA, em excesso ou com impurezas, pode causar aglomeração das partículas (Aragão et al., 1993 e Klein et al., 1988).

A quantidade de DNA influencia também o nível de expressão do gene introduzido. Alguns estudos mostram que pequenas quantidades de DNA são necessárias para máxima expressão do gene exógeno (Eisenbraun et al., 1993), outros descrevem uma associação positiva entre expressão transiente e aumento da concentração de DNA (Baldarelli \& Lengyel, 1990).

\subsubsection{PARÂMETRos Físicos}

Os parâmetros fisicos, a seguir discutidos, referem-se ao sistema de aceleração, que utiliza o gás hélio como fonte de força, por ser o mais amplamente utilizado e otimizado para diversas espécies.

\subsubsection{Velocidade de Impacto}

A velocidade de impacto refere-se à velocidade das micropartículas, ao atingirem as células-alvo. Há muitos parâmetros, que interagem e afetam a velocidade de 
impacto. Estes incluem pressão de choque do gás hélio, distância entre a membrana de ruptura e a membrana carreadora, distância da membrana carreadora até a tela de retenção e distância das células-alvo até a membrana carreadora (também denominada distância percorrida pelo DNA-micropartículas). Em condições de altas pressões, a velocidade de impacto das micropartículas será mais alta, se a distância entre a fonte de força e a membrana carreadora for pequena ou, se a distância entre a membrana carreadora e a tela de retenção for longa. Grandes distâncias percorridas pelo DNAmicropartículas reduzem a velocidade de impacto, mas, por outro lado, otimizam a dispersão das partículas e minimizam os efeitos da onda de choque nas células. Adicionalmente, o uso de partículas menores e de vácuo reduzido também atenuam a velocidade de impacto (Sanford et al., 1993).

A utilização do gás hélio, como fonte de força, é funcional de 600 a 2400 psi. De acordo com Sanford et al. (1993), 600 psi é o suficiente para alguns casos de transformação, mas insuficiente para a maioria das aplicações. O valor de 1000 psi mostrou-se ideal para muitos organismos estudados. É oportuno salientar que a pressão do gás hélio influi diretamente na variação da velocidade, mas não necessariamente resulta em aumento da taxa de transformação. Sob condições de alta pressão, verificamse limites máximos distintos, entre as vantagens e os efeitos negativos, na eficiência de transformação.

Foram testadas distâncias, variando de 1 a $20 \mathrm{~mm}$, entre a fonte de força e a membrana carreadora. Verificou-se que distâncias menores incrementam a velocidade de impacto, ocasionando, porém, variação no percurso da membrana até a tela de retenção. Geralmente, o melhor coeficiente de transferência de energia efetiva, com mínima variabilidade, ocorre com distâncias de 6 a 12 mm (Sanford et al., 1993).

Uma distância de $10 \mathrm{~mm}$ entre a membrana carreadora e a tela de retenção proporciona uma velocidade ótima, sem acentuadas variações na orientação do trajeto ou na freqüência de transformação. $O$ aumento da distância altera, proporcionalmente, a velocidade e, por conseqüência, provoca variações na orientação do trajeto da membrana carreadora (Sanford et al., 1993). 
A distância percorrida pelo DNA-micropartículas até as células-alvo não é muito crítica quando são utilizadas micropartículas grandes. Com micropartículas pequenas, porém, a situação é inversa, a exemplo do que ocorre com a transformação de bactérias, onde a distância deve ser minimizada para manter-se velocidade adequada (Sanford et al., 1993).

Estes parâmetros citados interagem todos, entre si. Por exemplo, o aumento da pressão do gás hélio pode ser compensado: pelo incremento da distância entre a fonte de força e a membrana carreadora, pelo decremento da distância entre a membrana carreadora e a tela de retenção ou pelo incremento da distância percorrida pelo DNA-micropartículas até o alvo (Klein et al., 1992; Sanford et al., 1993).

\subsubsection{Vácuo/Gás Residual}

O gás residual, que recobre as amostras, dentro do aparelho de biolística, deve ser retirado. Este gás pode afetar a eficiência de transformação, por duas razões. Primeira: as micropartículas perdem, drasticamente, aceleração ao passarem por qualquer gás. Esta perda será tão mais acentuada, quanto menor for a partícula. Por conseqüência, a remoção do gás minimiza a perda de aceleração e viabiliza o uso de micropartículas extremamente pequenas, exigidas na transformação bacteriana. Segunda razão: o gás residual pode transmitir, potencialmente, uma perigosa onda de choque. $O$ gás hélio, por seu baixo peso molecular, atenua a intensidade desta onda de choque (Sanford et al., 1993).

Comumente, o gás residual é retirado, por uma bomba de vácuo, até que atinja valores, entre 710 a 740 mmHg (28-29"Hg). Pressões de vácuo maiores não são geralmente práticas, em decorrência da pressão do vapor d'água formada pela própria amostra biológica. A intensidade do vácuo deve ser reduzida para certas aplicações, como por exemplo: o bombardeamento de pele de rato in situ requer pequena quantidade de vácuo de aproximadamente $510 \mathrm{mmHg}$, caso contrário, a sucção no tecido pode causar danos às células e reduzir o nível de expressão do gene inserido (Williams et al., 
1991). Pela mesma razão, tecido de figado de rato não tolera nenhum vácuo (Williams et al., 1991).

A eficiência de transformação de certos tecidos pode ser aumentada, preenchendo a câmara de bombardeamento com gás hélio antes da aplicação do vácuo, de forma que o residual seja de gás hélio e não de ar. Esta vantagem é mais bem observada em microrganismos, onde a taxa de transformação pode ser aumentada, de cinco a seis vezes, em bactérias (Smith et al., 1992) e quatro vezes, em leveduras (Sanford et al., 1993). No entanto, este procedimento não se aplica indiscriminadamente a todos organismos. Em suspensão de células de tabaco, por exemplo, o beneficio é muito pequeno ou ausente.

\subsubsection{Onda de Choque/Choque Acústico}

O choque acústico e a onda de choque, gerados durante a aceleração da membrana carreadora, podem causar sérios danos as células e até destruí-las (Russel et al., 1992). Mesmo não sendo letal, estes prejudicam a subsequente divisão, crescimento e regeneração celular. Substituir o gás residual é importante para manter a velocidade das partículas, mas seu efeito, na redução da intensidade da onda de choque, é pequeno (Sanford et al., 1993).

Os maiores efeitos da onda de choque e do choque acústico, na eficiência de transformação, são verificados nos aparelhos que utilizam pólvora, diferentemente do que ocorre nos aparelhos com gás hélio, onde os efeitos não são limitantes (Sanford et al., 1993). Os danos nas células, provocados pela onda de choque, podem ser reduzidos com a aplicação de filtros, peneiras e outras formas de cobertura para o tecido-alvo. Em aparelhos, que utilizam pólvora, esta técnica produziu resultados. Em sistemas com gás hélio, não se verificou o mesmo efeito, em termos de incremento no número de células transformadas (Russel et al., 1992). 


\subsubsection{PARÂMETROS BIOLógICOS}

Alguns parâmetros biológicos são importantes para o sucesso da transformação por biolística. Primeiro: com genes marcadores compatíveis com o tipo de célula e organismo a ser transformado, deve-se construir um vetor com promotor forte e de expressão efetiva no tecido-alvo desejado. Segundo: as células-alvos devem estar prontas e receptivas para a transformação. Terceiro: deve ocorrer altas taxas de penetração das partículas, de sobrevivência e de crescimento celular após o bombardeamento.

\subsubsection{Vetores}

Os vetores utilizados, nos experimentos de biolística, devem ser adequados para otimizar os protocolos de transformação e para introduzir seqüências de interesse, de forma estável. A expressão de genes heterólogos, em um organismo, requer elementos estruturais, que sejam reconhecidos pelo sistema de transcrição do organismo transformado, tais como: promotores apropriados que possam ser replicativos ou integrativos, amplificadores ("enhancers"), sinais de terminação e poliadenilação, além de genes marcadores e/ou de seleção apropriados. A biolística permite o estudo da expressão gênica em tecidos intactos, sendo, portanto, uma técnica adequada para o estudo de promotores com regulação temporal ou tecidos-específicos. Alguns trabalhos demonstraram a importância da escolha de um promotor adequado para otimizar os protocolos de transformação e para introduzir seqüências de interesse, de forma estável (Burkholder et al., 1993; Cheng et al., 1993 e Tang et al., 1992). Para a transformação de células animais in vitro e in vivo, os genes marcadores mais utilizados são os genes da $\beta$ galactosidase $(\beta$-gal) e o gene da luciferase $(l u c)$, sob o controle do promotor constitutivo do citomegalovírus (CMV) ou do vírus de símios 40 (SV40) (Baldarelli \& Lengyel, 1990; Burkholder et al., 1993; Cheng et al., 1993; Jiao et al., 1993; Williams et al., 1991 e Yang et al., 1990).

O tamanho do vetor não parece ser um fator limitante para a biolística. Vetores de fago $\lambda(50 \mathrm{~Kb})$ possuem tamanho superior aos outros vetores mais 
comumente utilizados e, no entanto, apresentam altas taxas de transformação (Rasmussen et al., 1994). Da mesma forma, células intactas, por exemplo E. coli, podem ser liberadas como micropartículas, indicando que cromossomos ou genomas inteiros podem ser introduzidos, por meio da biolística (Sanford et al., 1993). DNA ou RNA, na forma circular ou linear, e como fita simples ou dupla podem ser introduzidos, pela biolística (Sanford et al., 1993).

\subsubsection{Fisiologia e Idade das Células}

Em geral, os alvos ideais para biolística são células saudáveis, que sejam receptivas para transformação e suportem o estresse causado pelo bombardeamento. Em outras palavras, as mais apropriadas são as células jovens, em intensa divisão celular. Há, entretanto, exceções e a idade da célula para cada espécie deve ser determinada empiricamente (Iida et al., 1991).

\subsubsection{Tamanho das Células}

O tamanho das células não parece ser um fator limitante para a transformação, por meio da biolística. Uma variedade de células animais e vegetais, de vários tamanhos e formatos, já foram transformadas, bem como microrganismos, medindo menos de $1 \mu \mathrm{m}$ (E. coli) e organelas citoplasmáticas (cloroplastos e mitocôndrias). Este parâmetro torna-se mais importante, na seleção do tamanho apropriado das micropartículas e da melhor distância da membrana carreadora até as células-alvos (Sanford et al., 1993).

\subsubsection{Densidade Celular}

A densidade celular é um importante parâmetro para a transformação, tanto de microrganismos, quanto de culturas de células em suspensão. Geralmente, camadas uniformes de células fornecem um número maior de alvos e apresentam melhor eficiência de transformação (Sanford et al., 1993). 


\subsubsection{Tratamento Pré e Pós Bombardeamento}

$\mathrm{O}$ tratamento dos explantes, no caso do bombardeamento in vitro, pode influir na freqüência de transferência de genes. $O$ incremento da pressão osmótica do meio de cultura das células, antes do bombardeamento, pode elevar significativamente a taxa de transformação, além de diminuir a variabilidade do sistema entre experimentos (Russel et al., 1992). O aumento da osmolaridade do meio evita a extrusão do protoplasma pela plasmólise das células, devido a diminuição da turgidez, assim como, aumenta a penetração das partículas (Sanford et al., 1993).

Os beneficios da introdução dos fatores osmóticos, no meio de cultura (manitol, sorbitol, etc.), também são observados em bactérias e fungos (Armaleo et al., 1990 e Sanford et al., 1993). O dessecamento das células, antes do bombardeamento e o uso de frascos/placas de cultura, que permitem trocas gasosas, são outros artificios usados para aumentar a eficiência do sistema (Vain et al., 1993). Estes resultados mostram que a alteração das condições fisiológicas das células provoca modificações, na eficiência do bombardeamento.

\subsubsection{Toxicidade do Tungstênio}

Em alguns casos, partículas de tungstênio são tóxicas para as células. Russel et al. (1992) demonstraram que partículas de tungstênio, adicionadas ao meio de cultura de células de tabaco, mesmo em concentrações 10 a 20 vezes menores que as liberadas em um bombardeamento, reduziram o crescimento celular. Em altas concentrações, o tungstênio pode causar extensiva morte celular (Russel et al., 1992). Tungstênio pode também acidificar, severamente, o meio de cultura. Apesar de não ter sido detectada nas células de tabaco, a acidificação pode causar sérios problemas para células pH sensitivas (Sanford et al., 1993).

Quando tungstênio for tóxico para um determinado tipo de célula, deve-se utilizar ouro ou outra partícula inerte. Em suspensão de células de tabaco, Russel et al. (1992) verificaram que o bombardeamento, com partículas de ouro em substituição ao tungstênio, triplicou a taxa de transformantes estáveis. 


\subsection{TRANSFERÊNCIA DE GENES EM CÉLULAS E TECIDOS ANIMAIS POR MEIO DA BIOLÍSTICA}

O primeiro trabalho de transferência de genes em animais apareceu em 1989, onde uma linhagem de células de camundongos foi transformada com o gene neo, que confere resistência ao antibiótico geneticina (Zelenin et al., 1989). Desde então, a biolística tem sido utilizada para a transformação de células em cultura, de órgãos isolados e de tecidos de animais vivos (Johnston et al., 1991; Yang et al., 1990 e Zelenin et al., 1991b). O potencial de aplicação desta técnica reside na viabilização da análise da expressão de genes e promotores tecidos-específicos, na produção de células e animais transgênicos e, principalmente, na terapia e imunização genéticas (Klein \& FitzpatrickMcElligott, 1993).

\subsubsection{TRANSFERÊNCIA DE GENES IN VITRO}

Apesar da fragilidade da membrana celular, a biolística tem-se mostrado muito eficiente na transferência de genes, em muitas culturas de células animais testadas. A expressão de genes repórteres já foi demonstrada, em linhagens de células derivadas do epitélio, endotélio, fibroblastos, glândula mamária, rim e linfócitos de camundongos, ratos e humanos (Burkholder et al., 1993; Fitzpatrick-McElligott, 1992; Yang et al., 1990 e Zelenin et al., 1989).

A expressão transiente de genes em cultura de células, utilizando diferentes construções gênicas, mostrou taxas de eficiência variando de 0,5 a 7,0\%. $\mathrm{O}$ comprimento relativo de promotores, $\mathrm{o}$ tipo de célula $\mathrm{e}$ as condições de bombardeamento, causaram variações na taxa de transformação (Yang et al., 1990 e Zelenin et al., 199lb). Não obstante a fragilidade das células de mamíferos, a viabilidade das células em cultura permaneceu alta (85 a 97\%), após o bombardeamento.

Esta técnica mostra-se verdadeiramente eficaz, quando usada para introduzir genes, em células ou tecidos animais, com os quais outras técnicas não 
lograram êxito. Tais células e tecidos incluem: linhagens de células de linfócitos de camundongos que infiltram tumor (Fitzpatrick-McElligot, 1992), preadipócitos, macrófagos e células pré-B (Heiser, 1994), células primárias derivadas de glândulas mamárias (Yang et al., 1990) e células primárias derivadas de tecido cerebral (Jiao et al., 1993). Genes também têm sido liberados, diretamente, em explantes de tecidos sólidos, tais como: glândulas mamárias, figado e rim (Thompson et al., 1993 e Zelenin et al., 1991b).

Clones transformantes estáveis, de várias linhagens de células de mamíferos, têm sido obtidos, após o bombardeamento com o gene neo. A freqüência destes transformantes estáveis variou de $6 \times 10^{-4}$ para células MCF=7 (linhagem celular de carcinoma de mama de humanos) (Yang et al., 1990), CHO (células do ovário de hamster chineses) (Fitzpatrick-McElligot, 1992) e NIH3T3 (linhagem celular de camundongos) (Zelenin et al., 1989) até $1,7 \times 10^{-4}$ nas linhagens de linfócitos $\mathrm{T}$ (Fitzpatrick-McElligot, 1992).

O bombardeamento de tecidos foi também utilizado, como ferramenta para a caracterização de promotores específicos, em culturas primárias de células epiteliais mamárias de ratos (Thompson et al., 1993) e em explantes da glândula mamária, figado e rim de ratos e camundongos (Zelenin et al., 1991b).

A biolística também pode ser utilizada como uma estratégia eficiente para a terapia genética, por meio da transferência de genes em células e tecido in vitro, seguida por transplantes destas células transformadas no órgão de origem. Jiao et al. (1993) transformaram cultura de células primárias de cérebro fetais de ratos com o gene que codifica para a tirosina hidroxilase, uma enzima deficiente em pacientes com Mal de Parkinson. $\mathrm{O}$ tecido cerebral fetal é, então, transplantado na região caudal e intracortical do cérebro de ratos adultos. Após duas semanas, $2 \%$ das células transplantadas apresentaram atividade enzimática. 


\subsubsection{Transferência de Genes IN VIVO}

A habilidade de transferir DNA, diretamente, em células somáticas de animais vivos, abre uma nova possibilidade de aplicação da biolística (Johnston et al., 1991; Yang et al., 1990 e Williams et al., 1991). Diversas construções gênicas têm sido transferidas para tecidos somáticos de animais vivos, por meio de aparelhos, que utilizam pólvora (Johnston et al., 1991 e Zelenin et al., 1991b, 1997), descarga elétrica (Cheng et al., 1993 e Yang et al., 1990), pressão de gás hélio (Johnston et al., 1991; Kerr et al., 1996; Li et al., 1995; Williams et al., 1991 e Yoshida et al., 1997) e nitrogênio (Muramatsu et al., 1997a, b e 1998).

Inúmeros trabalhos têm demonstrado a expressão de genes repórteres em órgãos, como: pele dos membros e do abdômen, derme, figado, orelha, músculo, pâncreas e testículo de camundongos e ratos (Cheng et al., 1993; Johnston et al., 1991; Muramatsu et al., 1997b, Williams et al., 1991; Yang et al., 1990; Yoshida et al., 1997 e Zelenin et al., 1991b, 1997); epiderme, derme, figado e músculo de coelho e macaco rhesus (Cheng et al., 1993); glândula mamária e músculo de ovelha (Kerr et al., 1996); oviduto e figado de galinhas poedeiras (Muramatsu et al., 1998).

Utilizando o gene da luciferase, sob o controle do promotor da $\beta$-actina, Williams et al. (1991) e Cheng et al. (1993), mediram os níveis da expressão do transgene, após o bombardeamento de camundongos e ratos vivos. A epiderme da pele abdominal e o figado mostraram os mais altos níveis de expressão do transgene. A profundidade da penetração também variou, com o tipo de tecido. Por exemplo, na epiderme, as micropartículas foram encontradas, somente nas primeiras camadas celulares; em orelhas bombardeadas, as micropartículas atingiram a derme e algumas camadas da cartilagem; e no figado, as partículas restringiam-se às 10 primeiras camadas celulares. A expressão na pele foi observada, em 10 a $20 \%$ das células bombardeadas (Williams et al., 1991 e Yang et al., 1990), sendo que a expressão do transgene persistiu, até o quarto dia, após o bombardeamento. Dos tecidos bombardeados, o figado manteve a expressão, por 14 a 23 dias (Williams et al., 1991) e a derme da pele abdominal, por um ano e meio (Cheng et al., 1993). Células musculares bombardeadas, com o gene da 
cloranfenicol acetil transferase (Yang et al., 1990) ou com o gene da luciferase (Cheng et al., 1993) ou com o gene da $\beta$-galactosidase (Zelenin et al., 1997), apresentaram baixo nível de expressão inicial, com apenas 1 a 3\% das células expressando o transgene (Yang et al., 1990). Zelenin et al. (1997) observaram que somente os músculos superficiais apresentavam expressão do transgene, devido à limitada penetração das partículas. Testes com mistura de partículas de ouro e tungstênio mostraram que quanto maior a concentração de partículas de tungstênio na mistura, maior a intensidade da expressão do transgene. Uma proporção de ouro e tungstênio, de 1:4, atingiu uma profundidade de 4 mm e evidenciou a presença da atividade do transgene por 3 meses. A expressão do gene da distrofia humana também foi detectada em células musculares, persistindo até 2 meses, após o bombardeamento (Zelenin et al., 1997). Estes trabalhos relataram danos mínimos aos tecidos bombardeados, mesmo aos mais frágeis.

A aplicabilidade da biolística para outras espécies de mamíferos, que não murinos, foi avaliada, por meio do bombardeados, in vivo, da epiderme e derme abdominal, orelha, figado e músculo de coelhos, macaco rhesus, cobaias, bovinos e ovelhas (Cheng et al.,1993; Rech et al., 1996 e Zelenin et al., 1997). As células, expressando o transgene, apresentavam-se homogeneamente distribuídas, da epiderme até o tecido cartilaginoso da orelha de bovinos (Rech et al., 1996). A expressão transiente da luciferase foi detectada, em todos os tecidos dos dois animais testados, sendo que a atividade da luciferase na epiderme de macaco foi mais alta que em coelhos (Cheng et al., 1993).

O bombardeamento de partículas, in vivo, também pode ser utilizado para a análise da atividade de promotores, em diferentes tecidos. Em ratos, a atividade do promotor do citomegalovírus (CMV) foi, consistentemente, o mais alto em cada tecido bombardeado (epiderme, derme, músculo, figado e pâncreas), enquanto que outros quatro promotores virais e cinco celulares apresentaram atividade tecido-específico. Em células musculares, os promotores SV40 ("Simian virus 40”) e RSV ("Rous sarcoma virus") apresentaram altos níveis de expressão, comparáveis ao CMV (Cheng et al., 
1993). O mesmo foi observado por Zelenin et al. (1997) em músculos esqueléticos de camundongos.

A análise da funcionalidade de promotores tecidos-específicos também pode ser realizada, por meio da biolística. Muramatsu et al. (1998) testaram várias regiões do promotor do gene da ovalbumina, no oviduto e figado de galinhas poedeiras. Os resultados demonstraram que, no oviduto, a expressão do gene repórter foi alta, independente do tamanho do promotor, enquanto que, no figado, promotores maiores suprimiam substancialmente a expressão do gene repórter. Os autores propuseram a presença de um elemento silenciador tecido-específico no figado, mas ausente no oviduto.

Outra aplicação da biolística para a transferência de genes, in vivo, é a liberação de genes, que codificam antígenos para a produção de anticorpos. Em consequêencia, novas expectativas surgem, no campo da imunização genética (Oliveira et al., 1999 e Tang et al., 1992).

\subsubsection{TransferênCia de Genes em OvOS E EMbriõeS}

Ovos fertilizados de três espécies de peixe (Misgurnus fossilis, Salmo gairdneri, Brachydanio rerio) foram bombardeados, com os genes lacZ e neo (Zelenin et al., 1991a). Sob as condições utilizadas neste experimento, cerca de $70 \%$ dos embriões sobreviveram ao bombardeamento. Três dias após o bombardeamento, $5 \%$ dos embriões apresentavam atividade da enzima $\beta$-gal. Os embriões, que apresentavam o gene de resistência à geneticina, sobreviveram por mais tempo que os controles. Ainda dentro dos vertebrados, a expressão transiente do gene lacZ foi detectada em ovócitos de Xenopus (Cheng \& Joho, 1994).

Embriões de drosófilas foram também transformados, por meio da biolística (Baldarelli \& Lengyel, 1990 e Mialhe \& Miller, 1994). Altos níveis de expressão transiente do gene repórter $l a c Z$, sob o controle do promotor da actina $5 \mathrm{C}$, foram verificados nos embriões. Também foi obtido um único embrião, com as células 
germinativas transformadas. A maior vantagem, nesta aplicação, é a possibilidade de bombardeamento simultâneo de muitos ovos e embriões, o que não ocorre com a microinjeção, que é uma técnica precisa, mas trabalhosa (Baldarelli \& Lengyel, 1990).

\subsubsection{TRANSFERÊNCIA DE GENES EM INVERTEBRADOS}

A aplicação, a viabilidade e a efetividade da biolística, em duas espécies de protozoários (Leishmania e Crithidia fasciculata), foram demonstradas em dois trabalhos (Sbicego et al., 1998 e Vainstein et al., 1994). Com o bombardeamento do gene neo, aplicado nas duas espécies, os autores obtiveram tanto expressão transiente quanto estável.

O gene da luciferase, sob o controle do promotor da proteína de choque térmico de Drosophila melanogaster (hsp 70), foi utilizado para o bombardeamento de embriões de crustáceos (Gendreau et al., 1995) e de ostras (Cadoret et al., 1997). Os resultados mostraram que a expressão da enzima foi transiente e que persistiu somente por 24 horas, após o bombardeamento.

\subsubsection{TRANSFERÊNCIA DE GENES EM EMBRIÕES de GaLINHA IN OVO}

Dois trabalhos reportaram a transferência de genes em embriões de galinhas, por meio da biolística. Li et al. (1995) transformaram as células germinativas primordiais de embriões, de 50 horas de incubação, com um vetor contendo os genes neo e o que codifica para a ovalbumina. Após a incubação destes ovos, até sua maturidade sexual, foi verificada a presença do DNA exógeno nos espermatozóides dos frangos nascidos. Estes foram cruzados com galinhas normais e, dos 45 indivíduos G1 nascidos, 10 apresentavam o transgene (22\%). Na maioria dos casos, o DNA exógeno desapareceu da prole Gl, quando seus indivíduos alcançaram a maturidade sexual, sugerindo que, nestes casos, não houve integração e a transmissão do transgene foi epissomal. A taxa de sobrevivência foi de $20 \%$. 
Muramatsu et al. (1997a) bombardearam embriões de galinha, de 48 horas de incubação, com o gene lacZ, sob o controle dos promotores do RSV-LTR ("Rous sarcoma virus - long terminal repeat") e do gene da $\beta$-actina de galinhas. Utilizando partículas de tungstênio e 285 psi de nitrogênio, eles obtiveram uma taxa de sobrevivência de $42,9 \%$ e uma eficiência de transformação de $45,8 \%$. A expressão da enzima foi transiente e não foi verificada a integração do gene exógeno no genoma. 


\section{Cap. I: TRANSFERENCIA DE DNA IN SITU EM EMBRIÕES DE GALINHA POR MEIO DA BIOLÍSTICA (In situ DNA transfer to chicken embryos by biolistics)}

RIBEIRO, L.A.; AZEVEDO, J.L.; ARAGÃO, F.J.L.; RECH, E.L.; SCHMIDT, G.S.; COUTINHO, L.L. In situ DNA transfer to chicken embryos by biolistic. Genetics and Molecular Biology, 1999 (aceito para publicação). 


\title{
3. TRANSFERÊNCIA DE DNA IN SITU EM EMBRIÕES DE GALINHA POR MEIO DA BIOLÍSTICA \\ (In situ DNA transfer to chicken embryos by biolistics)
}

\begin{abstract}
RESUMO
Ovos fertilizados de galinha foram bombardeados através da técnica da biolística. Expressão transiente do gene lacZ, sob o controle do promotor humano citomegalovírus, foi verificada após a transferência in situ. Diferentes níveis de pressão de gás hélio, vácuo e tipos de partículas foram testados. A taxa de sobrevivência aumentou à medida que a velocidade das partículas diminuiram, entretanto, o nível de expressão foi menor. Os melhores resultados, combinando taxa de sobrevivência e expressão, foram obtidos com partículas de ouro, 600 psi de hélio e $600 \mathrm{mmHg}$ de vácuo. Nestas condições, todos os embriões bombardeados apresentaram atividade da $\beta$ galactosidase, indicando que esta técnica é eficiente para a transformação de embriões de galinhas.
\end{abstract}

\section{SUMMARY}

Fertilized chicken eggs were bombarded with a biolistic device. Transient expression of the lacZ gene under the control of a human cytomegalovirus (CMV) promoter was assessed after in situ gene transfer using this approach. The influence of different pressures, vacuum levels and particles was tested. Survival rate improved as particle velocity decreased, but resulted in lower levels of expression. The best survival and expression were obtained with gold particles, a helium gas pressure of $600 \mathrm{psi}$ and a vacuum of $600 \mathrm{mmHg}$. Under these conditions, all bombarded embryos showed $\beta$ galactosidase activity, indicating that this was an effective method for transformation of chicken embryos. 


\subsection{INTRODUÇÃO}

A técnica de transferência de DNA tem permitido avanços significativos na expressão de genes exógenos. Animais transgênicos têm sido utilizados tanto como modelos de estudos das funções dos genes, como para a produção de proteínas de alto valor comercial.

A técnica de microinjeção é a mais bem estudada forma de produção de mamíferos transgênicos, mas há consideráveis problemas na sua aplicação em aves (Li et al., 1995). A principal dificuldade deve-se ao fato que, no momento da ovoposição, o embrião já possui mais de 60.000 células. Para resolver este problema, a estratégia utilizada é a transformação de pronúcleos de ovos recém-fertilizados.

Outros métodos utilizados com sucesso em aves são a transfecção de células embrionárias indiferenciadas utilizando-se vetores retrovirais, lipofecção in ovo, eletroporação e biolística (Muramatsu et al., 1997a). Quando expressão gênica estável e prole transgênica são desejáveis, a técnica de transfecção de células embrionárias indiferenciadas, utilizando-se vetores retrovirais, é a mais conveniente e a mais empregada (Petitte et al., 1990). As células embrionárias indiferenciadas que têm sido mais utilizadas são células da blastoderme ou células germinativas primordiais. Quando as células da blastoderme são utilizadas, estas são transfectadas in ovo com retrovírus e, os embriões quiméricos resultantes, que contêm os genes exógenos em suas células germinativas, são capazes de gerar proles transgênicas (Bosselman et al., 1989). Quando as células germinativas primordiais são utilizadas, o DNA exógeno é inserido nas células previamente isoladas, utilizando-se retrovírus defectivos. Estas células, então, são transferidas para embriões receptores, colonizando as gônadas. Os embriões quiméricos resultantes serão capazes de originar uma prole transgênica (Vick et al., 1993a).

Há, entretanto, dois problemas com estes métodos. Primeiro, a manipulação dos embriões é complicada, aumentando a taxa de mortalidade, especialmente nos primeiros estádios de incubação. Segundo, é muito dificil predizer o destino potencial das células da blastoderme e, consequentemente, calcular a probabilidade destas células colonizarem as gônadas (Petitte et al., 1990). 
Quando deseja-se expressão transiente, os métodos de lipofecção in ovo, eletroporação e biolística têm sido utilizados para transfectar embriões de galinha (Muramatsu et al., 1997a). Em particular, a biolística tem sido bastante empregada em uma variedade de tecidos animais (Yang et al., 1990; Williams et al., 1991, Klein \& Fitzpatrick-McElligott, 1993; Rech et al., 1996).

O presente trabalho propõe o desenvolvimento e a otimização de um método para a introdução e expressão transiente de genes em embriões de galinha bombardeados in situ.

\subsection{MATERIAIS E MÉTODOS}

\section{Embriões de galinha}

Ovos fertilizados de galinhas foram incubados a $38^{\circ} \mathrm{C}$ por 30 horas. Embriões no estádio 10 de desenvolvimento (Hamburger \& Hamilton, 1951) foram bombardeados in situ. Uma pequena abertura $(10 \mathrm{a} 15 \mathrm{~mm})$ foi feita na superficie mais robusta das cascas destes ovos, expondo, desta forma, os embriões para o bombardeamento. Após o bombardeamento, as cascas foram seladas com filme PVC e os ovos incubados por mais 24 horas em uma estufa a $38^{\circ} \mathrm{C}$.

\section{Plasmídeo}

O plasmídeo utilizado foi o pCMVß (CLONTECH, Palo Alto, CA, USA), que contém o gene da $\beta$-galactosidase $(\beta$-gal) de Escherichia coli sob o controle do promotor do citomegalovírus humano (CMV). O protocolo para a precipitação do plasmídeo em partículas de ouro ou tungstênio foi o descrito por Aragão et al. (1996).

\section{Bombardeamento}

Um aparelho de alta pressão de gás hélio foi utilizado para 0 bombardeamento dos embriões. As distâncias utilizadas foram: 0,6 cm entre os discos de 
ruptura e o macrocarreador; $2,0 \mathrm{~cm}$ entre o macrocarreador e a tela de retenção; e 11,0 cm entre o macrocarreador e o embrião.

Foram testados três tipos de partículas para a precipitação do plasmídeo: ouro com um diâmetro de 1,5 a 3,0 $\mu \mathrm{m}$ (Aldrich no. 32.658-5) e tungstênio com

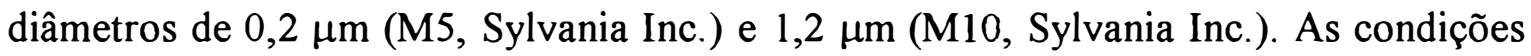
de bombardeamento, utilizando-se ouro, foram: com vácuo de $600 \mathrm{mmHg}$, foram testadas as pressões de 400, 500 e 600 psi de gás hélio; com vácuo de $400 \mathrm{mmHg}$, foram testadas as de 800, 900, 1000 e 1500 psi de hélio. Com partículas de tungstênio de 0,2 $\mu \mathrm{m}$, foram testadas as pressões de 600, 900 e 1200 psi, com vácuo de $600 \mathrm{mmHg}$. Com partículas de tungstênio de 1,2 $\mu \mathrm{m}$, foram testadas as pressões de 600 e 900 psi, com vácuo de $600 \mathrm{mmHg}$.

O posicionamento dos embriões no momento do bombardeamento, em relação ao centro do cone de dispersão das partículas (zona de morte), foi calculado com o auxílio de uma caneta a laser, que delimitou o centro. Os embriões foram colocados em duas posições: na zona de morte e a $1 \mathrm{~cm}$ de distância da zona de morte. A mira dos embriões com caneta a laser só foi realizada quando utilizou-se partículas de tungstênio.

\section{Atividade da $\beta$-galactosidase}

A atividade da $\beta$-galactosidase foi detectada por coloração histoquímica. Vinte e quatro horas após o bombardeamento, os embriões foram fixados em uma solução de formaldeído $4 \%$ por 5 minutos a $4^{\circ} \mathrm{C}$. Os embriões foram corados, durante 4 horas a $37^{\circ} \mathrm{C}$, com um substrato cromogênico contendo: $100 \mathrm{mM}$ de fosfato de sódio, $1,3 \mathrm{mM} \mathrm{MgCl}_{2}, 3 \mathrm{mM} \mathrm{K} \mathrm{Fe}_{4}(\mathrm{CN})_{6}, 3 \mathrm{mM} \mathrm{K}{ }_{3} \mathrm{Fe}(\mathrm{CN})_{6}$ e $1 \mathrm{mg} / \mathrm{ml}$ X-gal (5-bromo-4cloro-3-indolil- $\beta$-galactosidase). A detecção da expressão da $\beta$-galactosidase foi realizada através de análise histoquímica, baseada na hidrólise do X-gal. Os produtos da hidrólise são convertidos a índigo insolúvel. A cor azul gerada por essa hidrólise facilita a localização da atividade da $\beta$-gal nos embriões transformados. A transformação foi verificada através da presença ou ausência de pontos azuis (unidades de expressão), que representam uma célula ou conjunto de células que estão expressando o gene. 
Independente do número de unidades de expressão, todos os embriões que apresentavam pontos azuis foram considerados nas análises. Os embriões que apresentaram atividade gênica foram classificados em duas categorias de expressão: 1) expressão nas células do corpo do embrião e/ou no tecido extra-embrionário (expressão total), 2) expressão nas células do corpo do embrião.

Embriões não bombardeados foram utilizados como controles negativos e não apresentaram coloração alguma. A sobrevivência dos embriões, determinada pela presença de batimento cardíaco, foi observada 24 horas após o bombardeamento.

\subsection{RESULTADOS}

Neste trabalho, uma série de experimentos foram conduzidos para otimizar a transferência de DNA para embriões de galinha, visto que cada espécie ou tipo celular requer diferentes condições (Gendreau et al., 1995; Zelenin et al., 1991b; Williams et al., 1991).

Nos primeiros experimentos conduzidos foram utilizados partículas de ouro, vácuo de $600 \mathrm{mmHg}$ e pressões de 400, 500 e 600 psi. Foram bombardeados 36 embriões, sendo 10 com 400 psi, 10 com 500 psi e 16 com 900 psi (Tabela 1). Os resultados obtidos mostraram que, aproximadamente, $30 \%$ dos embriões sobreviveram as três pressões utilizadas. Aproximadamente, 53\% dos embriões apresentaram expressão da $\beta$-galactosidase nas células do corpo, sendo que 19,4\% apresentaram mais de 100 unidades de expressão (pontos azuis). O número de gemas furadas foi em torno de $30 \%$ para as três condições. 
Tabela 1. Efeito da pressão de hélio na expressão da $\beta$-gal em embriões bombardeados com partículas de ouro e vácuo de $600 \mathrm{mmHg}$.

\begin{tabular}{ccccccc}
\hline \multirow{2}{*}{$\begin{array}{c}\text { Pressão } \\
\text { de Hélio } \\
\text { (psi) }\end{array}$} & $\mathrm{n}$ & & $\begin{array}{c}\text { Eficiência de transformação } \\
\text { \%ombriões } \\
\text { com expressão } \\
\text { total }^{1}\end{array}$ & $\begin{array}{c}\text { \% embriões com } \\
\text { expressão nas } \\
\text { células do corpo }\end{array}$ & $\begin{array}{c}\text { Gemas } \\
\text { furadas (\%) }\end{array}$ & $\begin{array}{c}\text { Taxa de } \\
\text { sobrevivência } \\
\text { (\%) }\end{array}$ \\
\hline 400 & 10 & $80,0(8 / 10)^{2}$ & $50,0(5 / 10)^{3}$ & $20,0(2 / 10)^{4}$ & $40,0(4 / 10)^{5}$ \\
500 & 10 & $60,0(6 / 10)$ & $50,0(5 / 10)$ & $40,0(4 / 10)$ & $20,0(2 / 10)$ \\
600 & 16 & $68,7(11 / 16)$ & $56,2(9 / 16)$ & $31,2(5 / 16)$ & $31,2(5 / 16)$ \\
\hline
\end{tabular}

${ }^{1}$ Embriões com expressão da $\beta$-gal nas células do corpo e/ou no tecido extra-embrionário.

${ }^{2}$ No. de embriões expressando $\beta$-gal /No. total de embriões bombardeados.

${ }^{3}$ No. de embriões expressando $\beta$-gal nas células do corpo/No. total de embriões bombardeados.

${ }_{5}^{4}$ No. de gemas estouradas no momento do bombardeamento/ No. total de ovos bombardeados.

${ }^{5}$ No. embriões com coração batendo 24 horas após o bombardeamento/No. total de embriões bombardeados.

Com o objetivo de reduzir o dano aos embriões e aumentar a sobrevivência, foi realizado uma nova série de experimentos, utilizando-se menor vácuo (400 mmHg ao invés de $600 \mathrm{mmHg}$ ). Neste caso, a resistência do ar foi maior e a velocidade das partículas reduzida. Foram bombardeados 48 embriões, sendo 14 com 600 psi, 11 com 800 psi, 6 com 900 psi, 11 com 1000 psi e 6 com 1500 psi (Tabela 2). Não foram testadas pressões maiores, pois muitas gemas romperam-se com 1500 psi. A sobrevivência dos embriões foi maior do que a do experimento anterior, alcançando $50 \%$ em média. A pressão de 1500 psi foi bastante prejudicial aos embriões, sendo que somente um embrião de seis sobreviveu ao bombardeamento. A eficiência de transformação, no entanto, foi pequena. Somente um único embrião com 20 pontos azuis nas células do corpo foi obtido na pressão de 1500 psi. Nas demais pressões, expressão no tecido extra-embrionário foi observada em $28,6 \%$ dos embriões bombardeados. Portanto, tentativas em aumentar a taxa de sobrevivência, reduzindo o vácuo, foi contrabalançada por uma redução na expressão e, aumento na pressão de hélio, como medida para melhorar a baixa eficiência de transformação, resultou na redução da sobrevivência dos embriões. 
Tabela 2. Efeito da pressão de hélio na expressão da $\beta$-gal em embriões bombardeados com partículas de ouro e vácuo de $400 \mathrm{mmHg}$.

\begin{tabular}{|c|c|c|c|c|c|}
\hline \multirow[b]{2}{*}{$\begin{array}{l}\text { Pressão } \\
\text { de Hélio } \\
\text { (em psi) }\end{array}$} & \multirow[b]{2}{*}{$\mathrm{n}$} & \multicolumn{2}{|c|}{ Eficiência de transformação } & \multirow[b]{2}{*}{$\begin{array}{c}\text { Gemas } \\
\text { furadas }(\%)\end{array}$} & \multirow{2}{*}{$\begin{array}{c}\text { Taxa de } \\
\text { sobrevivência } \\
(\%)\end{array}$} \\
\hline & & $\begin{array}{c}\% \text { embriões } \\
\text { com expressão } \\
\text { total }^{1}\end{array}$ & $\begin{array}{l}\text { \% embriões com } \\
\text { expressão nas } \\
\text { células do corpo }\end{array}$ & & \\
\hline 600 & 14 & $21,4(3 / 14)^{2}$ & -- & -- & $78,6(11 / 14)^{5}$ \\
\hline 800 & 11 & $27,3(3 / 11)$ & -- & $27,3(3 / 11)^{4}$ & $45,4(5 / 11)$ \\
\hline 900 & 6 & $50,0(3 / 6)$ & -- & - & $33,3(2 / 6)$ \\
\hline 1000 & 11 & $27,3(3 / 11)$ & -- & $18,2(2 / 11)$ & $72,7(8 / 11)$ \\
\hline 1500 & 6 & $66,7(4 / 6)$ & $16,7(1 / 6)^{3}$ & $33,3(2 / 6)$ & $16,7(1 / 6)$ \\
\hline
\end{tabular}

${ }^{1}$ Embriões com expressão da $\beta$-gal nas células do corpo e/ou no tecido extra-embrionário.

${ }^{2}$ No. de embriões expressando $\beta$-gal /No. total de embriões bombardeados.

${ }^{3}$ No. de embriões expressando $\beta$-gal nas células do corpo/No. total de embriões bombardeados.

${ }^{4}$ No. de gemas estouradas no momento do bombardeamento/ No. total de ovos bombardeados.

5 No. embriões com coração batendo 24 horas após o bombardeamento/No. total de embriões bombardeados.

A Figura 1 mostra uma comparação entre embriões bombardeados com diferentes níveis de vácuo, utilizando-se partículas de ouro e 600 psi de hélio. $O$ embrião bombardeado com $600 \mathrm{mmHg}$ apresentou um número maior de unidades de expressão que o bombardeado com $400 \mathrm{mmHg}$, porém mostrou um desenvolvimento anormal dos tecidos.

Com o objetivo de aumentar a sobrevivência dos embriões, partículas de tungstênio de $0,2 \mu \mathrm{m}$ foram testadas, pois o tamanho, formato e material das partículas influenciam a eficiência de transformação (Klein et al., 1992). A Tabela 3 mostra os resultados obtidos com $600 \mathrm{mmHg}$ de vácuo e pressões de 600, 900 e 1200 psi de hélio. Pressões mais altas não foram utilizadas devido a alta taxa de gemas furadas $(66,7 \%)$. A taxa de sobrevivência média nas três pressões foi de $42 \%$. A pressão de 1200 psi causou o maior decréscimo na taxa de sobrevivência. Somente um dos nove embriões bombardeados sobreviveu. Em todas as pressões testadas, o número de unidades de expressão foi pequeno e nenhum embrião apresentou mais de 10 unidades de expressão nas células do corpo. 

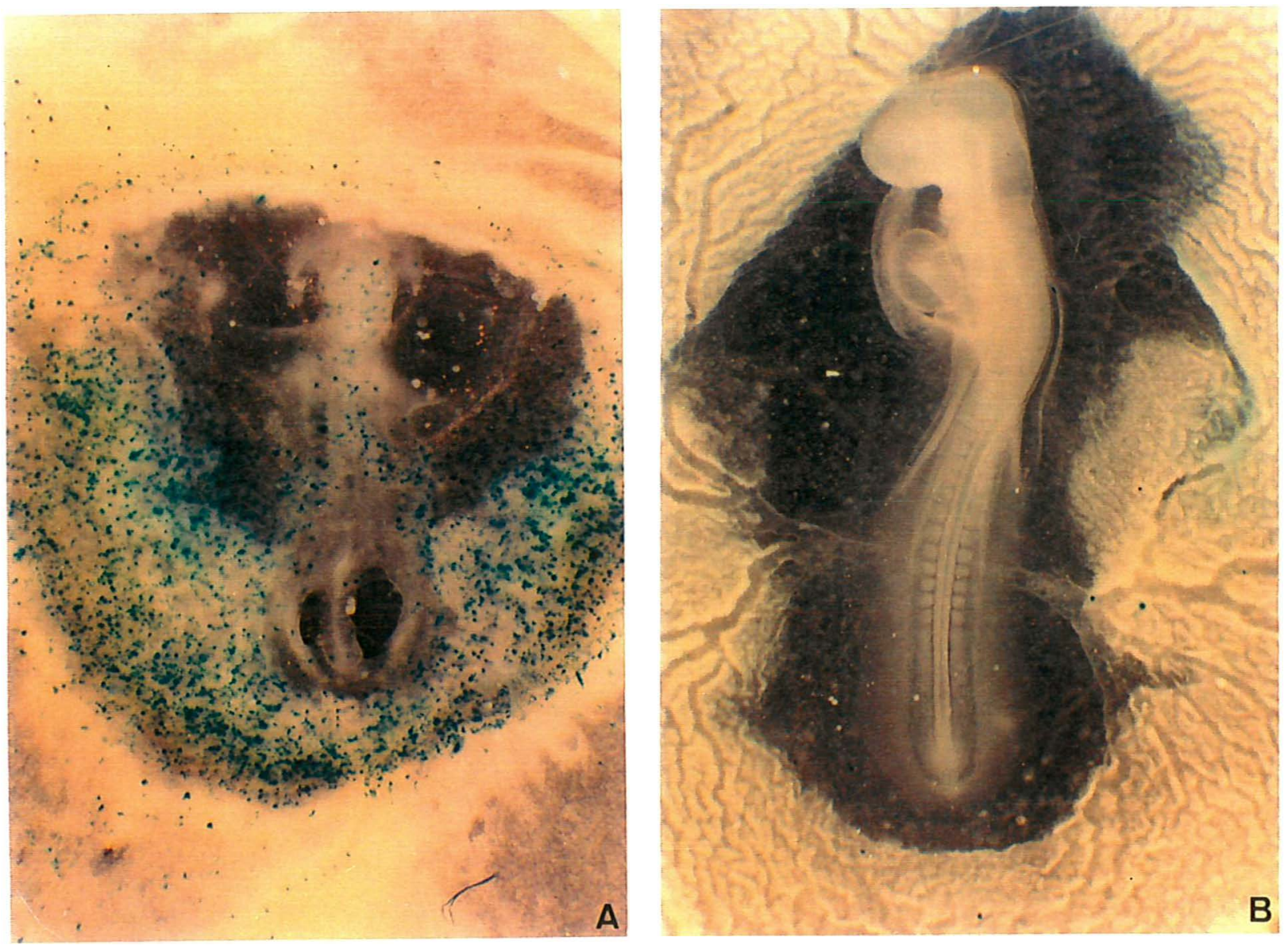

Figura 1. Embriōes bombardeados com partículas de ouro, 600 psi de gás hélio e 600 $\mathrm{mmHg}(\mathrm{A})$ ou $400 \mathrm{mmHg}$ (B) de vácuo. Os pontos azuis indicam expressão da $\beta$-galactosidase. (A, 16X; B, $11 X)$. 
Tabela 3. Efeito da pressão de hélio na expressão da $\beta$-gal em embriões bombardeados com partículas de tungstênio M5 e vácuo de $600 \mathrm{mmHg}$.

\begin{tabular}{|c|c|c|c|c|c|}
\hline \multirow[b]{2}{*}{$\begin{array}{l}\text { Pressão } \\
\text { de Hélio } \\
\text { (em psi) }\end{array}$} & \multirow[b]{2}{*}{$\mathrm{n}$} & \multicolumn{2}{|c|}{ Eficiência de transformação } & \multirow[b]{2}{*}{$\begin{array}{c}\text { Gemas } \\
\text { furadas (\%) }\end{array}$} & \multirow{2}{*}{$\begin{array}{c}\text { Taxa de } \\
\text { sobrevivência } \\
(\%)\end{array}$} \\
\hline & & $\begin{array}{c}\% \text { embriões } \\
\text { com expressão } \\
\text { total }^{1}\end{array}$ & $\begin{array}{l}\text { \% embriões com } \\
\text { expressão nas } \\
\text { células do corpo }\end{array}$ & & \\
\hline 600 & 9 & $88,9(8 / 9)^{2}$ & $33,3(3 / 9)^{3}$ & $11,1(1 / 9)^{4}$ & $66,7(6 / 9)^{5}$ \\
\hline 900 & 15 & $60,0(9 / 15)$ & $13,3(2 / 15)$ & $33,3(5 / 15)$ & $46,7(7 / 15)$ \\
\hline 1200 & 9 & $22,2(2 / 9)$ & -- & $66,7(6 / 9)$ & $11,1(1 / 9)$ \\
\hline
\end{tabular}

${ }^{1}$ Embriões com expressão da $\beta$-gal nas células do corpo e/ou no tecido extra-embrionário.

${ }^{2}$ No. de embriões expressando $\beta$-gal /No. total de embriões bombardeados.

${ }^{3}$ No. de embriões expressando $\beta$-gal nas células do corpo/No. total de embriões bombardeados.

${ }^{4}$ No. de gemas estouradas no momento do bombardeamento/ No. total de ovos bombardeados.

${ }^{5}$ No. embriões com coração batendo 24 horas após o bombardeamento/No. total de embriões bombardeados.

Diante da persistência da baixa eficiência de transformação, passamos a considerar que as partículas de $0,2 \mu \mathrm{m}$, não atingiam a velocidade necessária para penetrar as células, em função de sua pequena massa. Conduzimos, então, um outro experimento, utilizando partículas de tungstênio de maior tamanho $(1,2 \mu \mathrm{m})$. Foram bombardeados seis embriões com 600 psi de hélio e $600 \mathrm{mmHg}$ de vácuo. Uma mira a laser também foi adotada para demarcar o centro do cone de dispersão das partículas. Os embriões foram posicionados debaixo do ponto vermelho gerado pela caneta a laser, ou seja, diretamente no centro do cone. A eficiência de transformação foi de $100 \%$. Os seis embriões bombardeados apresentaram expressão nas células do corpo. Entretanto, o número de pontos azuis não foi muito grande, com somente $50 \%$ dos embriões apresentando mais de 100 unidades de expressão nas células do corpo. A taxa de sobrevivência foi baixa $(16,7 \%)$, sendo que somente um embrião sobreviveu ao bombardeamento. $\mathrm{O}$ desenvolvimento normal dos tecidos e órgãos foi severamente afetado. Estes resultados indicaram que o posicionamento dos embriões no centro do cone de dispersão das partículas deveria ser evitado.

Um último experimento foi conduzido modificando-se o posicionamento dos embriões para $1 \mathrm{~cm}$ de distância do centro do cone de dispersão das partículas. Dezoito embriões foram bombardeados sob vácuo de $600 \mathrm{mmHg}$, seis com 600 psi e 12 
com 900 psi (Tabela 4). As taxas de sobrevivência foram de 33,3\% e 16,6\%, em embriões bombardeados com 600 psi e 900 psi, respectivamente. Na pressão de 900 psi, $58,3 \%$ das gemas romperam-se no momento do bombardeamento. A eficiência de transformação foi de $66,7 \%$ para os embriões bombardeados com 600 psi e $41,7 \%$ para os bombardeados com 900 psi.

Tabela 4. Efeito da pressão de hélio na expressão da $\beta$-gal em embriões posicionados a 1 cm de distância da zona de morte, utilizando-se partículas de tungstênio M10 e vácuo de $600 \mathrm{mmHg}$.

\begin{tabular}{|c|c|c|c|c|c|}
\hline \multirow[b]{2}{*}{$\begin{array}{l}\text { Pressão } \\
\text { de Hélio } \\
\quad \text { (psi) }\end{array}$} & \multirow[b]{2}{*}{$\mathrm{n}$} & \multicolumn{2}{|c|}{ Eficiência de transformação } & \multirow[b]{2}{*}{$\begin{array}{c}\text { Gemas } \\
\text { furadas }(\%)\end{array}$} & \multirow[b]{2}{*}{$\begin{array}{c}\text { Taxa de } \\
\text { sobrevivência } \\
(\%)\end{array}$} \\
\hline & & $\begin{array}{c}\text { \% embriões } \\
\text { com expressão } \\
\text { total }^{1}\end{array}$ & $\begin{array}{l}\% \text { embriões com } \\
\text { expressão nas } \\
\text { células do corpo }\end{array}$ & & \\
\hline 600 & 6 & $66,7(4 / 6)^{2}$ & $16,7(1 / 6)^{3}$ & $33,3(2 / 6)^{4}$ & $33,3(2 / 6)^{5}$ \\
\hline 900 & 12 & $41,7(5 / 12)$ & $25,0(3 / 12)$ & $58,3(7 / 12)$ & $16,7(2 / 12)$ \\
\hline
\end{tabular}

${ }^{1}$ Embriões com expressão da $\beta$-gal nas células do corpo e/ou no tecido extra-embrionário.

${ }^{2}$ No. de embriões expressando $\beta$-gal /No. total de embriões bombardeados.

${ }^{3}$ No. de embriões expressando $\beta$-gal nas células do corpo/No. total de embriões bombardeados.

${ }^{4}$ No. de gemas estouradas no momento do bombardeamento/ No. total de ovos bombardeados.

${ }^{5}$ No. embriões com coração batendo 24 horas após o bombardeamento/No. total de embriões bombardeados.

Uma comparação entre embriões bombardeados com diferentes partículas de tungstênio é apresentada na Figura 2. Os embriões bombardeados com tungstênio de 0,2 $\mu \mathrm{m}$ apresentaram menor número de unidades de expressão, quando comparados aos bombardeados com partículas de maior tamanho $(1,2 \mu \mathrm{m})$.

O posicionamento dos embriões em relação ao centro do cone de dispersão das partículas, foi um parâmetro importante considerado nestes experimentos, visto que embriões posicionados no centro sofreram sérios danos no desenvolvimento dos tecidos. Os embriões bombardeados com partículas de maior tamanho e a $1 \mathrm{~cm}$ de distância do centro do cone de dispersão apresentaram desenvolvimento normal dos tecidos e um número intermediário de unidades de expressão. 


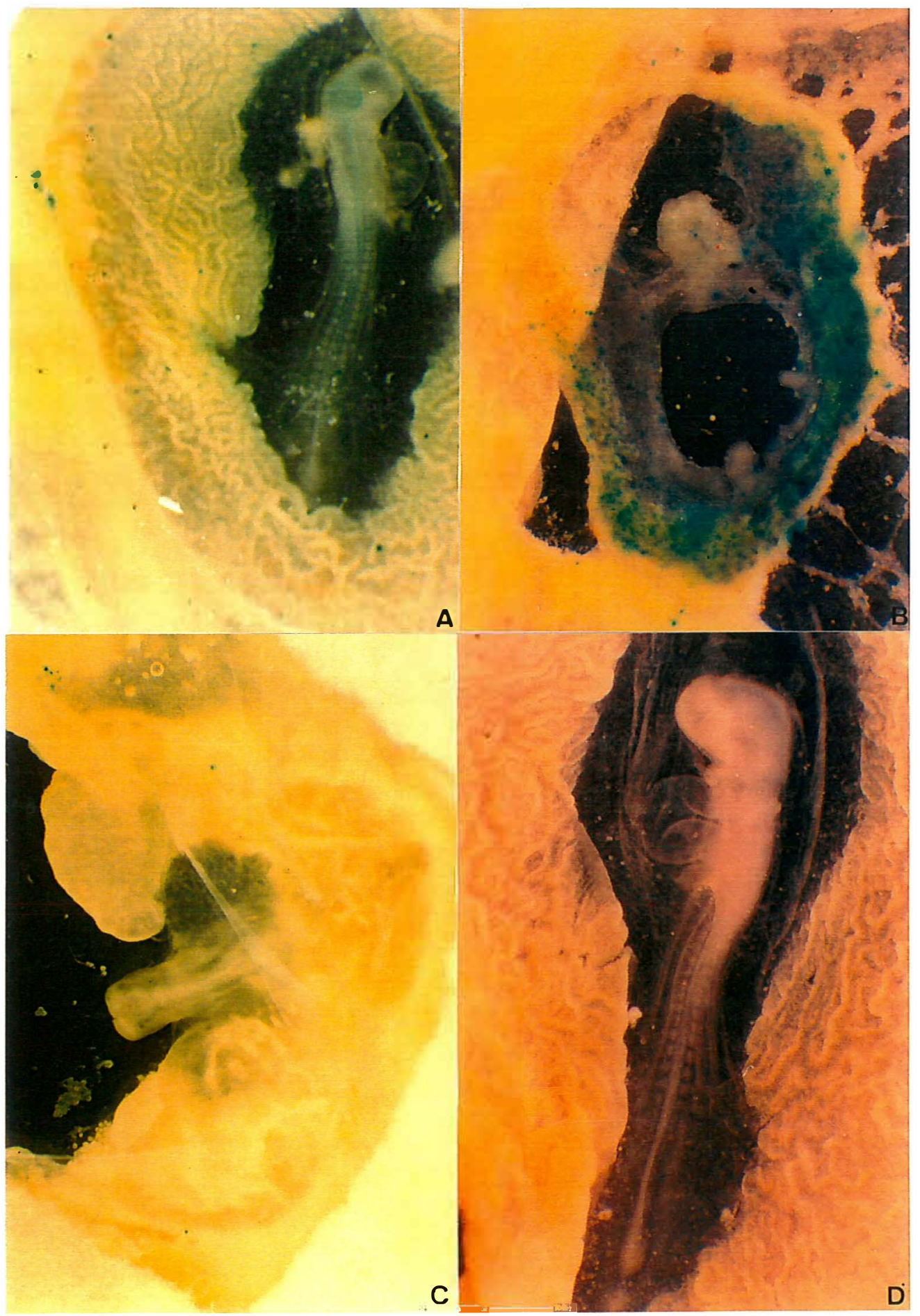

Figura 2. Embriões bombardeados com partículas de tungstênio de 0,2 $\mu \mathrm{m}$ (A) e 1,2 $\mathrm{m}$ (B e C) de diâmetro, utilizando-se 600 psi de hélio e $600 \mathrm{mmHg}$ de vácuo. Em (A e B), os embriões foram posicionados no centro do cone de dispersão das partículas, enquanto que em (C), o embrião foi posicionado a $1 \mathrm{~cm}$ de distância do centro do cone de dispersão das partículas. (D) representa um embrião não bombardeado (embrião controle). (A e C, 12X; B, 16X; D, 17X). 


\subsection{DISCUSSÃO}

A transferência de DNA em embriões de galinha in situ foi obtida com relativo sucesso. O promotor do CMV utilizado produziu forte expressão em muitas regiões do embrião, e o gene repórter lacZ foi facilmente detectado. Uma eficiência de transformação de $68,7 \%$ e uma taxa de sobrevivência de $31,2 \%$ foram obtidas com partículas de ouro, $600 \mathrm{mmHg}$ de vácuo e 600 psi de gás hélio. Todos os esforços para aumentar o nível de transformação, utilizando maiores pressões de gás hélio ou de vácuo, resultaram em maior expressão, mas, em contrapartida, a taxa de sobrevivência decresceu. O uso de partículas menores para reduzir os danos aos embriões resultou em menores taxas de eficiência de transformação.

Trabalhos previamente publicados, utilizando a técnica de biolística para a transferência de genes exógenos em embriões de galinha in ovo, foram conduzidos com sucesso ( $\mathrm{Li}$ et al., 1995; Muramatsu et al., 1997a). Li et al (1995) transformaram células germinativas primordiais, utilizando uma seringa cirúrgica adaptada e conseguiram detectar o gene exógeno em $20 \%$ dos frangos da prole G1. Muramatsu et al. (1997a) utilizaram partículas de tungstênio e 285 psi de nitrogênio, obtendo uma eficiência de transformação de $45,8 \%$ e uma taxa de sobrevivência de $42,9 \%$. Entretanto, o número e a intensidade de unidades de expressão foram baixos. Sob as nossas condições, maiores taxas de eficiência de transformação e nível de expressão foram obtidas. A alta pressão de gás hélio empregada em nossos experimentos, podem ter contado para a diferença observada entre os nossos resultados e os obtidos pelos outros trabalhos. 


\section{Cap. II TRANSFERÊNCIA DE GENES IN VITRO EM EMBRIÕES DE GALINHA POR MEIO DA BIOLÍSTICA (Biolistic Process for In Vitro Gene Transfer to Chicken Embryo)}

RIBEIRO L.A.; MARIANI, P.D.S.C., AZEVEDO, J.L.; RECH, E.L.; SCHMIDT, G.S.; COUTINHO, L.L. Biolistic Process for In Vitro Gene Transfer to Chicken Embryo. Poultry Science. (enviado para publicação), 1999. 


\section{TRANSFERÊNCIA DE GENES IN VITRO EM EMBRIÕES DE GALINHA POR MEIO DA BIOLÍSTICA (Biolistic Process for In Vitro Gene Transfer to Chicken Embryo)}

\section{RESUMO}

Embriões de galinha, cultivados em meio de cultura, foram bombardeados, utilizando-se um aparelho de biolística de alta pressão de gás hélio. $\mathrm{O}$ gene lacZ, sob o controle do promotor do citomegalovírus (CMV) humano, foi utilizado como gene repórter para a otimização dos fatores que afetam a eficiência de transformação. Os resultados mostraram uma relação inversa entre a taxa de sobrevivência e a eficiência de transformação. As melhores condições, associando sobrevivência dos embriões e eficiência de transformação, foram obtidas com 800 psi de gás hélio, $500 \mathrm{mmHg}$ de vácuo, partículas de ouro, distância de $8 \mathrm{~cm}$ percorrida pelo DNA-micropartículas até o embrião e posicionamento dos embriões a $0,5 \mathrm{~cm}$ de distância do centro do cone de dispersão das partículas. Com estas condições, a eficiência de transformação foi de $98,5 \%$; a taxa de sobrevivência, de $25,4 \%$; e o número de unidades de expressão nas células do corpo dos embriões variou de 100 a 1.000 pontos azuis. A expressão do gene que codifica para a proteina verde fluorescente ("green fluorescent protein"- GFP) também foi verificada em embriões bombardeados sob as condições ótimas de bombardeamento. Com os resultados obtidos, pode-se considerar a biolística como um método eficiente para a transformação de embriões de galinha, podendo ser utilizada como um sistema modelo para o estudo da expressão gênica e de promotores tecido-específicos. 


\section{SUMMARY}

Chicken embryos kept in culture medium were bombarded using a high helium gas pressure biolistic device. To optimize the factors that affect transformation efficiency, the lacZ gene under control of human cytomegalovirus (CMV) immediate early enhancer/promoter was used as a reporter gene. Results showed an inverse relationship between survival rate and transformation efficiency. The best conditions obtained associating embryo survival and transformation efficiency were achieved with 800 psi helium gas pressure, $500 \mathrm{mmHg}$ vacuum, gold particles, $8 \mathrm{~cm}$ DNA-coated microparticle flying distance to the embryo and embryo placement $0.5 \mathrm{~cm}$ from the center of the particle dispersion cone. Under these conditions, transformation efficiency was $98.5 \%$, survival rate $25.4 \%$ and the number of expression units in the embryo body cells varied between 100 and 1,000. Expression of green fluorescent protein (GFP) was also verified in embryos bombarded under optimal conditions. Based on the results obtained, biolistic can be considered an efficient method for transformation of chicken embryos and therefore can be used as a model system to study transient gene expression and tissue-specific promoters. 


\subsection{INTRODUÇÃO}

Várias técnicas têm sido utilizadas e desenvolvidas para a introdução de genes exógenos em células animais, visando tanto o estudo básico de função e regulação gênica, quanto a produção de animais transgênicos. Os métodos de infecção por retrovírus e microinjeção de pronúcleos de ovos recém-fertilizados são utilizados, quando integração e expressão gênica estáveis são desejadas, para a produção de animais transgênicos (Gordon, 1989). No entanto, quando expressão gênica transiente é desejada, outros métodos, tais como co-precipitação com fosfato de cálcio, lipofecção, eletroporação e biolística, podem ser utilizados para a transferência de DNA em uma variedade de espécies animais (Keown et al., 1990; Sanford et al., 1993; Demeneix et al., 1994; Muramatsu et al., 1997a).

Em galinhas, a técnica de infecção por retrovírus tem sido utilizada, com sucesso, para a introdução de genes exógenos na linhagem germinativa de embriões jovens (Salter et al., 1986; Bosselman et al., 1989). Da mesma forma, têm sido obtidas transferências de DNA para células da blastoderme (Petitte et al., 1990), células germinativas primordiais (Wentworth et al., 1989; Vick et al., 1993a) e células somáticas (Mima et al., 1995; Itoh et al., 1996). Microinjeção direta de DNA exógeno em ovos recém-fertilizados também tem sido desenvolvida. Entretanto, a integração do DNA na linhagem germinativa é um evento raro (Sang and Perry, 1989; Love et al., 1994). Outros métodos, tais como lipofecção in ovo (Demeneix et al., 1994), eletroporação (Muramatsu et al., 1997a) e biolística (Li et al., 1995; Muramatsu et al., 1997a; Ribeiro et al., 1999), têm sido utilizados em embriões de galinha e, somente, expressão transiente tem sido verificada.

A biolística é um método físico para a introdução de ácidos nucleicos e outras substâncias no interior de células ou tecidos intactos, através da utilização de micropartículas aceleradas a alta velocidade. Este método, desenvolvido por Sanford e colaboradores (Klein et al., 1987), tem sido amplamente aplicado e otimizado em várias espécies animais (ver revisões em Klein and Fitzpatrick-McElligott, 1993; Furth, 1997), devido à algumas vantagens como: bombardeamento simultâneo de muitas células, 
liberação de altas doses de DNA, possibilidade de co-transformação com dois ou mais plasmídeos e independência quanto ao uso de genótipos e protocolos específicos de cultura de tecidos (Yang et al., 1990; Klein et al., 1992; Sanford et al., 1993).

Para assegurar a eficiência de liberação de DNA dentro das células e diminuir os efeitos prejudiciais desta técnica, faz-se necessário otimizar os fatores físicos e biológicos, para que os resultados obtidos sejam repetitíveis e consistentes (Birch and Franks, 1991; Sanford et al., 1993). O presente trabalho descreve o desenvolvimento e a otimização da biolística, para a transferência de genes, in vitro, em embriões de galinha cultivados em meio de cultura.

\subsection{MATERIAIS E MÉTODOS}

\section{Embriōes de Galinha}

Ovos de galinha fertilizados da linhagem AgRoss foram incubados por 42 horas a $38^{\circ} \mathrm{C}$. Embriões possuindo de 13 a 16 somitos (estádio 11 ou 12 do desenvolvimento, Hamburger and Hamilton, 1951) foram retirados dos ovos, transferidos para uma placa de petri contendo meio de cultura $(0,36 \% \mathrm{NaCl}, 1 \%$ de bacto-ágar e $50 \%$ de clara fina do ovo), bombardeados e incubados novamente a $38^{\circ} \mathrm{C}$.

\section{Vetores de Expressão}

Dois plasmídeos foram utilizados para avaliar a expressão transiente de dois genes exógenos, o gene lacZ de Escherichia coli (pCMVß) e o GFP ("green fluorescent protein") da água-viva Aequorea victoria (pEGFP-N1). Ambos os genes estavam sob o controle do promotor humano citomegalovírus (CMV). O plasmídeo pCMVß foi utilizado para os experimentos de otimização das condições de bombardeamento. $\mathrm{O}$ protocolo de precipitação dos plasmídeos em partículas de ouro ou tungstênio, utilizando $\mathrm{CaCl}_{2}$ e espermidina, foi o descrito por Aragão et al. (1996). 


\section{Condições de Bombardeamento}

Um aparelho de alta pressão de gás hélio, baseado no modelo descrito por Sanford et al. (1991), foi utilizado para o bombardeamento dos embriões. A distância entre o disco de ruptura e a membrana carreadora foi de $0,6 \mathrm{~cm} \mathrm{e}$, da membrana carreadora até a tela de retenção, de $2 \mathrm{~cm}$. As distâncias da membrana carreadora até o embrião, correspondente à distância percorrida pelo DNA-micropartículas até o embrião, foram de 8,0 e $11,0 \mathrm{~cm}$.

Dois tipos de partículas foram testadas para a precipitação dos plasmídeos: ouro com diâmetro de 1,5 a 3,0 $\mu \mathrm{m}$ (Aldrich no. 32.658-5) e tungstênio com diâmetro de 1,2 $\mu \mathrm{m}$ (M10, Sylvania Inc.).

\section{Atividade da $\beta$-galactosidase e da GFP}

A atividade da $\beta$-galactosidase $(\beta$-gal) foi detectada por coloração histoquímica. Doze, dezoito e vinte e quatro horas após o bombardeamento, os embriões foram fixados em uma solução de paraformaldeído $4 \%$, por 5 minutos a $4^{\circ} \mathrm{C}$. Os embriões foram corados, durante 4 horas a $37^{\circ} \mathrm{C}$, com um substrato cromogênico contendo: $100 \mathrm{mM}$ de fosfato de sódio, $1,3 \mathrm{mM} \mathrm{MgCl}_{2}, 3 \mathrm{mM} \mathrm{K} \mathrm{Ke}_{4}(\mathrm{CN})_{6}, 3 \mathrm{mM}$ $\mathrm{K}_{3} \mathrm{Fe}(\mathrm{CN})_{6}$ e $\quad 1 \mathrm{mg} / \mathrm{ml} \quad \mathrm{X}$-gal (5-bromo-4-cloro-3-indolil- $\beta$-galactopiranoside). A detecção da expressão da $\beta$-gal foi realizada através de análise histoquímica, baseada na hidrólise do X-gal. Os produtos da hidrólise são convertidos a índigo insolúvel. A cor azul, gerada por essa hidrólise, facilita a localização da atividade da $\beta$-gal nos embriões transformados. Para a realização de cortes transversais de $6 \mu \mathrm{m}$ de espessura, os embriões foram emblocados na resina "LR White" e, a visualização ocorreu em microscópio óptico.

A atividade da GFP foi analisada 24 horas após o bombardeamento, não sendo necessário nenhum procedimento de fixação ou coloração. A detecção desta proteína foi realizada em embriões vivos, com o auxílio de um microscópio de fluorescência. A proteína fluorescente sintetizada possui excitação máxima a $488 \mathrm{~nm}$ e emissão máxima a $507 \mathrm{~nm}$. 
A transformação foi verificada através da ausência ou presença de pontos azuis (no caso da $\beta$-gal) ou pontos verdes fluorescentes (no caso da GFP), representando uma célula ou conjunto de células que estão expressando os genes (unidades de expressão). Os embriões que apresentaram atividade gênica foram classificados em duas categorias: 1) expressão nas células do corpo do embrião e/ou no tecido extraembrionário (expressão total), 2) expressão nas células do corpo do embrião.

Embriões, completamente degenerados no momento da fixação, foram descartados, pois não era possível determinar se expressavam $\beta$-gal. A taxa de sobrevivência e a porcentagem de embriões, expressando $\beta$-gal, foram calculadas, excluindo-se estes embriões do total da amostra. A taxa de sobrevivência foi determinada pelo número de embriões que possuíam o coração batendo no momento da fixação. Embriões não bombardeados foram utilizados como controles negativos e não apresentaram coloração ou fluorescência.

\section{Análises Estatisticas}

A significância das diferenças entre as porcentagens de embriões descartados, taxa de sobrevivência e eficiência de transformação foi examinada pelo teste do qui-quadrado (Luginbuke and Schlotzhauer, 1987).

\subsection{RESULTADOS}

Diferentes condições de bombardeamento foram testadas, visando aumentar o número de células transformadas, associado a um nível aceitável de danos aos tecidos bombardeados. Isto se faz necessário, pois, para cada espécie ou tipo de célula, diferentes condições de transferência de DNA são exigidas (Birch and Franks, 1991; Zelenin et al., 1991b; Williams et al., 1991; Klein et al., 1992).

Dentre os parâmetros que afetam a eficiência de transformação, podemos citar a velocidade com que as micropartículas atingem o alvo, a quantidade de células transformadas e os efeitos da onda de choque no tecido-alvo. Estes parâmetros são 
controlados por um grupo de fatores que interagem entre si, tais como: posicionamento do alvo em relação ao centro do cone de dispersão das partículas, tamanho das micropartículas, distância percorrida pelo DNA-micropartículas até o alvo, pressão do gás hélio e nível de vácuo dentro da câmara de bombardeamento (Sanford et al., 1993). Estes fatores foram avaliados, visando a obtenção das condições ótimas de bombardeamento, para a transferência transiente de genes em embriões de galinha in vitro.

\section{Posicionamento dos Embriōes em Relação ao Centro do Cone de Dispersão das Partículas}

Os experimentos foram iniciados com partículas de ouro, distância de 8 cm percorrida pelo DNA-micropartículas até o embrião, três pressões de gás hélio (900, 1200 e 1500 psi), vácuo parcial de $500 \mathrm{mmHg}$ e dois posicionamentos dos embriões em relação ao centro do cone de dispersão das partículas ( 1 e $2 \mathrm{~cm}$ ). Os embriões não foram posicionados no centro, pois segundo Russel et al. (1992), nesta área, as células sofrem sérios danos, tornando-se incapazes de posterior divisão ou crescimento.

Os resultados, na Tabela 1 , mostraram que todos os embriões posicionados a $1 \mathrm{~cm}$ de distância apresentaram atividade enzimática, sendo que a pressão de 900 psi foi a que mostrou maior índice de embriões expressando $\beta$-gal nas células do corpo (88,9\%). Por outro lado, em embriões posicionados a $2 \mathrm{~cm}$ de distância, a pressão de 1500 psi foi a que apresentou melhor eficiência de transformação (100\%), enquanto que $62,5 \%$ dos embriões bombardeados com 1200 psi apresentaram expressão da $\beta$-gal. 
Tabela 1. Efeito da pressão de hélio na expressão da $\beta$-gal em embriões posicionados a 1 e $2 \mathrm{~cm}$ do centro do cone de dispersão das partículas, utilizando partículas de ouro e $500 \mathrm{~mm} \mathrm{Hg}$ de vácuo.

\begin{tabular}{|c|c|c|c|c|c|c|c|c|}
\hline \multirow[b]{2}{*}{$\begin{array}{l}\text { Pressão de } \\
\text { Hélio (psi) }\end{array}$} & \multicolumn{4}{|c|}{$1 \mathrm{~cm}$} & \multicolumn{4}{|c|}{$2 \mathrm{~cm}$} \\
\hline & $\mathrm{n}$ & $\begin{array}{l}\% \text { embriões } \\
\text { com } \\
\text { expressão } \\
\text { total }^{1}\end{array}$ & $\begin{array}{l}\text { \% embriões } \\
\text { com } \\
\text { expressão nas } \\
\text { células do } \\
\text { corpo }\end{array}$ & $\begin{array}{l}\mathrm{N}^{0} \text { de u.e } \\
\text { nas } \\
\text { células do } \\
\text { corpo do } \\
\text { embrião }\end{array}$ & $\mathrm{n}$ & $\begin{array}{l}\% \text { embriões } \\
\text { com } \\
\text { expressão } \\
\text { total }^{1}\end{array}$ & $\begin{array}{l}\text { \% embriões } \\
\text { com } \\
\text { expressão nas } \\
\text { células do } \\
\text { corpo }\end{array}$ & $\begin{array}{l}\mathrm{N}^{\circ} \text { de u.e } \\
\text { nas } \\
\text { células do } \\
\text { corpo do } \\
\text { embrião }\end{array}$ \\
\hline 900 & 9 & 100 & 88,9 & 44 & - & ---- & -.- & --- \\
\hline 1200 & 9 & 100 & 66,7 & 45 & 8 & 62,5 & 12,5 & 3 \\
\hline 1500 & 9 & 100 & 77.8 & 59 & 6 & 100 & 50,0 & 9 \\
\hline
\end{tabular}

u. e = unidades de expressão

${ }^{1}$ Embriões com expressão da $\beta$-gal nas cél ul asdo corpo e/ou no t ecido ext ra-embrionário.

A distância percorrida pelo DNA-micropartículas atéo embrião foi de $8 \mathrm{~cm}$.

Embora tenha sido observado melhor eficiência de transformação e maior número de células transformadas nos embriões posicionados a $1 \mathrm{~cm}$ de distância do centro do cone de dispersão das partículas, estes sofreram sérios danos no desenvolvimento dos tecidos (Figura 1A, B). Por outro lado, embriões posicionados a 2 cm de distância do centro do cone de dispersão das partículas apresentaram desenvolvimento normal dos tecidos mas, um menor número de células transformadas (Figure 1C). Estes resultados mostraram uma relação inversa entre número de células transformadas e danos no desenvolvimento dos embriões, ou seja, quanto maior o número de células transformadas, maiores foram os danos sofridos pelos embriões. $\mathrm{O}$ mesmo foi observado por Russel et al. (1992) e Gendreau et al. (1995). Outra observação importante foi o reduzido número de células transformadas em embriões posicionados a $2 \mathrm{~cm}$ de distância do centro do cone de dispersão das partículas. A causa provável pode ter sido a dispersão heterogênea das micropartículas, visto que somente um pequeno número de partículas atingiu os embriões mais distantes. 

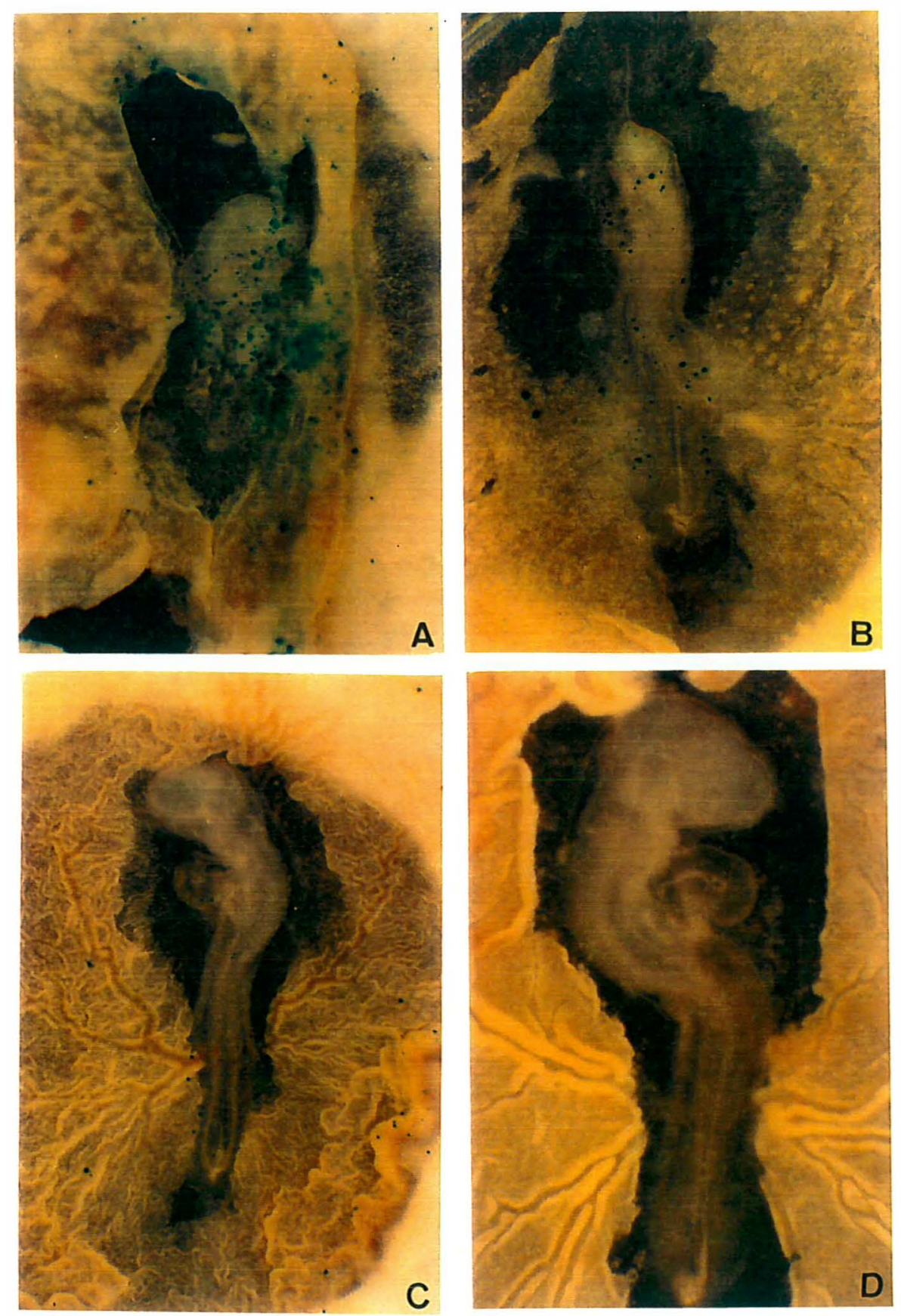

Figura 1. Embriões bombardeados com partículas de ouro, $500 \mathrm{mmHg}$ de vácuo e posicionados a $1 \mathrm{~cm}$ (A e B) ou $2 \mathrm{~cm}(\mathrm{C})$ do centro do cone de dispersão das partículas. Em A e C, os embriões foram bombardeados com 1500 psi de hélio, enquanto que, em B, os embriões foram bombardeados com 900 psi. D) Embrião não bombardeado (controle negativo). Os pontos azuis indicam expressão da $\beta$-gal. A distância percorrida pelo DNA-micropartículas até o embrião foi de $8 \mathrm{~cm}$. (A, B e D, $12 \mathrm{X}$; C, 9X). 


\section{Microparticulas de Tungstênio}

Com o objetivo de reduzir os danos ocorridos no desenvolvimento dos tecidos dos embriões bombardeados, partículas de tungstênio de menor diâmetro (1,2 $\mu \mathrm{m})$ do que o ouro, foram testadas. Doze embriões bombardeados com 900 psi de gás hélio, $500 \mathrm{mmHg}$ de vácuo e posicionados a $1 \mathrm{~cm}$ de distância do centro de dispersão das partículas, foram analisados quanto à expressão da $\beta$-gal. Os resultados mostraram que $75 \%$ dos embriões bombardeados foram transformados e que todos apresentaram expressão da $\beta$-gal nas células do corpo. $O$ número de unidades de expressão variou de 5 a 20, no corpo do embrião e de 20 a 50, no tecido extra-embrionário. A maioria dos embriões apresentava batimento cardíaco 24 horas após o bombardeamento, assim como, um pequeno atraso no desenvolvimento dos tecidos (Figura 2).

\section{Distância percorrida pelo DNA-micropartículas até o embrião}

Visando aumentar o número de unidades de expressão no corpo do embrião, a distância percorrida pelo DNA/micropartículas foi aumentada de 8 para 11 $\mathrm{cm}$, visto que quanto maior a distância percorrida pelas micropartículas, maior é a área de dispersão destas ao atingirem o alvo (Sanford et al., 1993).

As pressões de 900 e 1200 psi de gás hélio e vácuo parcial de 500 mmHg foram utilizadas para avaliar a expressão da $\beta$-gal nos embriões bombardeados a 1 e 2 cm de distância do centro do cone de dispersão das partículas (Tabela 2). Os resultados mostraram que somente a pressão de 1200 psi apresentou expressão da $\beta$-gal nas células do corpo dos embriões. A pressão de 900 psi mostrou-se bastante ineficiente para a transformação de embriões posicionados a $2 \mathrm{~cm}$ de distância, pois nenhum embrião expressou atividade da $\beta$-gal. A maioria dos embriões, independente das condições utilizadas, apresentou desenvolvimento normal dos tecidos e batimento cardíaco no momento da fixação (24 horas após o bombardeamento). O número de unidades de expressão variou de 4 a 30, no corpo do embrião e de 10 a 40, no tecido extraembrionário (Figura 3). 


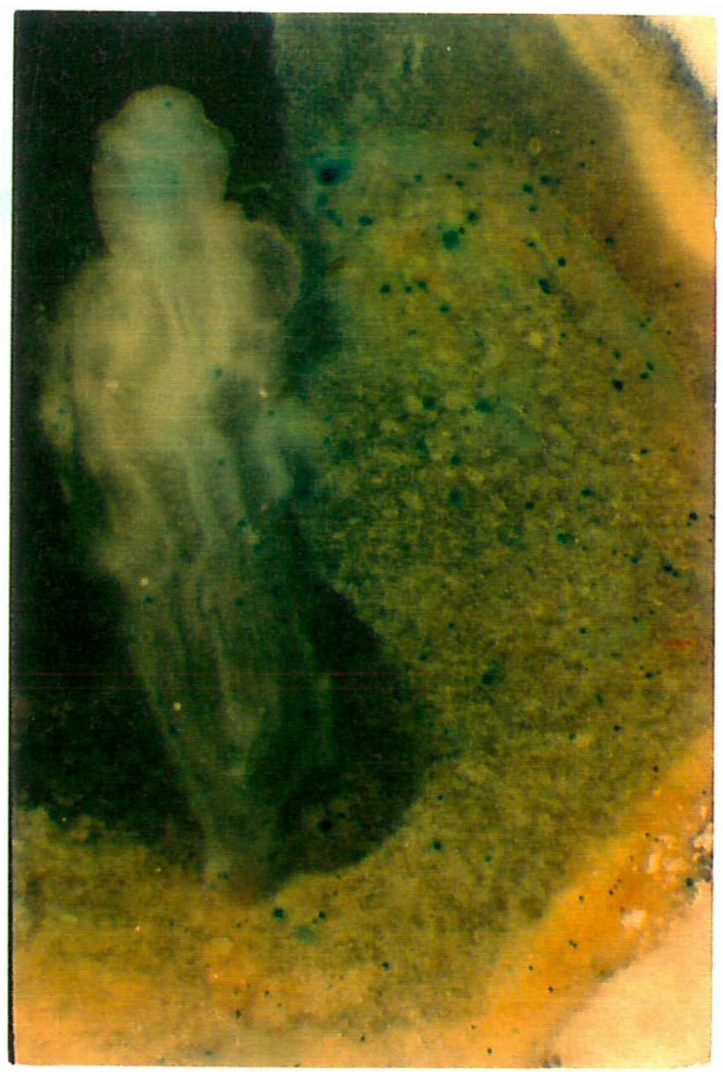

Figura 2. Embrião posicionado a $1 \mathrm{~cm}$ do centro do cone de dispersão das partículas e bombardeado com partículas de tungstênio de 1,2 $\mu \mathrm{m}, 900$ psi de hélio e 500 mmHg de vácuo (17X). A distância percorrida pelo DNA-micropartículas até o embrião foi de $8 \mathrm{~cm}$ 

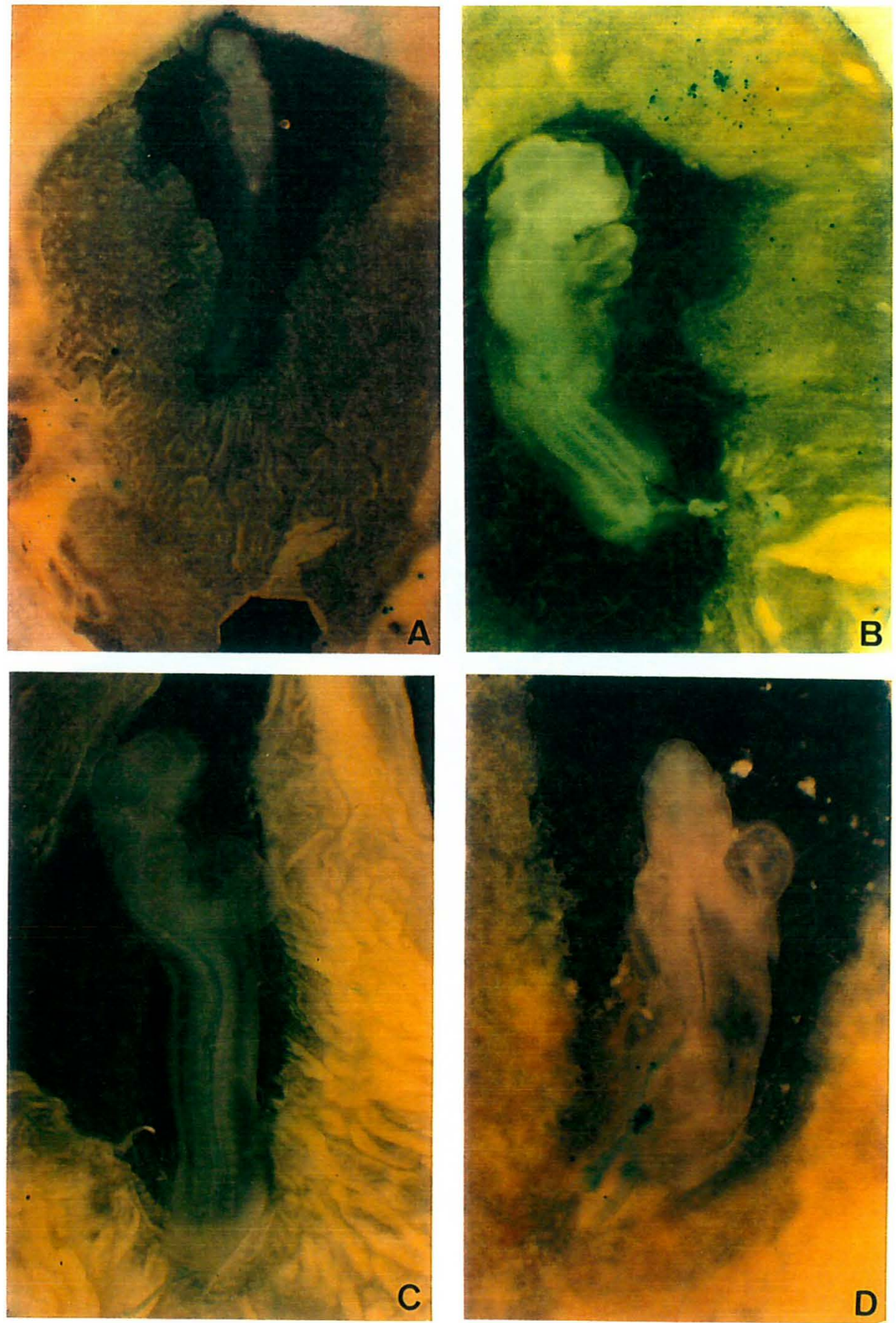

Figura 3. Embriões bombardeados com partículas de tungstênio de 1,2 $\mu \mathrm{m}$ e vácuo de $500 \mathrm{mmHg}$ e posicionados a $1 \mathrm{~cm}$ (A e B) ou $2 \mathrm{~cm}$ (C e D) do centro do cone de dispersão das partículas. Em A e $\mathrm{C}$, os embriões foram bombardeados com 900 psi de hélio enquanto que, em B e D, os embriões foram bombardeados com 1200 psi. A distância percorrida pelo DNA-micropartículas até o embrião foi de $11 \mathrm{~cm}$. (A, 6X; B e C, 12X; D, 18X). 
Tabela 2. Efeito da pressão de hélio na expressão da $\beta$-gal em embriões posicionados a 1 e $2 \mathrm{~cm}$ do centro do cone de dispersão das partículas, utilizando partículas de tungstênio M10 e vácuo de $500 \mathrm{mmHg}$.

\begin{tabular}{|c|c|c|c|c|c|c|c|c|}
\hline \multirow[b]{2}{*}{$\begin{array}{l}\text { Pressão de } \\
\text { Hélio (psi) }\end{array}$} & \multicolumn{4}{|c|}{$1 \mathrm{~cm}$} & \multicolumn{4}{|c|}{$2 \mathrm{~cm}$} \\
\hline & $\mathrm{n}$ & $\begin{array}{l}\text { \% embriões } \\
\text { com } \\
\text { expressão } \\
\text { total }^{1}\end{array}$ & $\begin{array}{l}\text { \% embriões } \\
\text { com } \\
\text { expressão nas } \\
\text { células do } \\
\text { corpo }\end{array}$ & $\begin{array}{l}\mathrm{N}^{0} \text { de u. } \mathrm{e}^{*} \\
\text { nas células } \\
\text { do corpo } \\
\text { do embrião }\end{array}$ & $\mathrm{n}$ & $\begin{array}{l}\text { \% embriões } \\
\text { com } \\
\text { expressão } \\
\text { total }^{1}\end{array}$ & $\begin{array}{l}\text { \% embriões } \\
\text { com } \\
\text { expressão nas } \\
\text { células do } \\
\text { corpo }\end{array}$ & $\begin{array}{l}\mathrm{N}^{0} \text { de u.e } \\
\text { nas células } \\
\text { do corpo do } \\
\text { embrião }\end{array}$ \\
\hline 900 & 6 & 50,0 & 0,0 & 0 & 4 & 0,0 & 0,0 & 0 \\
\hline 1200 & 22 & 72,7 & 27,3 & 17 & 20 & 35,0 & 30,0 & 9 \\
\hline
\end{tabular}

* u.e. $=$ unidades de expressão

' Embriões com expressão da $\beta$-gal nas células do corpo e/ou no tecido extra-embrionário. A distância percorrida pelo DNA-micropartículas até o embrião foi de $11 \mathrm{~cm}$

Com este experimento, os danos aos embriões foram minimizados, mas a eficiência de transformação e o número de células transformadas foram reduzidas.

\section{Embriões Posicionados a $0,5 \mathrm{~cm}$ do Centro do Cone de Dispersão das Partículas}

Visto que partículas de menor diâmetro e maior distância percorrida pelo DNA-micropartículas $(11 \mathrm{~cm})$ reduziram os danos aos embriões bombardeados, uma nova série de experimentos foi realizada para avaliar a eficiência de transformação e a sobrevivência dos embriões posicionados a $0,5 \mathrm{~cm}$ de distância do centro do cone de dispersão das partículas. As condições de bombardeamento utilizadas foram: pressões de gás hélio de 600 e 900 psi e vácuo parcial de $500 \mathrm{mmHg}$. Os resultados mostraram que a eficiência de transformação foi baixa para as duas pressões testadas (37,5\% com 600 psi e 45,4\% com 900 psi). O número de unidades de expressão também foi bastante pequeno, tanto nas células do corpo dos embriões, quanto no tecido extra-embrionário (menos de 10 pontos azuis). A maioria dos embriões, no entanto, apresentou desenvolvimento normal dos tecidos e batimento cardíaco no momento da fixação (24 horas após o bombardeamento).

$\mathrm{O}$ pequeno número de unidades de expressão e a baixa eficiência de transformação obtidos neste experimento, podem estar associados à desaceleração das 
partículas, em virtude da distância percorrida de $11 \mathrm{~cm}$. Não foram realizados testes aumentando a pressão de gás hélio, pois quanto maior a pressão empregada, maiores são os danos causados ao embrião (Russel et al., 1992; Sanford et al., 1993). Desta forma, optou-se por diminuir a distância percorrida pelo DNA-micropartículas até o embrião para, novamente, $8 \mathrm{~cm}$. Outra modificação realizada foi a utilização de partículas de ouro, em substituição ao tungstênio. O material das partículas foi mudado, pois o ouro apresentou melhores resultados em experimentos anteriores, e também tem sido o mais utilizado pela literatura em células animais (Johnston et al., 1991; Rech et al., 1996).

Utilizando-se partículas de ouro, 11 embriões foram bombardeados com 900 psi de gás hélio, $500 \mathrm{mmHg}$ de vácuo e posicionados a $0,5 \mathrm{~cm}$ de distância do centro do cone de dispersão das partículas e a $8 \mathrm{~cm}$ da membrana carreadora. Os resultados mostraram que todos os embriões bombardeados apresentaram atividade enzimática, tanto nas células do corpo, quanto no tecido extra-embrionário, representando $100 \%$ de eficiência de transformação. O número de unidades de expressão variou de 20 a 200 , no corpo do embrião e de 150 a 300, no tecido extra-embrionário, mostrando um padrão de dispersão bastante homogêneo. No momento da fixação (18 horas após o bombardeamento), nenhum dano sério aos tecidos foi verificado, entretanto, os embriões não apresentavam batimentos cardíacos e um pequeno atraso no desenvolvimento dos tecidos foi detectado (Figura 4).

Com base nestes resultados, pode-se concluir que as condições empregadas neste experimento, quando comparadas com as demais testadas, apresentaram os melhores resultados, quanto a eficiência de transformação, número de células transformadas e distribuição homogênea das unidades de expressão por todo o embrião e tecido extra-embrionário. Entretanto, os embriões apresentavam ainda um atraso no desenvolvimento dos tecidos e baixa taxa de sobrevivência. 


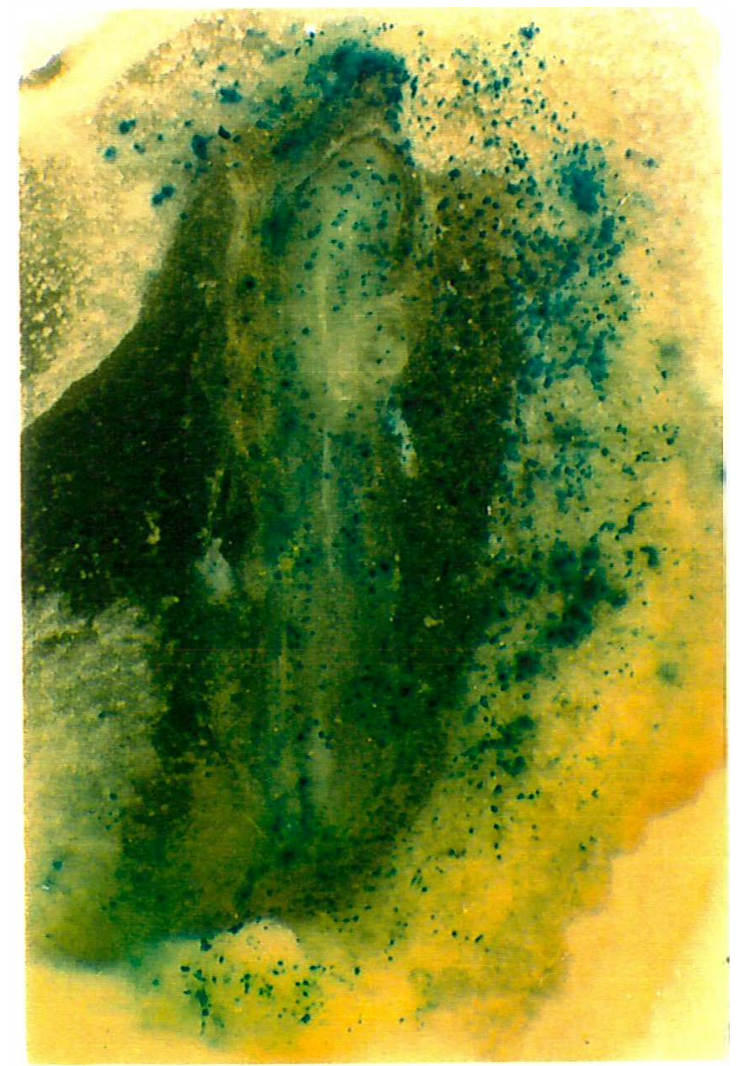

Figura 4. Embrião posicionado a $0,5 \mathrm{~cm}$ do centro do cone de dispersão das partículas e bombardeado com partículas de ouro, 900 psi de hélio e $500 \mathrm{mmHg}$ de vácuo (12X). A distância percorrida pelo DNA-micropartículas até o embrião foi de $8 \mathrm{~cm}$. 


\section{Pressões de Gás Hélio}

Com o objetivo de reduzir os danos causados aos embriões, menores pressões de gás hélio foram testadas, mantendo-se as outras variáveis não alteradas. Cinquenta e dois embriões foram bombardeados com 600, 700 e 800 psi de gás hélio, vácuo de $500 \mathrm{mmHg}$, partículas de ouro e posicionados a $0,5 \mathrm{~cm}$ do centro do cone de dispersão das partículas e a $8 \mathrm{~cm}$ da membrana carreadora. No momento da fixação (12 horas após o bombardeamento), a quantidade de embriões descartados variou de 18,7\% a $44,4 \%$ e a taxa de sobrevivência, de 33,3\% a 60,0\% (Tabela 3). No entanto, estas diferenças não foram estatisticamente significativa entre as três pressões empregadas, tanto para a quantidade de embriões descartados, quanto para as taxas de sobrevivência $\left(\chi^{2}=2,545^{\text {n.s. }}\right.$ e $1,783^{\text {n.s. }}$, respectivamente, G.L. $\left.=2\right)$.

Tabela 3. Efeito da pressão de hélio na porcentagem de embriões descartados, na taxa de sobrevivência e na expressão da $\beta$-gal em embriões posicionados a $0,5 \mathrm{~cm}$ do centro do cone de dispersão das partículas, utilizando partículas de ouro e vácuo de $500 \mathrm{mmHg}$.

\begin{tabular}{|c|c|c|c|c|c|}
\hline \multirow{2}{*}{$\begin{array}{l}\text { Pressão } \\
\text { de Hélio } \\
\text { (psi) }\end{array}$} & \multirow[b]{2}{*}{$\mathrm{n}$} & \multirow[b]{2}{*}{$\begin{array}{l}\text { \% embriões } \\
\text { descartados }\end{array}$} & \multirow[b]{2}{*}{$\begin{array}{l}\text { Taxa de } \\
\text { Sobrevivência } \\
(\%)\end{array}$} & \multicolumn{2}{|c|}{ Eficiência de Transformação } \\
\hline & & & & $\begin{array}{l}\% \text { embriões com } \\
\text { expressão total }{ }^{3}\end{array}$ & $\begin{array}{l}\text { \% embriões com } \\
\text { expressão nas } \\
\text { células do corpo }\end{array}$ \\
\hline 600 & 16 & $18,7(3 / 16)^{1}$ & $53,8(7 / 13)^{2}$ & $100(13 / 13)^{4}$ & $100,0(13 / 13)^{5}$ \\
\hline 700 & 18 & $44,4(8 / 18)$ & $60,0(6 / 10)$ & $100(10 / 10)$ & $90,0(9 / 10)$ \\
\hline 800 & 18 & $33,3(6 / 18)$ & $33,3(4 / 12)$ & $100(12 / 12)$ & $91,7(11 / 12)$ \\
\hline
\end{tabular}

${ }^{t}$ No. de embriões degenerados 12 horas após o bombardeamento /No. total de embriões bombardeados.

${ }^{2}$ No. de embriões com batimento cardíaco 12 horas após o bombardeamento/No. de embriões bombardeados, excluindo os descartados.

${ }^{3}$ Embriões com expressão da $\beta$-gal nas células do corpo e/ou no tecido extra-embrionário.

${ }^{4}$ No. de embriões expressando $\beta$-gal/No. de embriões bombardeados, excluindo os descartados.

${ }^{5}$ No. de embriões expressando $\beta$-gal nas células do corpo/No. de embriões bombardeados, excluindo os descartados.

A distância percorrida pelo DNA-micropartículas até o embrião foi de $8 \mathrm{~cm}$.

Quanto à expressão da $\beta$-gal, os resultados mostraram que todas as pressões utilizadas apresentaram 100\% de transformação e que somente a pressão de 600 psi mostrou $100 \%$ de embriões expressando $\beta$-gal nas células do corpo. Entretanto, 
estatisticamente não houve diferença entre as três pressões empregadas $\left(\chi^{2}=1,282^{\text {n.s. }}\right.$, G.L.=2). No entanto, quando observou-se o número de unidades de expressão nas células do corpo, somente a pressão de 800 psi apresentou mais de 1.000 pontos azuis (Tabela 4). A Figura 5 mostra uma comparação da eficiência de transformação entre as pressões testadas, evidenciando a quantidade de unidades de expressão em cada embrião e a morfologia destes.

Tabela 4. Efeito da pressão de hélio no número de unidades de expressão nas células do corpo de embriões posicionados a $0,5 \mathrm{~cm}$ do centro do cone de dispersão das partículas, utilizando partículas de ouro e $500 \mathrm{mmHg}$ de vácuo.

\begin{tabular}{|c|c|c|c|c|}
\hline \multirow{2}{*}{$\begin{array}{l}\text { Pressão de Hélio } \\
\text { (psi) }\end{array}$} & \multirow[b]{2}{*}{$n^{1}$} & \multicolumn{3}{|c|}{ \% Embriões com expressão nas células do corpo } \\
\hline & & 10 a 100 u.e. & 100 a 1.000 u.e. & Mais de 1.000 u.e. \\
\hline 600 & 13 & $53,8(7 / 13)$ & $46,2(6 / 13)$ & --- \\
\hline 700 & 10 & $70,0(7 / 10)$ & $20,0(2 / 10)$ & $-\cdots$ \\
\hline 800 & 12 & $16,7(2 / 12)$ & $41,7(5 / 12)$ & $33,3(4 / 12)$ \\
\hline
\end{tabular}

${ }^{1}$ No. de embriões bombardeados, excluindo os descartados.

*u.e. $=$ unidades de expressão.

A distância percorrida pelo DNA-micropartículas até o embrião foi de $8 \mathrm{~cm}$

Com base nestes resultados, pode-se determinar como ótima para este experimento, a pressão de 800 psi. Entretanto, no momento da fixação, foi observado que a maioria dos embriões bombardeados nesta pressão, apesar de não terem sofrido nenhum dano sério aos tecidos, possuíam um atraso no desenvolvimento dos tecidos.

\section{Níveis de Vácuo}

Com o objetivo de diminuir o atraso no desenvolvimento dos embriões, diferentes níveis de vácuo foram testados com a pressão de 800 psi. Foram avaliados três níveis de vácuo: 400, 500 e $600 \mathrm{mmHg}$.

Os resultados mostraram que o vácuo de $400 \mathrm{mmHg}$ apresentou menor quantidade de embriões descartados e maior taxa de sobrevivência (Tabela 5). Isto já era esperado, pois, quanto menor o nível de vácuo, maior é a resistência do ar e, portanto, menor é a velocidade com que as partículas atingem o embrião. Consequentemente, os 

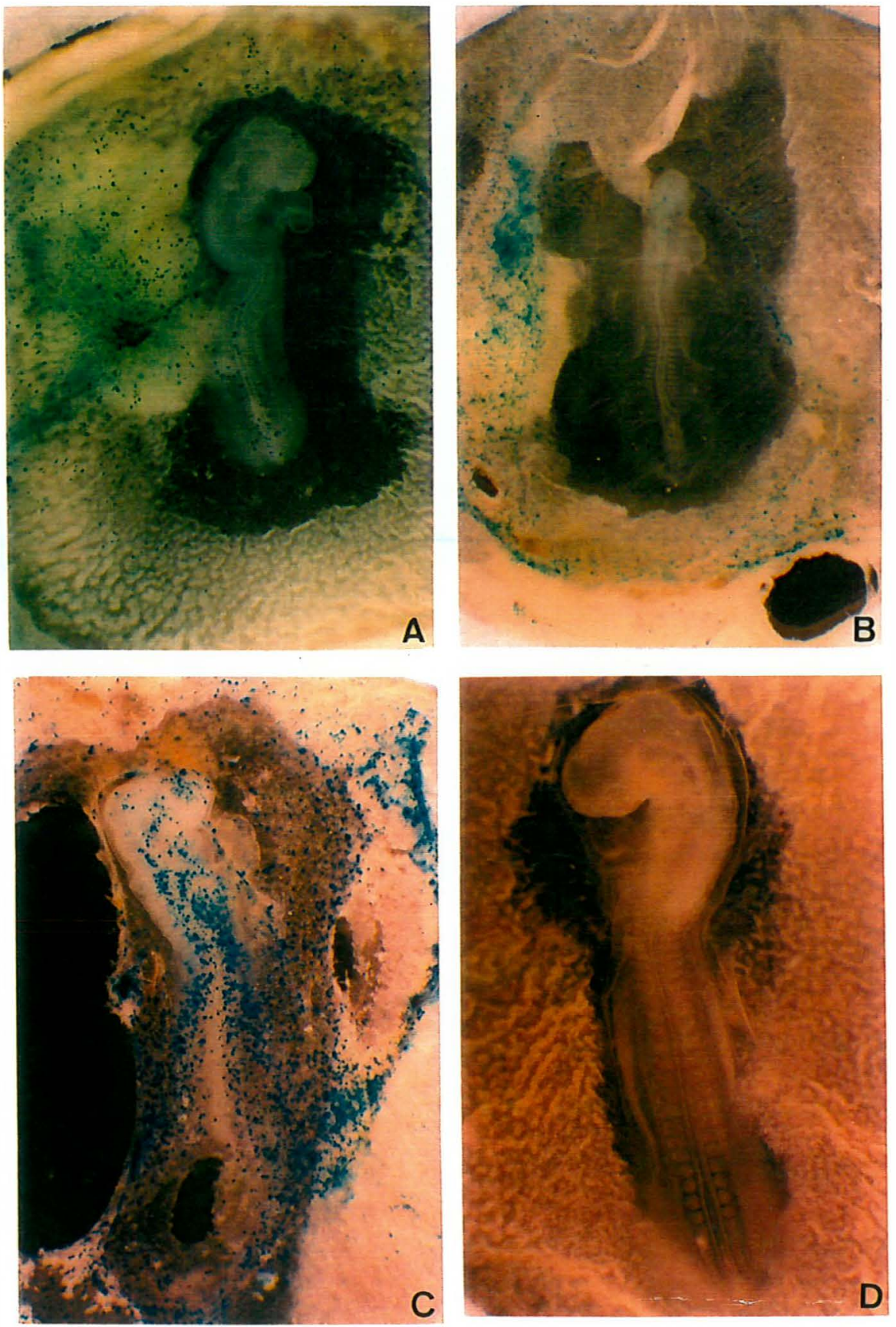

Figura 5. Embriões posicionados a $0,5 \mathrm{~cm}$ do centro do cone de dispersão das partículas e bombardeados com partículas de ouro, $500 \mathrm{mmHg}$ de vácuo e $600 \mathrm{psi}$ (A) ou 700 psii (B) ou 800 psi (C) de hélio. D) Embrião controle (não bombardeado).A distância percorrida pelo DNA-micropartículas até o embrião foi de $8 \mathrm{~cm}$. (A, 9X; B, 8X; C, 13X; D, 15X). 
efeitos da onda de choque, provocados pela pressão de hélio, são minimizados, causando menos danos aos embriões. Estatisticamente, no entanto, não houve diferença significativa entre os níveis de vácuo empregados no número de embriões descartados $\left(\chi^{2}=3,181^{\text {n.s. }}, G . L .=2\right)$, na taxa de sobrevivência $\left(\chi^{2}=4,031^{\text {n.s. }}, G . L .=2\right)$ e na expressão da $\beta$-gal $\left(\chi^{2}=2,726^{\text {n.s. }}, G . L .=2\right)$. Somente quando observa-se o número de unidades de expressão nas células do corpo, é que pode-se distinguir o efeito do vácuo na expressão da $\beta$-gal. Dos três níveis de vácuo testados, somente o de $400 \mathrm{mmHg}$ não apresentou nenhum embrião com mais de 1.000 unidades de expressão nas células do corpo (Tabela 6). A diferença entre 500 e $600 \mathrm{mmHg}$ de vácuo foi verificada em função dos danos provocados aos tecidos dos embriões. Embriões bombardeados com $600 \mathrm{mmHg}$ apresentaram maiores danos aos tecidos no momento da fixação (24 horas após o bombardeamento). Por outro lado, embriões bombardeados com $500 \mathrm{mmHg}$ apresentaram um pequeno atraso no desenvolvimento, mas nenhum dano sério nos tecidos (Figura 6).

Tabela 5. Efeito do nível de vácuo na quantidade de embriões descartados, na taxa de sobrevivência e na expressão da $\beta$-gal, em embriões bombardeados com partículas de ouro, 800 psi de hélio e posicionados a $0,5 \mathrm{~cm}$ centro do cone de dispersão das partículas.

\begin{tabular}{|c|c|c|c|c|c|}
\hline \multirow{2}{*}{$\begin{array}{l}\text { Nível de } \\
\text { Vácuo } \\
(\mathrm{mmHg})\end{array}$} & \multirow[b]{2}{*}{$\mathrm{n}$} & \multirow[b]{2}{*}{$\begin{array}{l}\text { \% embriões } \\
\text { descartados }\end{array}$} & \multirow{2}{*}{$\begin{array}{l}\text { Taxa de } \\
\text { Sobrevivência } \\
(\%)\end{array}$} & \multicolumn{2}{|c|}{ Eficiência de Transformação } \\
\hline & & & & $\begin{array}{l}\text { \% embriões com } \\
\text { expressão total }\end{array}$ & $\begin{array}{l}\text { \% embriões com } \\
\text { expressão nas } \\
\text { células do corpo }\end{array}$ \\
\hline 400 & 18 & $11,1(2 / 18)^{1}$ & $62,5(10 / 16)^{2}$ & $100(16 / 16)^{4}$ & $100(16 / 16)^{5}$ \\
\hline 500 & 18 & $33,3(6 / 18)$ & $33,3(4 / 12)$ & $100(12 / 12)$ & $91,7(11 / 12)$ \\
\hline 600 & 24 & $33,3(8 / 24)$ & $31,3(5 / 16)$ & $100(16 / 16)$ & $100(16 / 16)$ \\
\hline \multicolumn{6}{|c|}{$\begin{array}{l}{ }^{3} \text { Embriões com expressão da } \beta \text {-gal nas células do corpo e/ou no tecido extra-embrionário. } \\
{ }^{4} \text { No. de embriões expressando } \beta \text {-gal/No. de embriões bombardeados, excluindo os descartados. } \\
{ }^{5} \text { No. de embriões expressando } \beta \text {-gal nas células do corpo/No. de embriões bombardeados, excluindo os } \\
\text { descartados. }\end{array}$} \\
\hline
\end{tabular}



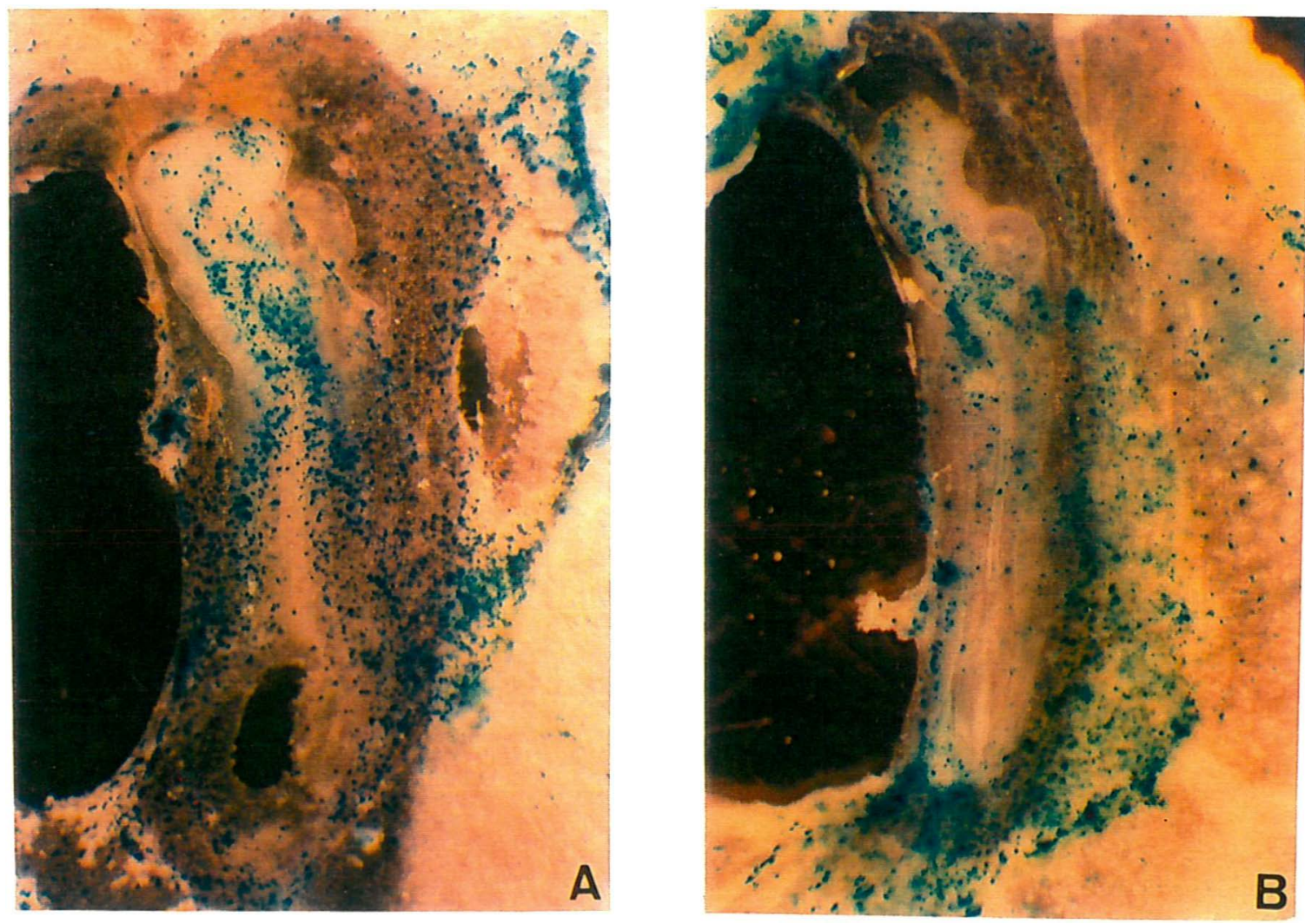

Figura 6. Embriões posicionados a $0,5 \mathrm{~cm}$ do centro do cone de dispersão das partículas e bombardeados com partículas de ouro, 800 psi de hélio e $500 \mathrm{mmHg}$ (A) ou 600 mmHg (B) de vácuo. A distância percorrida pelo DNA-micropartículas até o embrião foi de $8 \mathrm{~cm}$. (A, 13X; B, 14X). 
Tabela 6. Efeito do nível de vácuo na quantidade de unidades de expressão nas células do corpo de embriões bombardeados com partículas de ouro, 800 psi de hélio e posicionados a $0,5 \mathrm{~cm}$ centro do cone de dispersão das partículas.

\begin{tabular}{ccccc}
\hline \multirow{2}{*}{$\begin{array}{c}\text { Nível de Vácuo } \\
(\mathrm{mmHg})\end{array}$} & $\mathrm{n}^{1}$ & \multicolumn{3}{c}{ \% Embriões com expressão nas células do corpo } \\
\cline { 3 - 5 } 10 100 u.e. & 100 a 1.000 u.e. & Mais de 1.000 u.e. \\
\hline 400 & 16 & $62,5(10 / 16)$ & $37,5(6 / 16)$ & --- \\
500 & 12 & $16,7(2 / 12)$ & $41,7(5 / 12)$ & $33,3(4 / 12)$ \\
600 & 16 & $31,3(5 / 16)$ & $43,7(7 / 16)$ & $25,0(4 / 16)$ \\
\hline
\end{tabular}

${ }^{1}$ No. de embriões bombardeados, excluindo os descartados.

* u.e. $=$ unidades de expressão

\section{Tempo de Incubação em Meio de Cultura}

Para verificar se o tempo de incubação, que os embriões permaneciam em meio de cultura após o bombardeamento, estava diminuindo a viabilidade destes, uma nova série de experimentos foi conduzida. Foram avaliadas as taxas de sobrevivência 12 e 24 horas após o bombardeamento. A quantidade de embriões descartados e a expressão da $\beta$-gal nos embriões, também, foram verificadas.

Os resultados representados na Tabela 7 , demonstraram que as taxas de sobrevivência obtidas ( $29,6 \%$ com 12 horas e $40,0 \%$ com 24 horas) não diferiram entre si estatisticamente $\left(\chi^{2}=0,617^{\text {n.s. }}, G . L .=1\right)$, significando que a sobrevivência dos embriões não foi afetada pelo tempo de incubação em meio de cultura. A quantidade de embriões descartados e a expressão da $\beta$-gal nas células do corpo dos embriões, também, não foram estatisticamente diferentes $\left(\chi^{2}=1,146^{\text {n.s. }}\right.$ e $1,416^{\text {n.s }}$, G.L. $\left.=1\right)$. Os embriões, independente do tempo de permanência no meio de cultura, apresentaram um atraso no desenvolvimento dos tecidos (Figura 7).

Com base nestes resultados, os próximos experimentos foram realizados incubando os embriões por 24 horas em meio de cultura após o bombardeamento. 

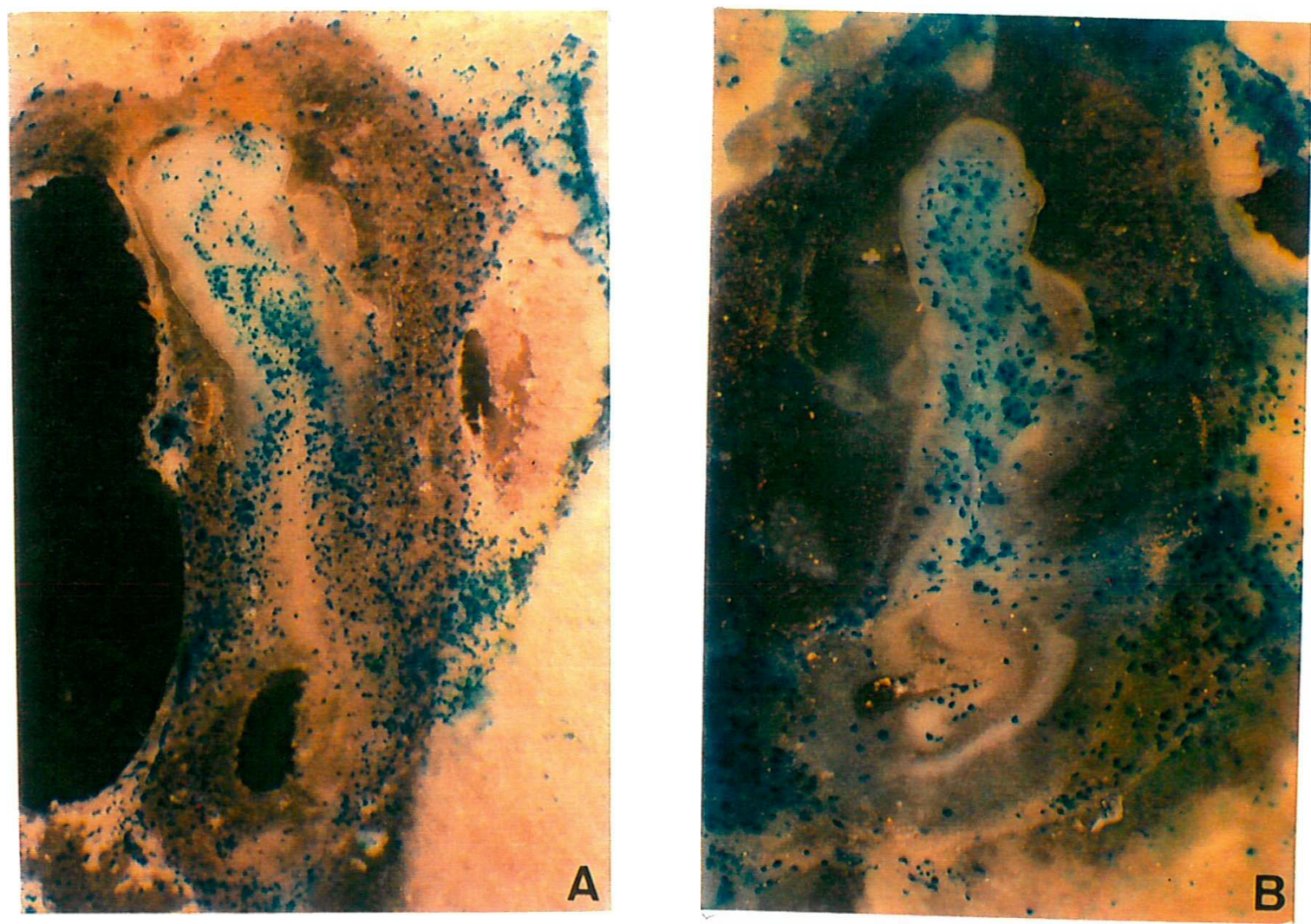

Figura 7. Embriões posicionados a $0,5 \mathrm{~cm}$ do centro do cone de dispersão das partículas e bombardeados com partículas de ouro, 800 psi de hélio, $500 \mathrm{mmHg}$ de vácuo e incubados por 12 horas (A) ou 24 horas (B) após o bombardeamento. A distância percorrida pelo DNA-micropartículas até o embrião foi de $8 \mathrm{~cm}$. (A, $13 X ; B, 19 X)$. 
Tabela 7. Efeito do tempo de incubação na quantidade de embriões descartados, na taxa de sobrevivência e na expressão da $\beta$-gal, em embriões bombardeados com 800 psi de pressão de hélio e $500 \mathrm{mmHg}$.

\begin{tabular}{|c|c|c|c|c|c|}
\hline \multirow[b]{2}{*}{$\begin{array}{l}\text { Tempo de } \\
\text { Incubação } \\
\text { (horas) }\end{array}$} & \multirow[b]{2}{*}{ n } & \multirow[b]{2}{*}{$\begin{array}{l}\text { \% embriões } \\
\text { descartados }\end{array}$} & \multirow[b]{2}{*}{$\begin{array}{l}\text { Taxa de } \\
\text { Sobrevivência } \\
\text { (\%) }\end{array}$} & \multicolumn{2}{|c|}{ Eficiência de Transformação } \\
\hline & & & & $\begin{array}{l}\% \text { embriões com } \\
\text { expressão total }\end{array}$ & $\begin{array}{l}\text { \% embriões com } \\
\text { expressão nas } \\
\text { células do corpo }\end{array}$ \\
\hline 12 & 35 & $22,9(8 / 35)^{1}$ & $29,6(8 / 27)^{2}$ & $100(27 / 27)^{4}$ & $96,3(26 / 27)^{5}$ \\
\hline 24 & 38 & $34,2(13 / 38)$ & $40,0(10 / 25)$ & $100(25 / 25)$ & $100(25 / 25)$ \\
\hline \multicolumn{6}{|c|}{$\begin{array}{l}{ }^{1} \text { No. de embriões degenerados após o bombardeamento } / \text { No. total de embriões bombardeados. } \\
2 \text { No. de embriões com batimento cardíaco após o bombardeamento/No. de embriões bombardeados, } \\
\text { excluindo os descartados. } \\
{ }^{3} \text { Embriões com expressão da } \beta \text {-gal nas células do corpo e/ou no tecido extra-embrionário. } \\
{ }^{4} \text { No. de embriões expressando } \beta \text {-gal/No. de embriões bombardeados, excluindo os descartados. } \\
{ }^{5} \text { No. de embriões expressando } \beta \text {-gal nas células do corpo/No. de embriões bombardeados, excluindo os } \\
\text { descartados. } \\
\text { A distância percorrida pelo DNA-micropartículas até o embrião foi de } 8 \mathrm{~cm} \text {. }\end{array}$} \\
\hline
\end{tabular}

\section{Condições Ótimas}

Para verificar a repetibilidade dos dados gerados com as condições de bombardeamento otimizadas, 70 embriões posicionados a $0,5 \mathrm{~cm}$ do centro do cone de dispersão das partículas e a $8 \mathrm{~cm}$ da membrana carreadora, foram bombardeados com 800 psi de hélio e $500 \mathrm{mmHg}$ de vácuo e, incubados por 24 horas em meio de cultura, antes da deteç̧ão da atividade da $\beta$-gal.

A Tabela 8 mostra os resultados quanto a sobrevivência, número de embriões descartados e expressão da $\beta$-gal. Os resultados mostraram uma diminuição na taxa de sobrevivência, quando comparado com a Tabela 4 (de $40,0 \%$ para $25,4 \%$ ). No entanto, esta diferença não foi estatisticamente significativa $\left(\chi^{2}=1,880^{\text {n.s. }}, G . L .=1\right) . O$ mesmo foi obtido para expressão total e expressão nas células do corpo. Apesar da diminuição dos valores obtidos, de $100 \%$ para 98,5\% (expressão total) e $94,0 \%$ (expressão nas células do corpo), os valores de $\chi^{2}$ obtidos não foram significativos $\left(\chi^{2}=\right.$ $1,003^{\text {n.s. }}$ e $1,560^{\text {n.s. }}$, respectivamente, G.L. $\left.=1\right)$. A maioria dos embriões apresentava batimento cardiaco no momento da fixação, assim como, mais de 100 unidades de expressão nas células do corpo. 
bombardeamento. Estes resultados foram também observados na pele, orelha, figado (Williams et al.,1991) e musculatura esquelética de camundongos (Zelenin et al., 1997), onde os genes introduzidos encontravam-se entre 0,2 e $0,5 \mathrm{~mm}$ de profundidade da superfície do tecido.

\section{GFP Expression}

A técnica otimizada, utilizada para o gene $l a c Z$, foi então aplicada para novos bombardeamentos com o gene GFP. Os resultados obtidos foram muito similares aos obtidos com o da $\beta$-gal. A proteína sintetizada foi detectada, tanto nas células do corpo dos embriões, quanto no tecido extra-embrionário. A quantidade de células expressando a proteína variou de 10 a 100 unidades de expressão (pontos verdes) nas células do corpo dos embriões e no tecido extra-embrionário. A Figure 9 mostra a região mediana dorsal de um embrião, evidenciando a expressão da GFP no tubo neural, nos somitos e no tecido extra-embrionário. Estes resultados já eram prevsitos, uma vez que ambos os genes estão sob o controle do mesmo promotor e foram transferidos sob as mesmas condições de bombardeamento. 

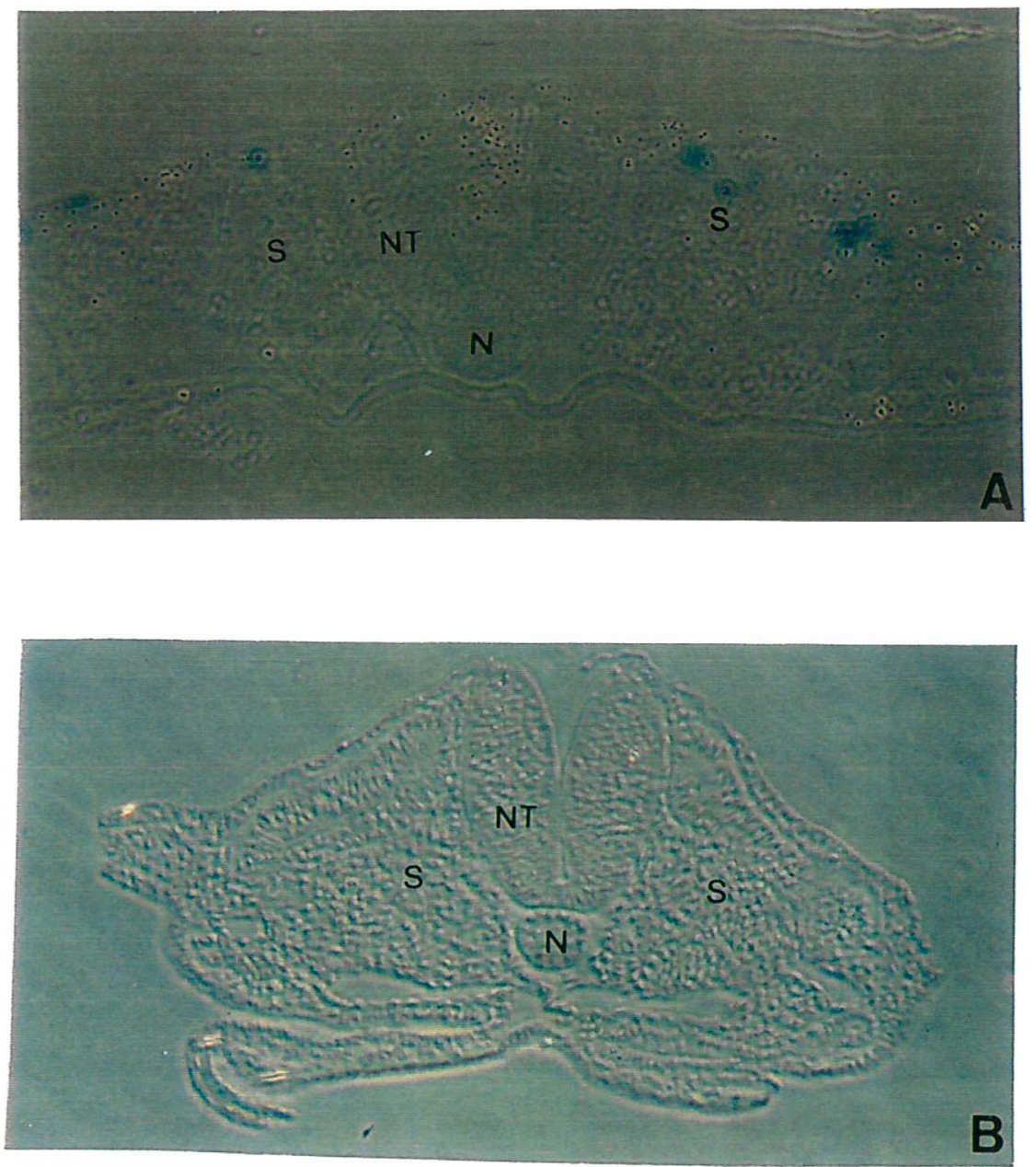

Figura 8. Cortes transversais da região mediana de um embrião bombardeado sob as condições ótimas, evidenciando a expressão da $\beta$-gal nas primeiras camadas dos somitos (A); e de um embrião não bombardeado (B). Abreviações: NT, tubo neural; N, notocorda; S, somitos. (100X). 

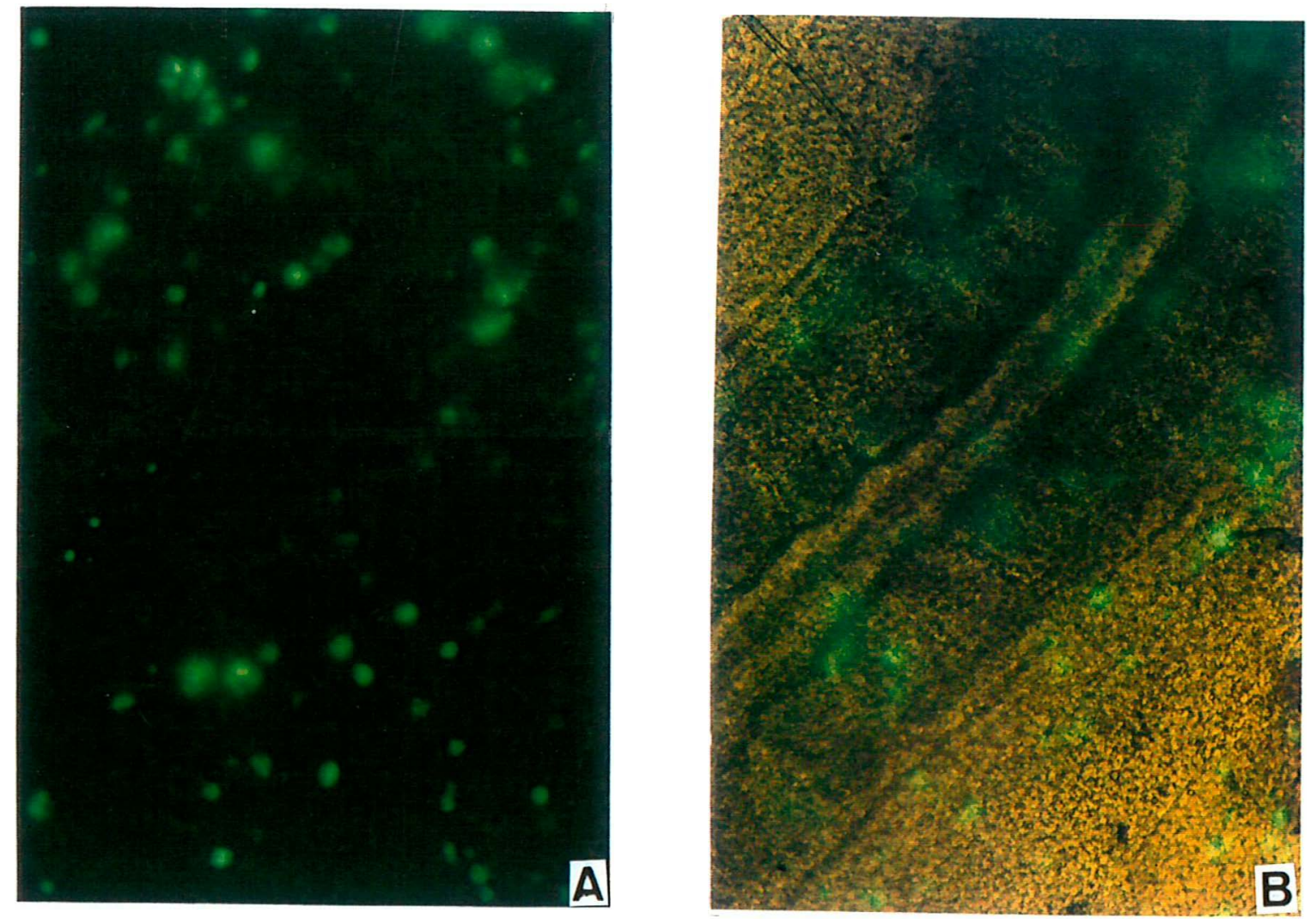

Figura 9. Região mediana de um embrião bombardeado com o gene da GFP, evidenciando tubo neural, somitos e tecido extra-embrionário. A) Somente luz U.V. B) Sobreposição de imagens de luz U.V. e luz visível. Os pontos verdes representam as células expressando GFP. (100X). 


\subsection{DISCUSSÃO}

A transferência de DNA em embriões de galinha, cultivados em meio de cultura, foi obtida com sucesso. O promotor do CMV utilizado resultou em forte expressão por todo o embrião e tecido extra-embrionário e os genes repórteres lacZ e GFP foram facilmente detectados. Uma eficiência de transformação de $98,5 \%$ e uma taxa de sobrevivência de aproximadamente $25 \%$ foram obtidas com: partículas de ouro, distância de $8 \mathrm{~cm}$ percorrida pelo DNA-micropartículas até o embrião, posicionamento dos embriões a $0,5 \mathrm{~cm}$ de distância do centro do cone de dispersão das partículas, 800 psi de gás hélio e $500 \mathrm{mmHg}$ de vácuo. Todos os esforços para aumentar a eficiência de transformação, utilizando pressões de hélio ou vácuo maiores, resultaram em maior expressão, mas menores taxas de sobrevivência foram observadas. $\mathrm{O}$ uso de partículas menores, para reduzir os danos aos embriões, resultou em menores taxas de transformação. O posicionamento dos embriões em relação ao centro do cone de dispersão das partículas foi um importante parâmetro a ser otimizado, visto que embriões posicionados a $2 \mathrm{~cm}$ de distância do centro apresentaram menor eficiência de transformação. Tentativas de aumentar a dispersão das partículas, aumentando a distância percorrida pelas micropartículas até o embrião, resultaram em menor número de células transformadas.

Trabalhos previamente publicados demonstraram que a biolística pode ser utilizada para a transferência de genes em embriões de galinha in ovo (Li et al., 1995; Muramatsu et al., 1997a; Ribeiro et al., 1999). Li et al (1995) transformaram células germinativas primordiais, utilizando uma seringa cirúrgica adaptada e detectaram o gene exógeno em $7,5 \%$ dos embriões bombardeados. Muramatsu et al. (1997a) utilizaram partículas de tungstênio e 285 psi de nitrogênio, obtendo uma eficiência de transformação de $45,8 \%$ e uma taxa de sobrevivência de $42,9 \%$. Entretanto, o número e a intensidade de unidades de expressão foram menores do que os obtidos por Ribeiro et al. (1999). Estes autores obtiveram eficiência de transformação de $68,7 \%$, taxa de sobrevivência de $31,2 \%$ e média de 100 unidades de expressão nas células do corpo dos embriões, utilizando partículas de ouro, $600 \mathrm{mmHg}$ de vácuo e 600 psi de gás hélio. Sob 
as nossas condições, uma maior intensidade e maior número de unidades de expressão foram obtidas. $\mathrm{O}$ fato de os embriões terem sido retirados dos ovos e bombardeados em meio de cultura, sem a presença de uma camada de albumen recobrindo-os, pode ter sido o responsável pela diferença observada entre os nossos resultados e os obtidos pelos outros trabalhos.

Este é o primeiro trabalho demonstrando a possibilidade de introdução e expressão transiente de genes exógenos em embriões de galinha, cultivados em meio de cultura, utilizando a biolística. As condições ótimas de bombardeamento foram obtidas, visando estabelecer um sistema de transformação em galinhas, para o estudo de pesquisas básicas, utilizando um vetor não infeccioso e não replicativo. A expressão transiente de genes in vivo em células somáticas, pode ser adequada ou desejada para muitas aplicações, tais como: estudo da expressão e regulação de genes exógenos, análise de elementos regulatórios da transcrição, expressão de fatores circulantes por um determinado período e caracterização de promotores tecido-específicos. 


\section{CONCLUSÕES GERAIS}

As condições de bombardeamento, associando altas taxas de transformação, máximo número de células transformadas e reduzidos danos aos tecidos bombardeados, foram otimizadas para as duas formas de transferência de genes em embriões de galinha.

No bombardeamento in situ, os melhores resultados foram obtidos com as seguintes condições: partículas de ouro de 1,5 a 3,0 $\mu \mathrm{m}$ de diâmetro, distância de $11 \mathrm{~cm}$ percorrida pelo DNA-micropartículas até o embrião, posicionamento dos embriões a $1 \mathrm{~cm}$ de distância do centro do cone de dispersão das partículas, 600 psi de gás hélio e 600 mmHg de vácuo.

No bombardeamento in vitro, as condições ótimas foram obtidas com: partículas de ouro de 1,5 a 3,0 $\mu \mathrm{m}$ de diâmetro, distância de $8 \mathrm{~cm}$ percorrida pelo DNAmicropartículas até o embrião, posicionamento dos embriões a $0,5 \mathrm{~cm}$ de distância do centro do cone de dispersão das partículas, 800 psi de gás hélio e $500 \mathrm{mmHg}$ de vácuo.

$\mathrm{O}$ bombardeamento in vitro demonstrou maior eficiência de transformação e maior número de células transformadas, do que o bombardeamento in situ. Entretanto, as taxas de sobrevivência obtidas foram similares nas duas formas de transferência gênica.

Os resultados evidenciaram a viabilidade da biolística, como técnica eficiente, para a introdução de genes exógenos em embriões de galinha. 


\section{REFERÊNCIAS BIBLIOGRÁFICAS}

ARAGÃ0, F.J.L.; GROSSI DE SÁ, M.F.; DAVEY,M.R.; BRASILEIRO, A.C.M.; FARIA, J.C.; RECH, E.L. Factors influencing transient gene expression in bean using electrical particle acceleration device. Plant Cell Reports, v. 12, p. 483-490, 1993.

ARAGÃO, F.J.L.; BARROS, L.M.G.; BRASILEIRO, A.C.M.; RIBEIRO,S.G.; SMITH, F.D.; SANFORD, J.C.; FARIA, J.C.; RECH, E.L. Inheritance of foreign genes in transgenic bean (Phaseolus vulgaris L.) co-transformed via particle bombardment. Theoretical and Applied Genetics, v. 93, p. 142-150, 1996.

ARMALEO, D.; YE, G.N.; KLEIN, T.M.; SHARK, K.B.; SANFORD, J.C.; JOHNSTON, S.A. Biolistic nuclear transformation of Saccharomyces cerevisae and other fungi. Current Genetics, v. 17, p. 97-103, 1990.

ATKINSON, P.W.; HINES, E.R.; BEATON, S.; MATTHAEI, K.I.; REED, K.C.; BRADLEY, M.P. Association of exogenous DNA with cattle and inject spermatozoa in vitro. Molecular Reproduction and Development, v. 29, p. 1-5, 1991.

BALDARELLI, R.M.; LENGYEL, J.A. Transient expression of DNA after ballistic introduction into Drosophila embryos. Nucleic Acids Research, v. 18, p. 59035904, 1990. 
BERTLING, W.; HUNGER-BERTLING, K.; CLINE, M.J. Intranuclear uptake and persistent of biologically DNA after electroporation of mammalian cells. Journal of Biochemistry and Biophysics Methods, v. 14, p. 223-232, 1987.

BIRCH, R.G.; FRANKS, T. Development and optimisation of microprojectile systems for plant genetic transformation. Australian Journal of Plant Phisyology, v. 18, p. 453$469,1991$.

BOSSELMAN, R.A.; HSU, R.Y.; BOGGS, T.; HU, S.; BRUSZEWSKI, J.; NICHOLSON, M.; SCHULZ, J.A.; SEMON, K.M.; RUSHELL, W.; STEWART, R.G. Germline transmission of exogenous genes in the chicken. Science, v. 243, p. 533-535, 1989.

BOYNTON, J.E.; GILLHAM, N.W.; HARRIS, E.H.; HOSLER, J.P.; JOHNSON, A.M.; JONES, A.R.; RANDOLPH-ANDERSON, B.L.; ROBERTSON, D.; KLEIN, T.M.; SHARK, K.B.; SANFORD, J.C. Chloroplast transformation of Chlamydomonas with high velocity microprojectiles. Science, v. 240, p. 1534$1537,1988$.

BRAZOLOT, C.L.; PETITTE, J.N.; ETCHES, R..J.; VERRINDER GIBBINS, A.M. Efficient transfection of chicken cells by lipofection, and introduction of transfected blastodermal cells into the embryos. Molecular Reproduction and Development, v. 30, p. 304-312, 1991.

BRISKIN, M.J.; HSU, R.-Y.; BOGGS, T.; SCHULTZ, J.A.; RISHELL, W.; BOSSELMAN, R.A. Heritable retroviral transgenes are highly expressed in chickens. Proceedings of the National Academy of Sciences of the USA, v. 88, p. 1736-1740, 1991.

BURKHOLDER, J.K.; DECKER, J.; YANG, N.S. Rapid transgene expression in lymphocyte and macrophage primary cultures after particle bombardment-mediated gene transfer. Journal of Immunological Methods, v. 165, p. 149-156, 1993. 
CADORET, J.P; BOUlo, V.; GENDREAU, S.; MIALHE, E. Promoters from Drosophila heat shock protein and cytomegalovirus drive transient expression of luciferase introduced by particle bombardment into embryos of the oyster Crassostrea gigas. Journal of Biotechnology, v. 56, p. 183-189, 1997.

CALOS, M.P.; LEBKOWSKI, J.S.; BOTCHAN, M.R. High mutation frequency in DNA transfected into mammalian cells. Proceedings of the National Academy of Sciences of the USA, v. 80, p. 3015-3019, 1983.

CAPECCHI, M.R. High efficiency transformation by direct microinjection of DNA into cultured mammalian cells. Cell, v. 22, p. 479-488, 1989.

CASTRO, F.O.; HERNANDEZ, O.; ULIVER, C.; SOLANO, R.; MILANES, C.; AGUILAR, A.; PEREZ, A.; DE ARMAS, R.; HERRERA, L.; DE LA FUENTE, J. Introduction of foreign DNA into the spermatozoa of farm animals. Theriogenology, v. 34, p. 1099-1110, 1991.

CHANEY, W.G.; HOWARD, D.R.; POLLARD, J.W.; SALLUSTIO, S.; STANLEY, P. High-frequency transfection of $\mathrm{CHO}$ cells using polybrene. Somatic Cellular and Molecular Genetics, v. 12, p. 237-244, 1986.

CHEN, C.; OKAYAMA, H. High-efficiency transformation of mammalian cells by plasmid DNA. Molecular and Cellular Biology, v. 7, p. 2745-2752, 1987.

CHENG, F.M.; JOHO, K. Effect of biolistic particle size on the efficiency of transfection of oocytes in Xenopus ovary tissue. Nucleic Acids Research, v. 22, p. 3265-3266, 1994.

CHENG, L.; ZIEGELHOFFER, P.R.; YANG, N.S. In vivo promoter activity and transgene expression in mammalian somatic tissues evaluated by using particle bombardment. Proceedings of the National Academy of Sciences of the USA, v. 90, p. 4455-4459, 1993. 
DEMENEIX, B.A.; ABDEL-TAWEB, H.; BENOIST, C.; SEUGNET, I.; BEHR, J. P. Temporal and spatial expression of lipospermine-compacted genes transferred into chicken embryo in vivo. BioTechniques, v. 16, p. 496-501, 1994.

DRINKWATER, N.R.; KLINEDINST, D.K. Chemically induced mutagenesis in a shuttle vector with a low-background mutant frequency. Proceedings of the National Academy of Sciences of the USA, v. 83, p. 3402-3406, 1986.

EISENBRAUN, M.D.; FULLER, D.H.; HAYNES, J.R. Examination of parameters affecting the elicitation of humoral immune responses by particle bombardmentmediated genetic immunization. DNA and Cell Biology, v. 12, p. 791-797, 1993.

ETCHES, R.J. Biotechnology and genetic improvement of poultry. In: WORLD'S POULTRY CONGRESS, 20, New Delhi, 1996. Proceedings, vol. 1. New Delhi: World's Poultry Science Association, 1996. p. 295-304.

ETCHES, R.J.; CARSIENCE, R.S.; CLARK, M.E.; FRASER, R.A.; TONER, A.; GIBBINS, A.M.V. Chimeric chickens and their use in manipulation of the chicken genome. Poultry Science, v. 72, p. 882-889, 1993.

EYAL-GILADI, H.; KOCHAV, S. From cleavage to primitive streak formation: a complementary normal table and a new look at the first stage of the development of the chick: I. General morphology. Developmental Biology, v. 49, p. 321-337, 1976.

FELGNER, D.L.; GADEK, T.R.; HOLM, M.; ROMAN, R.; CHAN, H.W.; WENZ, M.; NORTHROP, J.P.; RINGOLD, G.M.; DANIELSEN, M. Lipofection: a highly efficient lipid-mediated DNA-transfection procedure. Proceedings of the National Academy of Sciences of the USA, v. 84, p. 7413-7417, 1987.

FINER, J.J.; VAIN, P.; JONES, M.W.; McMULLEN, M.D. Development of the particle inflow gun for DNA delivery to plant cells. Plant Cells Reports, v. 11, p. 323-328, 1992. 
FITZPATRICK-McELLIGOTT, S. Gene transfer to tumor-infiltrating lymphocytes and other mammalian somatic cells by microprojectile bombardment. Bio/Technology, v. 10, p. 1036-1040, 1992.

FLAMANT, F.; DEMENEIX, B.; BENOIST, C.; MARKOSSIAN-BELIN, S.; SAMARUT, J. Virofection: a new procedure to achieve stable expression of gnes transferred into early embryos. International Journal of Developmental Biology, v. 38, p. $751-757,1994$.

FOX, T.D.; SANFORD, J.C.; McMULLIN, T.W. Plasmids can stably transform yeast mitochondria lacking endogenous mtDNA. Proceedings of the National Academy of Sciences of the USA, v. 85, p. 7288-7292, 1988.

FRASER, R.A.; CARSIENCE, R.S.; CLARK, M.E.; ETCHES, R.J.; VERRINDER GIBBINS, A.M. Efficient incorporation of transfected blastodermal cells into chimeric chicken embryos. International Journal of Developmental Biology, v. 37, p. 381-385, 1993.

FUNGARO, M.H.; RECH, E.L.; MUHLEN, G.S.; VAINSTEIN, M.H.; PASCON, R.C.; QUEIROZ, M.V.; PIZZIRANI-KLEINER, A.A.; AZEVEDO, J.L. Transformation of Aspergillus nidulans by microprojectile bombardment on intact conidia. FEMS Microbiology Letters, v. 125, p. 293-297, 1995.

FURTH, P. A. Gene transfer by biolistic process. Molecular Biotechnology, v. 7, p. 139-143, 1997.

GENDREAU, S.; LARDANS, V.; CADORET, J.P.; MIALHE, E. Transient expression of a luciferase reporter gene after ballistic introduction into Artemia franciscana (Crustacea) embryos. Aquaculture, v. 133, p. 199-205, 1995.

GINSBURG, M.; EYAL-GILADI, H. Primordial germ cells of the young chick blastoderm originate from the central zone of the area pellucida irrespective of embryo-forming process. Development, v. 101, p. 209-219, 1987. 
GORDON, J.W. Transgenic animals. International Review of Cytology, v. 115, p. 171-229, 1989.

GORDON, J.W.; RUDDLE, F.H. Int egration and stable germ line transmission of genes injected into mouse pronuclei. Science, v. 214, p. 1244-1246, 1981.

GORDON, J.W.; SCANGOS, G.A.; PLOTKIN, D.J.; BARBOSA, J.A.; RUDDLE, F.H. Genetic transformation of mouse embryos by microinjection of purified DNA. Proceedings of the National Academy of Sciences of the USA, v. 77, p. 7380$7384,1980$.

GRAHAM, F.L.; VAN DER EB, A.J. A new technique for the assay of infectivity of human adenovirus 5 DNA. Virology, v. 52, p. 456-467, 1973.

HAMBURGER,V.; HAMILTON, H.L. A series of normal stages in the development of the chick embryo. Journal of Morphology, v. 88, p. 49-92, 1951.

HAMMER, R.E.; PURSEL, V.G.; REXROAD, C.E.; WALL, R.J.; BOLT, D.J.; EBERT, K.M.; PALMITER, R.D.; BRINSTER, R.L. Production of transgenic rabbits, sheep and pigs by microinjection. Nature, v. 315, p. 680-683. 1985.

HEISER, W.C. Gene transfer into mammalian cellsby bombardment. Analytical Biochemistry, v. 217, p. 185-196, 1994.

HOCHI, S.; NINOMIYA, T.; MIZUNO, A.; HONMA, M.; YUKI, A. Fate of exogenous DNA carried into mouse eggs by spermatozoa. Animal Biotechnology, v. 1, p. $25-30,1990$.

HOFFMAN, S.L.; DOOLEN, D.L.; SEDEGAH, M.; AGUIAR, J.C.; WANG, R.; MALIK, A.; GRAMZINSKI, R.A.; WEISS, W.R.; HOBART, R.; NORMAN, J.A.; MARGALITH, M; HEDSTROM, R.C. Strategy for development of a preerythrocytic Plasmodium falciparum DNA vaccine for human use. Vaccine, v. 15, p. 842-845, 1997. 
HUGHES, S.H.; KOSIK, E.; FADLY, A.M.; SALTER, D.W.; CRITTENDEN, L.B. Design of retroviral vectors for the insertion of foreign DNA into avian germ line. Poultry Science, v. 65, p. 1459-1462, 1986.

IIDA, A.; SEKI, M.; KAMADA, M.; YAMADA, Y.; MORIKAWA, H. Gene delivery into cultured plant cells by DNA-coated gold particles accelerated by a pneumatic gun. Theoretical and Applied in Genetics, v. 80, p. 813-816, 1990.

IIDA, A.; YAMASHITA, T.; YAMADA, Y.; MORIKAWA, H. Efficiency of particle bombardment- mediated transformation is influenced by cell cycle stage in synchronized cultured cells of tobacco. Plant Physiology, v. 97, p. 1585-1587, 1991.

ITANI, T.; ARRIG, H.; YAMAGUCHI, N.; TADAKUMA, T.; YASUDA, T. A simple and efficient liposome method for transfection of DNA into mammalian cells grown in suspension. Gene, v. 56, p. 267-276, 1987.

ITOH, N.; MIMA, T.; MIKAWA, T. Loss of fibroblast growth factor receptors is necessary for terminal differentiation of embryonic limb muscle. Development, v. 122, p. 291-300, 1996.

JAENISCH, R. Germ line integration of moloney leukemia virus: effect of homozygosity at the m-mulv locus. Cell, v. 12, p. 691-696, 1977.

JAENISCH, R. Transgenic Animals. Science, v. 240, p. 1468-1474, 1988.

JAENISCH, R.; MINTZ, B. Simian virus 40 DNA sequences in DNA of healthy adult mice derived from preimplantation blastocysts injected with viral DNA. Proceedings of the National Academy of Sciences of the USA, v. 71, p. 12501254, 1974.

JIAO, S.; CHENG, L.; WOLF, J.A.; YANG, N.S. Particle bombardment-mediated gene transfer and expression in rat brain tissues. Bio/Technology, v. 11, p. 497-502, 1993. 
JOHNSTON, S.A.; ANZIANNO, P.Q.; SHARK, K.; SANFORD, J.C.; BUTOW, R.A. Mitochondrial transformation in yeast by bombardment with microprojectiles. Science, v. 240, p. 1534-1541, 1988.

JOHNSTON, S.A.; RIEDY, M.; DE VIT, M. J.; SANFORD, J.C.; MCELLIGOTT, S.; WILLIAMS, S. Biolistic transformation of animal tissue. In Vitro Cellular and Developmental Biology, v. 27, p. 11-14, 1991.

KAWAI, S.; NISHIZAWA, M. New procedure for DNA transfection with polycation and dimethyl sulfoxide. Molecular and Cellular Biology, v.4, p.1172-1174, 1984.

KEOWN, W.A.; CAMPBELL, C.R.; KUCHERLAPATI, R.S. Methods for introducing DNA into mamalian cells. Methods in Enzymology, v. 185, p. 527-537, 1990.

KERR, D.E.; FURTH, P.A.; POWELL, A.M.; WALL, R.J. Expression of gene-gun injected plasmid DNA in the ovine mammary gland and in lymph nodes draining the injection site. Animal Biotechnology, v. 7, p. 33-45, 1996.

KLEIN, T.M.; FITZPATRICK-McELLIGOTT, S. Particle bombardment: a universal approach for gene transfer to cells and tissues. Current Opinion in Biotechnology, v. 4, p. 583-590, 1993.

KLEIN, T.M.; WOLF, E.D.; WU, R.; SANFORD, J.C. High-velocity microprojectiles

- for delivering nucleic into living cells. Nature, v. 327, p. 70-73, 1987.

KLEIN, T.M.; FROMM, M.; WEISSINGER, A.; TOMES, D.; SCHAAF, S.; SLETTEN, M.; SANFORD, J.C. Transfer of forein genes into intact maize cells with high-velocity microprojectiles. Proceedings of the National Academy of Sciences of the USA, v. 85, p. 4305-4309, 1988.

KLEIN, T.M.; ARENTZEN, R.; LEWIS, P.A.; \& FITZPATRICK-MCELLIGOTT, S. Transformation of microbes, plants and animals by particle bombardment. Bio/Technology, v. 10, p. 286-291, 1992. 
KRIEGLER, M. Gene transfer and expression: a laboratory manual. New York: W.H. Freeman and Company, 1990. cap. 5, 96-102: DNA Transfer.

KURATA, S.; TSUKAKOSHI, M; KASUYA, T.; IKAWA, Y. The laser method for efficient introduction of foreign DNA into cultured cells. Experimental Cell Research, v. 162, p. 372-378, 1986.

KUWANA, T. Migration of avian primordial germ cells towards the gonadal anlage. Development, Growth and Differentiation, v. 35, p. 237-243, 1993.

LACEY, M.; ALPERT, S.; HANAHAN, D. Bovine papillomavirus genome elicits skin tumours in transgenic mice. Nature, v. 322, p. 609-612, 1986.

LACORTE, C.; ARAGÃO, F.J.L.; VAINSTEIN, M.H.; RECH, E.L. Biobalística. In: TORRES, A.C. \& CALDAS, L.S. (Ed.). Técnicas e aplicações da cultura de tecidos de plantas. ABCTP/CNPH. Brasília. 1996.

LANZA, R.P.; COOPER, D.K.C.; CHICK, W.L. Xenotransplantation. Scientific American, v. 277, p. 54-59, 1997.

LAURIA, A.; GANDOLFI, F. Recent advances in sperm cell mediated gene transfer. Molecular Reproduction and Development, v. 36, p. 255-257, 1993.

L.AVITRANO, M.; CAMAIONI, A.; FAZIO, V.M.; DOLCI, S.; FORACE, M.G.; SPADAFORA, C. Sperm cells as vectors for introducing foreign DNA into eggs: Genetic transformation of mice. Cell, v. 57, p. 717-723, 1989.

LI, Y.; BEHNAM, J.; SIMKISS, K. Ballistic tranfection of avian primordial germ cell in ovo. Trangenic Research, v. 4, p. 26-29, 1995.

LOPATA, M.A.; CLEVELAND, D.W.; SOLLNER-WEBB, B. High level transient expression of a chloramphenicol acetyl transferase gene by DEAE-dextran mediated DNA transfection coupled with a dimethyl sulfoxide or glycerol shock treatment. Nucleic Acids Research, v. 12, p. 5707-5717, 1984. 
LOVE, J.; GRIBBIN, C.; MATHER, C.; SANG, H. Transgenic birds by DNA microinjection. Bio/Technology, v. 12, p. 60-63, 1994.

LUGINBUKE, R.C.; SCHLOTZHAUER, S. D. SAS/STAT ${ }^{\circledR}$ Guide for Personal Computers. $6^{\text {th }}$ ed. SAS Institute Inc., Cary, NC, 1987.

MAHON, K.A.; OVERBEEK, P.A.; WESTPHAL, H. Prenatal lethality in a transgenic mouse line is the result of a chromosomal translocation. Proceedings of the National Academy of Sciences of the USA, v. 85, p. 1165-1168, 1988.

MARTIN, M.J.; PINKERT, C.A. Production of Transgenic Swine. In: PINKERT, C.A. (Ed.) Transgenic Animals Technology: a Laboratory Handbook. Alabama: Academic Press Inc., 1994. cap 11, p. 315-337.

MARZULlO, G. Production of chick chimaeras. Nature, v. 225, p. 72-73, 1970.

McCABE, D.E.; SWAIN, W.F.; MARTINELL, B.J.; CHRISTOU, P. Stable transformation of soybean (Glycine $\max$ ) by particle acceleration. Bio/Technology, v. 6, p. 923-926, 1988.

MENCK, M.C. Seleção de embriões bovinos transgênicos utilizando-se o cDNA da luciferase de vagalume como gene repórter. Ribeirão Preto, 1998. Tese (Doutorado) - Faculdade de Medicina de Ribeirão Preto, Universidade de São Paulo.

MIALHE, E.; MILLER, L.H. Biolistic techniques for transfection of mosquito embryos (Anopheles gambiae). BioTechniques, v. 16, p. 924-931, 1994.

MIMA, T.; UENO, H.; FISCHMAN, D.A.; WILLIAMS, L.T.; MIKAWA, T. Fibroblast growth factor receptor is required for in vivo cardiac myocyte proliferation at early embryonic stages of heart development. Proceedings of the National Academy of Sciences of the USA, v. 92, p. 467-471, 1995. 
MONASTERSKY, G.M. Gene transfer technology: Alternative techniques and applications. In: PINKERT, C.A. (Ed.). Transgenic Animal Technology: A Laboratory Handbook. San Diego: Academic Press, 1994. cap. 6, p. 177-219.

MORIKAWA, H.; IIDA, A.; YAMADA, Y. Transient expression of foreign genes in plant cells and tissues obtained by a single biolistic device (particle-gun). Applied Microbiology in Biotechnology, v. 31, p. 320-322, 1989.

MURAMATSU, T.; MIZUTANI, Y.; OHMORI, Y.; OKUMURA, J. Comparison of three nonviral transfection methods for foreign gene expression in early chicken embryos in ovo. Biochemical and Biophysical Research Communications, v. 230, p. 376-380, 1997a.

MURAMATSU, T.; SHIBATA, O.; RYOKI, S.; OKUMURA, J. Foreign gene expression in the mouse testis by localized in vivo gene transfer. Biochemical and Biophysical Research Communications, v. 233, p. 45-49, $1997 \mathrm{~b}$.

MURAMATSU, T.; IMAI, T.; PARK, H.M.; WATANABE, H.; NAKAMURA, A.; OKUMURA, J. Gene gun-mediated in vivo analysis of tissue-specific repression of gene transcription driven by the chicken ovalbumin promoter in the liver and oviduct of laying hens. Molecular and Cellular Biochemistry, v. 185, p. 27-32, 1998.

NAITO, M.; AGATA, K.; OTSUKA, K.; KINO, K.; OHTA, M.; HIROSE, K.; PERRY, M.M.; EGUSHI, G. Embryonic expression of $\beta$-actin-lacZ hybrid gene injected into the fertilized ovum of the domestic fowl. International Journal of Developmental Biology, v. 35, p. 69-75, $1991 \mathrm{a}$.

NAITO, M.; WATANABE, M.; KINUTANI, M.; NIRASAWA, K.; OISHI, T. Production of quail-chick chimeras by blastoderm cell transfer. British Poultry Science, v. 32, p. 79-86, 1991 b. 
NAITO, M.; SASAKI, E.; OHTAKI, M.; SAKURAI, M. Introduction of exogenous DNA into somatic and germ cells of chickens by microinjection into germinal disc of fertilized ova. Molecular Reproduction and Development, v. 37, p. 167-171, 1994a.

NAITO, M.; TAJMA, A.; YASUDA, Y.; KUWANA, T. Production of germline chimeric chickens, with high transmission rate of donor-derived gametes, produced by transfer of primordial germ cells. Molecular Reproduction and Development, v. 39, p. $153-161,1994 b$.

NAKANISHI, A.; IRITANI, A. Gene transfer in the chicken by sperm-mediated methods. Molecular Reproduction and Development, v. 36, p. 258-261, 1993.

NICOLAU, C.; LEPAPO, A.; SORIANO, P.; FARGETTE, F.; JUHEL, M.F. In vivo expression of rat insulin after intravenous administration of the liposome-entrapped gene for rat insulin I. Proceedings of the National Academy of Sciences of the USA, v. 80, p. 1068-1072, 1983.

NOTARIANNI, E.; EVANS, M.J. Transgenesis and genetic engineering in domestic animals. In: MURRAY, J. A. H. (Ed.) Transgenesis: Application of gene transfer. Chichester: John Wiley \& Sons Ltda, 1992. cap. 10, p. 251-281.

OLIVEIRA, S.C.; ROSINHA, G.M.S.; DE-BRITO, C.F.A.; FONSECA, C.T.; AFONSO, R.R.; COSTA, M.C.M.S.; GOES, A.M.; RECH, E.L.; AZEVEDO, V. Immunological properties of gene vaccines delivery by different routes. Brazilian Journal of Medical and Biological Research, v. 32, p. 207-214, 1999.

PALMITER, R.D.; BRINSTER, R.L.; HAMMER, R.E.; TRUMBAUER, M.E.; ROSENFELD, M.G.; BIRNBERG, N.C.; EVANS, R.M. Dramatic growth of mice that develop from eggs microinjected with metallothionein-growth hormone fusion genes. Nature, v. 300, p. 611-615, 1982. 
PALMITER, R.D.; NORSTEDT, G.; GELINAS, R.E.; HAMMER, R.E.; BRINSTER, R.L. Metallothionein-human GH fusion genes stimulate growth of mice. Science, v. 222, p. 809-814, 1983.

PAPAHADJOPOULOS, D.; VAIL, W.J.; JACOBSON, K.; POSTE, G. Cochleate lipid cylinders: formation by fusion of unilamellar lipid vesicles. Biochimica et Biophysica Acta, v. 394, p. 483-491, 1975.

PETITTE, J.N.; CLARK, M.E.; LIU, G.; GIBBINS, A.M.V. Production of somatic and germ line chimaeras in the chicken by transfer of early blastodermal cells. Development, v. 108, p. 185-189, 1990.

PETITTE, J.N.; CLARCK, M.E.; ETCHES, R.J. Assessment of functional gametes in chickens after transfer of primordial germ cells. Journal of Reproduction and Fertility, v. 92, p. 225-229, 1991.

POTTER, H.; WEIR, L.; LEDER, P. Enhancer-dependent expression of human kappa immunoglobulin genes introduced into mouse pre-B lymphocytes by electroporation. Proceedings of the National Academy of Sciences of the USA, v. 81, p.7161-7165, 1984.

PURSEL, V.G.; REXROAD, C.E. Status of research with transgenic farm animals. Journal of Animal Science. Genetically modified livestock: progress, prospects and issues. v. 71, p. 10-19, 1993. Supplement, 3.

RASMUSSEN, J.L.; KIKKERT, J.R.; ROY, M.K.; SANFORD, J.C. Biolistic transformation of tobacco and maize suspension cells using bacterial cells as microprojectiles. Plant Cell Reports, v. 13, p. 212-217, 1994.

RAZZAQUE, A.; MIZUSAWA, H.; SEIDMAN, M.M. Rearrangement and mutagenesis of a shuttle vector plasmid after passage in mammalian cells. Proceedings of the National Academy of Sciences of the USA, v. 80, p. 30103014, 1983. 
RECH, E.; VAINSTEIN, M.; DAVEY, M. An electrical particle acceleration gun for gene transfer into cells. Technique, v. 3, p. 143-149, 1991.

RECH, E.L.; DE BEM, A.R.; ARAGÃO, F.J.L. Biolistic mediated gene expression in cattle tissues in vivo. Brazilian Journal of Medical and Biological Research, v. 29, p. 1265-1267, 1996.

RIBEIRO, L.A.; AZEVEDO, J.L.; ARAGÃO, F.J.L.; RECH, E.L.; SCHMIDT, G. S.; COUTINHO, L.L. In situ DNA transfer to chicken embryos by biolistic. Genetics and Molecular Biology, 1999 (aceito para publicação).

ROBERTSON, E.; BRADLEY, A.; KUCHN, M.; EVANS, M. Germ-line transmission of genes introduced into cultured pluripotential cells by retroviral vector. Nature, $v$. 323 , p. 445-448, 1986.

ROSENBLUM, C.I.; CHEN, H.Y. In ovo transfection of chicken embryos using cationic liposomes. Transgenic Research, v.4, p. 192-198, 1995.

ROTTMANN, O.J.; ANTES, R.; HOFER, P.; MAIERHOFER, G. Liposome-mediated gene transfer via spermatozoa into avian egg cells. Journal of Animal Breeding and Genetics, v. 109, p. 64-70, 1992.

RUSSEL, J.A.; ROY, M.K.; SANFORD, J.C. Physical trauma and tungsten toxicity reduce the efficacy of biolistic transformation. Plant Physiology, v. 98, p. 1050-1056, 1992.

SALTER, D.W.; CRITTENDEN, L.B. Artificial insertion of a dominant gene for resistance to avian leukosis virus into the germ line of the chicken. Theoretical and Applied Genetics, v. 77, p. 457-461, 1989.

SALTER, D.W.; SMITH, E.J.; HUGHES, S.H.; WRIGHT, S.E.; FADLY, A.M.; WITTER, R.L.; CRITTENDEN, L.B. Gene insertion into chicken germ line by retroviruses. Poultry Science, v. 65, p. 1445-1458, 1986 
SALTER, D.W.; SMITH, E.J.; HUGHES, S.H.; WRIGHT, S.E.; CRITTENDEN, L.B. Transgenic chickens: Insertion of retroviral genes into the chicken germ line. Virology, v. 157, p. 236-240, 1987.

SALTER, D.W.; PAYNE, W.S.; CRITTENDEN, L.B.; FEDERSPIEL, M.J.; PETROPOULOS, C.J.; BRADAC, J.A.; HUGHES, S. Avian leukosis retroviruses and gene transfer into the avian genome. In: ETCHES, R.J.; GIBBINS, A.M.V. (Ed.) Manipulation of the avian genome. Boca Raton, Ann Arbor, London, Tokyo: CRC Press, 1993. cap. 9, p. 135-150.

SANFORD, J.C.; DEVIT, M.J.; RUSSELL, J.A.; SMITH, F.D.; HARPENING, P.R.; ROY, M.K.; JONHSTON, S.A. An improved helium-driven biolistic device. Technique, v. 3, p. 3-16, 1991.

SANFORD, J.C.; SMITH, F.D.; RUSSEL, J.A. Optimizing the biolistic process for different biological applications. Methods in Enzymology, v. 217, p. 483-509, 1993.

SANG, H.; PERRY, M.M. Episomal replication of cloned DNA injected into the fertilized ovum of the hen, Gallus domesticus. Molecular Reproduction and Development, v. 1, p. 98-106, 1989.

SAUTTER, C.; WALDNER, H.; NEUHAUS-URL, G.; GALLI, A.; NEUHAUS, G.; POTRYKUS, I. Micro-targeting: high efficiency gene transfer using a novel approach for the acceleration of microprojectiles. Bio/Technology, v. 9, p. 1080$1085,1991$.

SBICEGO, S.; SCHNAUFER, A.; BLUM, B. Transient and stable transfection of Leishmania by particle bombardment. Molecular Biochemical Parasitology, v. 94, p. 123-126, 1998. 
SCHAEFER-RIDDER, M.; WANG, Y; HOFSCHNEIDER, P.H. Liposomes as gene carriers: efficient transformation of mouse L cells by thymidine kinase gene. Science, v. 215, p. 166-168, 1982.

SCHIEDLMEIER, B.; SCHMITT, R.; MULLER, W.; KIRK, M.M.; GRUBER, H.; MAGES, W. KIRK, D.L. Nuclear transformation of Volvox carferi. Proceedings of the National Academy of Sciences of the USA, v. 91, p. 5080-5084, 1994.

SCHIRMBECK, R.; BOHM, W.; ANDO, K.; CHISARI, F.V.; REIMANN, J. Nucleic acid vaccination primes hepatitis $B$ virus surface antigen-specific cytotoxic $T$ lymphocytes in nonresponder mice. Journal of Virology, v. 69, p. 5929-34, 1995.

SHUMAN, R.M.; SHOFFNER, R.N. Gene transfer by avian retroviruses. Poultry Science, v. 65, p. 1437-1444, 1986.

SIMKISS, K.; ROWLETT, K.; BUMSTEAD, N.; FREEMAN, B.M. Transfer of primordial germ cell DNA between embryos. Protoplasma, v. 151, p. 164-166, 1989.

SMITH, F.D.; HARPENDING, P.R.; SANFORD, J.C. Biolistic transformation of prokaryotes: factors that affect biolistic transfromation of very small cells. Journal of General Microbiology, v. 138, p. 239-248, 1992.

SQUIRES, E.J.; DRAKE, D. Liposome-mediated DNA transfer to chicken sperm cells. Animal Biotechnology, v. 4, p. 71-88, 1993.

SUREAU, C.; ROMET-LEMONNE, J.-L.; MULLINS, J.I.; ESSEX, M.. Production of hepatitis B virus by a differentiated human hepatoma cell line after transfection with cloned circular HBV DNA. Cell, v. 47, p. 37-47, 1986.

SVAB, Z; HAJDUKIEWICZ, P. MALIGA, P. Stable transformation of plastids in higher plants. Proceedings of the National Academy of Sciences of the USA, v. 87 , p. 8526-8530, 1990. 
TAJIMA, A.; NAITO, M.; YASUDA, Y.; KUWANA, T. Production of germ line chimaera by transfer of primordial germ cells in domestic chicken (Gallus domesticus). Theriogenology, v. 40, p. 509-519, 1993.

TAKAGI, S.; KIMURA, M. Low-voltage electric-discharge biolistic device. BioTechniques, v. 23, p. 650-652, 1997.

TANG, D.; DE VIT, M.; JOHNSTON, S.A. Genetic immunization is a simple method for eliciting an immune response. Nature, v. 356, p. 152-154, 1992.

THOMPSON, T.A; GOULD, M.N.; BURKHOLDER, J.K.; YANG, N.S. Transient promoter activity in primary rat mammary epithelial cells evaluated using particle bombardment gene transfer. In Vitro Cellular and Developmental Biology, v. 29A, p. 156-70, 1993.

TONEGUZZO, F. KEATING, A. Stable expression of selectable genes introduced into human hematopoietic stem cells by electric field-mediated DNA transfer. Proceedings of the National Academy of Sciences of the USA, v. 83, p. 34963499, 1986.

ULMER, J.; DONNELLY, J.J.; PARKER, S.E.; RODHES, G.H.; FELGNER, P.; DWARKI, V.J.; GROMKOWSKI, S.H.; DECK, R.R.; DEWITT, C.M.; FRIEDMAN, A.; HAWE, L.A.; LEANDER, K.R.; MARTINEZ, D.; PERRY, H.C.; SHIVER, J.M.; MONTGOMERY, D.L.; LIU, M.A. Heterologous protection against influenza by injection of DNA encodingn a viral protein. Science, v. 259, p. 17451749, 1993.

VAIN, P.; McMULLEN, M.D.; FINER, J. Osmotic treatment enhances particle bombardment-mediated transient and stable transformation in maize. Plant Cell Reports, v. 12, p. 84-88, 1993. 
VAINSTEIN, M. H.; ALVES, S.A.; LIMA, B. D.; ARAGÃO, F.L.; RECH, E.L. Stable DNA transfection in a flagellate trypanosomatid by microparticle bombardment. Nucleic Acids Research, v. 22, p. 3263-3264, 1994.

VICK, L.; LI, Y.; SIMKISS, K. Transgenic birds from transformed primordial germ cells. Proceedings of the Royal Society of London, v. 251, p. 179-182, 1993 a.

VICK, L.; LUKE, G.; SIMKISS, K. Germ-line chimaeras can produce both strains of fowls with high efficiency after partial sterelization. Journal of Reproduction and Fertility, v. 98, p. 637-641, 1993b.

WAGNER, E.F.; COVARRUBIAS, L. STEWART, T.A.; MINTZ, B. Prenatal lethalitus in mice homozygous for human growth hormone gene sequences integrated in the germ line. Cell, v. 35, p. 647-655, 1985.

WALL, R.J. Transgenic Livestock: progress and prospects for the future. Theriogenology, v. 45, p. 57-68, 1996.

WANG, B.; BOYER, J.; SRIKANTAN, V.; UGEN, K., GILBERT, L.; PHAN, C.; DANG, K.; MERVA, M.; AGADJANYAN, M.; NEWMAN, N.; CARRANO, R.; McCALLUS, D.; CONEY, L.; WILLIAMS, W.V.; WEINER, D.B. Introduction of humoral and cellular immune responses to the human immunodeficiency type 1 virus in nonhuman primates by in vivo DNA inoculagion. Virology, v. 211, p. 102$112,1995$.

WATANABE, M.; KINUTANI, M.; NAITO, M.; OCHI, O.; TAKASHIMA, Y. Distribution analysis of transferred donor cells in avian blastodermal chimaeras. Development, v. 114, p. 331-338, 1992.

WATANABE, M.; NAITO, M.; SASAKI, E.; SAKURAI, M.; KUWANA, T.; OISHI, T. Liposome-mediated DNA transfer into chicken primordial germ cells in vivo. Molecular Reproduction and Development, v. 38, p. 268-274, 1994. 
WENTWORTH, B.C.; TSAI, H.; HALLET, J.H.; GONZALES, D.S.; RAJCICSPASOJEVIC, G. Manipulation of avian primordial germ cells and gonadal differentiation. Poultry Science, v. 68, p. 999-1010, 1989.

WILLIAMS, R.S.; JOHNSTON, S.A.; RIEDY, M.; DEVIT, M.J.; McELLIGOTT, S.G.; SANFORD, J.C. Introduction of foreign genes into tissues of living mice by DNAcoated microprojectiles. Proceedings of the National Academy of Sciences of the USA, v. 88, p. 2726-2730, 1991.

WOLFF, J.A.; MALORE, R.W.; WILLIAMS, P.; CHONG, W.; ACSADI, G.; JANI, A.; FELGNER, P.L. Direct gene transfer into mouse muscle in vivo. Science, v. 247, p. 1465-1468, 1990.

WONG, T.K.; NICOLAU, C.; HOFSCHNEIDER, P.H. Appearance of beta-lactamase activity in animal cells upon liposome-mediated gene transfer. Gene, v. 10, p. 87$94,1980$.

YANG, N.S.; BURKHOLDER, J.; ROBERTS, B.; MARTINELL, B.; McCABE, D. In vivo and in vitro gene transfer to mammalian somatic cells by particle bombardment. Proceedings of the National Academy of Sciences of the USA, v. 87, p. 9568$9572,1990$.

YASUDA, Y.; TAJIMA, A.; FUJIMOTO, T.; KUWANA, T. A method to obtain avian germ-line chimaeras using isolated primordial germ cells. Journal of Reproduction and Fertility, v. 96, p. 521-528, 1992.

YE, G.N.; DANIELL, H.; SANFORD, J.C Optimization of delivery of foreign DNA into higher plant chloroplasts. Plant Molecular Biology, v. 15, p. 809-819, 1990.

YOSHIDA, Y.; KOBAYASHI, E.; ENDO, H.; HAMAMOTO, T.; YAMANAKA, T.; FUJIMURA, A.; KAGAWA, Y. Introduction into DNA into rat liver with a handheld gene gun: distribution of the expressed enzyme, $\left[{ }^{32} \mathrm{P}\right] \mathrm{DNA}$, and $\mathrm{Ca}^{2+}$ flux. 
Biochemical and Biophysical Research Communications, v. 234, p. 695-700, 1997.

ZELENIN, A.V.; TITOMITOV, A.V.; KOLESNIKOV, V.A. Genetic transformation of mouse cultured cells with the help of high-velocity mechanical DNA injection. FEBS Letters, v. 244, p. 65-67, 1989.

ZELENIN, A.V.; ALIMOV, A.A.; BARMINTZEV, V.A.; BENIUMOV, A.O; ZELENINA, I.A.; KRASNOV, A.M.; KOLESNIKOV, V.A. The delivery of foreign genes into fertilized fish eggs using high-velocity microprojectiles. FEBS Letters, v. 287, p. $118-120,1991$ a.

ZELENIN, A.V.; ALIMOV, A.A.; TITOMIROV, A.V.; KAZANSKY, A.V.; GOREDETSKY, S.I.; KOLESNIKOV, V.A. High-velocity mechanical DNA transfer of the chloramphenicolacetyl transferase gene into rodent liver, kidney and mammary gland cells in organ explants and in vivo. FEBS Letters, v. 280, p. 94$96,1991 b$.

ZELENIN, A.V.; KOLESNIKOV, V.A.; TARASENKO, O.A.; SHAFEI, R.A.; ZELENINA, I.A.; MIKHAILOV, V.V.; SEMENOVA, M.L.; KOVALENKO, D.V.; ARTEMYEVA, O.V.; IVASCHENKO, T.E.; EVGRAFOV, O.V.; DICKSON, G.; BARANOVAND, V. S. Bacterial $\beta$-galactosidase and human dystrophin genes are expressed in mouse skeletal muscle fibers after ballistic transfection. FEBS Letters, v. 414, p. 319-322, 1997. 